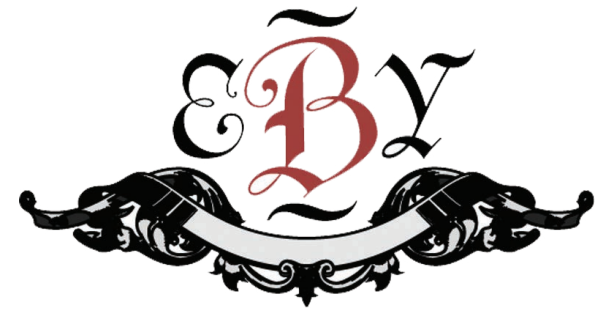

РЕДАКЦІЙНА КОЛЕГІЯ

Головний редактор

Відповідальний секретар

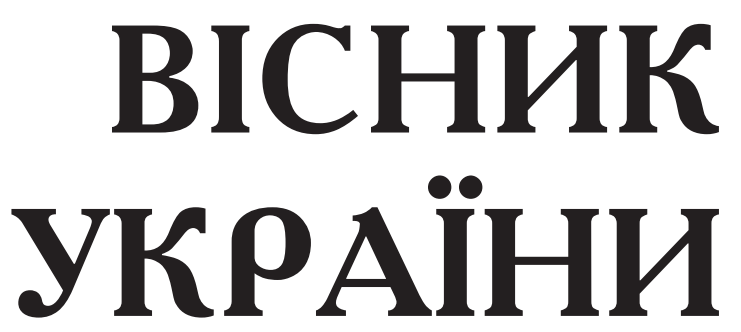

Число 10

2018

\author{
Микола Железняк \\ Олександр Іщенко \\ Сергій Бортник \\ Іван Дзюба \\ Тетяна Добко \\ Станіслав Кульчицький \\ Константин Манолаке (Молдова) \\ Ірина Матяш \\ Любомир Пиріг \\ Роман Сенькусь (Канада) \\ Ярослав Яцків
}

\title{
Адреса редакції:
}

Україна, 01024, м. Київ-4, вул. Терещенківська, 3

e-mail: esu@esu.com.ua

www.evu.encyclopedia.kiev.ua

\section{Засновано у жовтні 2009 року}

2018 (C) Інститут енциклопедичнних досліджень НАН України 


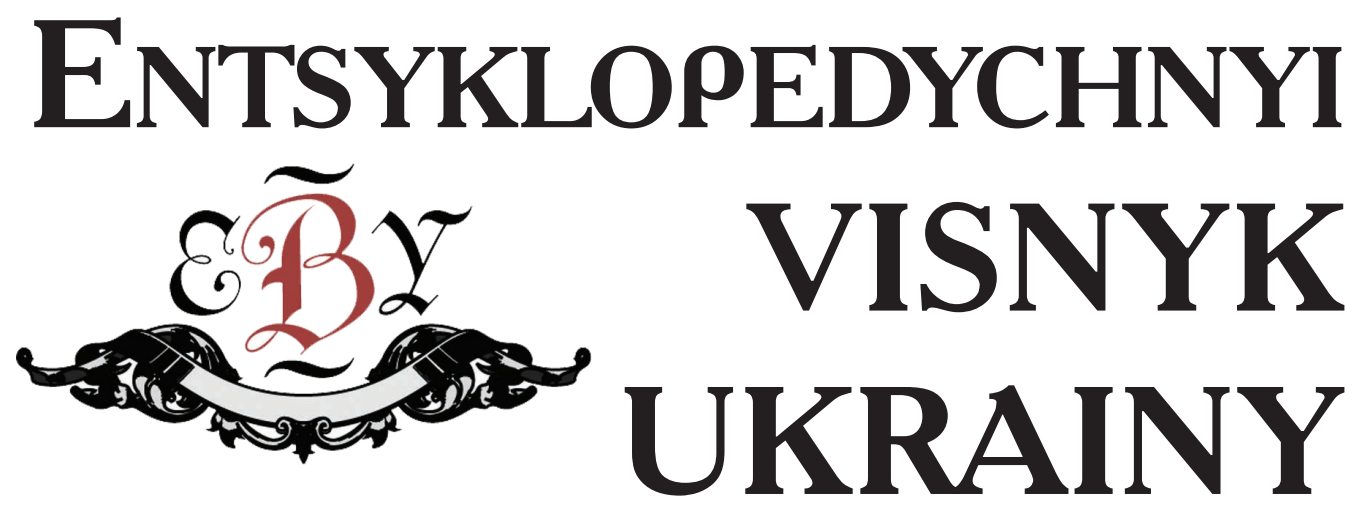

(THE ENCYCLOPEDIA HERALD OF UKRAINE)

Volume 10

EDITORIAL BOARD

2018

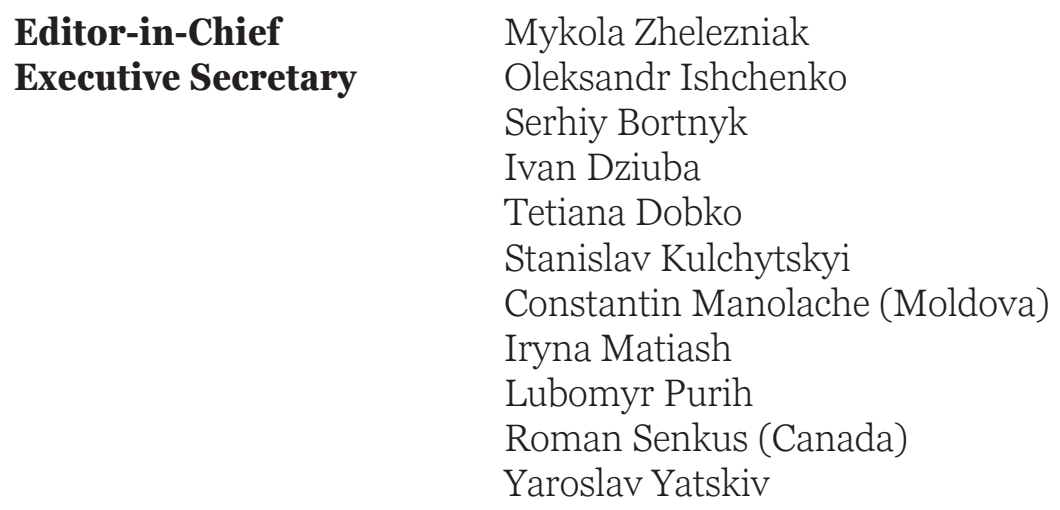

\section{Herald contacts:}

Mykola Zhelezniak
Oleksandr Ishchenko
Serhiy Bortnyk
Ivan Dziuba
Tetiana Dobko
Stanislav Kulchytskyi
Constantin Manolache (Moldova)
Iryna Matiash
Lubomyr Purih
Roman Senkus (Canada)
Yaroslav Yatskiv

Ukraine, 01024, Kyiv-4, 3, Tereshchenkivska str.

e-mail: esu@esu.com.ua

www.evu.encyclopedia.kiev.ua

Founded in October 2009

2018 (C) NASU Institute of Encyclopedic Research 


\section{Спецвипуск}

до 100-річчя Національної академії наук України

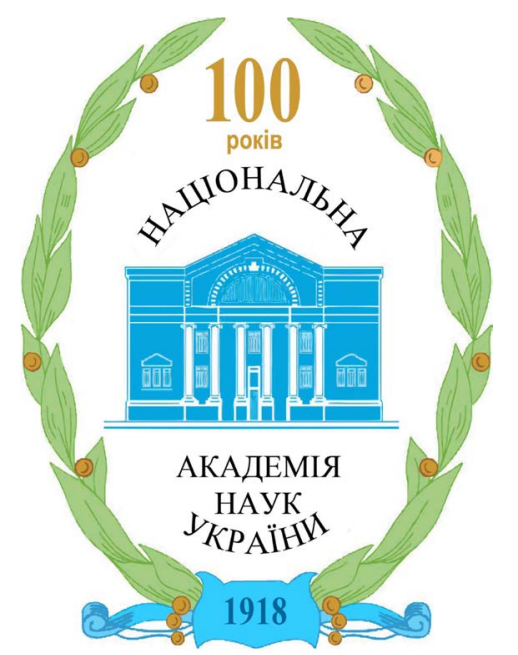

Special volume

devoted to the 100th anniversary of National Academy of Sciences of Ukraine 


\section{MICT \\ Дослідження з енциклопедистики}

Микола Железняк

Енциклопедична справа в Національній академії наук України:

історія та сьогодення..

Олександр Іщенко

Про порушення і захист «екологіі» енциклопедичних знань

(огляд звіту Центру досліджень Європейського парламенту про національні

онлайн-енциклопедії в країнах Європи)..

Володимир Білецький, Геннадій Гайко

Галузева енциклопедія як важливий етап розвитку наукової дисципліни та їі терміносистеми (на прикладі циклу праць із гірництва й геології «Гірнича енциклопедія»)

Микола Железняк, Олександр Іщенко

Академічні онлайн-енциклопедії в контексті розвитку

сучасного інформаційного простору.

\section{Українська енциклопедична справа в термінах}

Матеріали до словника енциклопедичних термінів. .50

Українська енциклопедична справа в подіях

Тетяна Березюк, Оксана Давиденко

Енциклопедична хроніка. .83 


\section{TABLE OF CONTENTS \\ Researches in encyclopedia science}

Mykola Zhelezniak

The encyclopedia publishing in the National Academy of Sciences of Ukraine:

history and present .....

Oleksandr Ishchenko

On violation and protection of the information ecosystem in national encyclopedias (review of the report on national online encyclopedias

in Europe by the European Parliamentary Research Service)

Volodymyr Biletskyi, Hennadii Haiko

Subject specific encyclopedias as an important stage in the development of scientific disciplines and terminology systems (on example of The Mining Encyclopedia as a work in mining industry and geology).

Mykola Zhelezniak, Oleksandr Ishchenko

Academic online encyclopedias

in wiev of the recent information space developing.

\section{Ukrainian encyclopedia science in terms}

Materials to Glossary for Encyclopedia Science .50

\section{Events of the encyclopedia publishing in Ukraine}

Tetiana Bereziuk, Oksana Davydenko

Encyclopedic newsreel. 


\title{
Д ослІджЕння 3 ЕнциклопЕдистики
}

УДК 031:908(477)

\section{ЕНЦИКЛОПЕДИЧНА СПРАВА В НАЦІОНАЛЬНІЙ АКАДЕМІї НАУК УКРАЇНИ: ІСТОРІЯ ТА СЬОГОДЕННЯ*}

\author{
Микола Железняк \\ Інститут енциклопедичних досліджень НАН Украӥни, \\ київ, Украӥна
}

\begin{abstract}
У дослідженні схарактеризовано українську академічну енциклопедичну справу. Увагу акцентовано на особливостях розвитку енциклопедистики в Національній академії наук України: окреслено їі зародження та найважливіші академічні енциклопедичні видання. Проаналізовано спектр енциклопедичних проектів за науковими напрямами та зроблено висновок про значне кількісне переважання представлення знань у форматі енциклопедій суспільно-гуманітарних наук над природничими й технічними. Запропоновано власне бачення подальшого розвитку академічної енциклопедистики.
\end{abstract}

Ключові слова: національна енциклопедія, академічна енциклопедистика, Національна академія наук України, «Енциклопедія Сучасної України», Наукове товариство імені Шевченка.

Українська енциклопедистика, на думку багатьох дослідників, починається 1914 року, коли з'явився перший том синтетичної праці «Украинскій народъ в его прошломъ и настоящемъ », у створенні якої взяли участь най-

* Дослідження оприлюднено на круглому столі «Енциклопедистика в діяльності Національної академії наук України та Наукового товариства імені Шевченка», приуроченого до 100-річчя Національної академії наук України (www.roundtable2018.encyclopedia.kiev.ua). 
визначніші науковці того часу - Федір Вовк, Михайло Грушевський, Агатангел Кримський, Михайло Туган-Барановський, Олександр Русов, Степан Томашівський, Петро Єфименко, Степан Рудницький та багато інших. Хоча зародження традицій створення довідкової літератури, матеріали яких характеризуються енциклопедичністю, сягають ще часів Київської Русі - тоді писали ізборники, найвідомішим серед яких є «Ізборник Святослава» (1073 рік); згодом - України Середніх віків, коли укладали лексикони, зокрема «Лексіконъ славеноршсскій альбо Именъ тлъкованїє» П. Беринди (1627 рік).

Упродовж 20 століття енциклопедистика пройшла етапи становлення й поступу. За радянської доби розвиток енциклопедичної справи пов'язаний, з одного боку, з видавництвом УРЕ (згодом реорганізувалося в Головну редакцію УРЕ (1957-1989), створену 1930 року для підготовки «Української радянської енциклопедії»), що стала найвідомішим енциклопедичним виданням в радянській Україні; з іншого боку - з Науковим товариством імені Шевченка, що здійснювало підготовку національної енциклопедії в еміграції - «Енциклопедії українознавства», а до цього - «Української загальної енцикльопедії», що з'явилася в 3-х томах у 1930-1935 роках.

Розвиток енциклопедичної справи в НАН України починається зі здобуття Україною незалежності, а з нею, як зазначає С. Кульчицький, i «права власності на власну історію » [7, с. 39], це уможливило в 1990-х роках появу ідеї про створення сучасної національної енциклопедії, яка згодом почала реалізовуватися під назвою «Енциклопедія Сучасної України». Так, спочатку Комітет науки і культури при АН України (нині - Український міжнародний комітет з питань науки і культури при НАН України) у співпраці з Науковим товариством імені Шевченка, передусім А. Жуковським, мав на меті до 80-річчя заснування Академіі створити осучаснену версію «Енциклопедії українознавства», яка формально була б їі продовженням - ЕУ-3 (докладніше див.: [3]).

Втім, під час підготовчих робіт стало зрозуміло, що цю ідею реалізувати фактично неможливо, або це дуже компліковано й створить багато незручностей користувачеві, оскільки він повинен обов'язково мати можливість паралельно користуватися «Енциклопедією українознавства», що лише в останні роки стала доступною для українського читача, натомість матеріал, який почала отримувати редакційна колегія ЕУ-3, показав, що можливо створити цілком нову українську неабияк актуальну для утвердження нової держави національну енциклопедію, i «розпорядженням Президї НАН України № 329 від 5 березня 1996 року було сформовано Координаційне бюро з питань підготовки та видання “Енциклопедії Сучасної України” на правах структурного підрозділу Українського міжнародного комітету з питань науки і культури при НАН України» [1, с. 50]. Координаційне бюро згодом реорганізували в Інститут енциклопедичних досліджень НАН України (Постанова Президії НАН України № 121 від 14 квітня 2004 року), основне завдання якого - підготовка «Енциклопедії сучасної України», окрім цього, Інститут було визначено координаційним центром в Україні з питань енциклопедистики. 
Звичайно, варто пам’ятати, що розвиток академічної енциклопедистики тісно пов'язаний передусім з «Українською радянською енциклопедією», адже перше 17-томне видання цієї енциклопедії (за ред. М. Бажана, 19591965) було підготовлено, коли Головна редакція УРЕ перебувала у складі АН УРСР (1957-1974); від 1974 вона була в підпорядковуванні Держкомвидаву УРСР, саме тоді видано друге 12-томне видання «Української радянської енциклопедії» та його російськомовна версія - «Украинская советская энциклопедия». Дослідники зауважують, що друге видання здійснювалося в суттєво гірших політичних умовах, аніж перше. Виведення УРЕ зі складу АН УРСР і диктат партійного керівництва, особливо вороже ставлення до національних енциклопедій М. Суслова, негативно вплинуло на рівень перевиданої УРЕ: багато матеріалів з першого видання не потрапило через цензуру на його сторінки [6].

У період перебування видавництва УРЕ в структурі Академії, окрім «Української радянської енциклопедії», вийшла друком також низка фундаментальних енциклопедичних праць: перше видання «Українського радянського енциклопедичного словника» у 3-х томах (за ред. М. Бажана, 19661968), «Енциклопедія народного господарства УРСР» у 4-х томах (відп. ред. С. Ямпольський, 1969-1972), «Радянська енциклопедія історії України» у 4-х томах (відп. ред. А. Скаба, 1969-1972), перша в світі «Енциклопедія кібернетики» у 2-х томах (відп. ред. В. Глушков, 1973) та інші відомі галузеві й регіональні енциклопедичні одно- й багатотомники, до створення яких так чи інакше були причетні науковці академічних установ. Однак характерною особливістю статей у цих виданнях, особливо суспільного й історичного спрямувань, є заідеологізований підхід у викладенні фактів, оцінці подій чи характеристиці осіб. Загалом у той час енциклопедична справа була радше частиною (складовою) державної політики, ніж фундаментальної науки. Хоча все ж необхідно наголосити на тому, що підготовка зазначених вище енциклопедій з науково-методичної точки зору була на високому рівні, а ідеологічне нашарування стосувалося на той час майже всіх соціогуманітарних наукових напрямів, особливо історичних галузей.

Академічна енциклопедистика за роки незалежності держави здійснила вагомий внесок у подолання інтелектуальної ізольованості, ознайомлення зі світовим досвідом у всіх сферах життя, відтворення повної картини історії, науки, культури. Наголосимо, що особлива роль у цьому належить згаданій вище багатотомній енциклопедії національного значення - «Енциклопедії Сучасної України». Це видання про сучасне політичне, економічне, наукове, культурне та духовне життя в Україні, яке грунутється на кращих традиціях як вітчизняного, так і зарубіжного енциклопедознавства. Серед авторів енциклопедії - відомі у світі дослідники, визнані авторитети у своїй галузі - провідні фахівці НАН України, галузевих академій, науковці вищої школи, мистецтвознавці, краєзнавці, видатні науковці діаспори. Зауважимо, що натепер вона складається з 20-ти томів і є найбільшим в Україні енциклопедичним 
виданням, оскільки кількісно вже переважає найбільшу донедавна 17-томну «Українську радянську енциклопедію». Ще одна важлива особливість цієї енциклопедії - представлення ї̈ в мережі Інтернет як мультимедійної онлайненциклопедї ${ }^{1}$.

Великим науково-культурним досягненням стало видання різними академічними установами низки галузевих енциклопедій, серед яких фундаментальна «Енциклопедія історії України» в 10-ти томах (відп. ред. В. Смолій, 2003-2013), «Шевченківська енциклопедія» в 6-ти томах (відп. ред. М. Жулинський, 2012-2015), «Юридична енциклопедія» в 6-ти томах (відп. ред. Ю. Шемчушенко), «Політична енциклопедія» (відп. ред. Ю. Левенець, 2012), «Енциклопедія етнокультурознавства» (відп. ред. Ю. Римаренко, 2000-2002), 4 видання енциклопедії «Українська мова» (відп. ред. В. Русанівський, 2004-2013), 5 томів «Української музичної енциклопедї» (відп. ред. Г. Скрипник), «Філософський енциклопедичний словник» (відп. ред. В. Шинкарук), «Астрономічний енциклопедичний словник» (відп. ред. І. Климишин, А. Корсунь, 2003), 2-томний енциклопедичний словник «Фізика твердого тіла» (відп. ред. В. Бар'яхтар, 1996-1998). Нещодавно опубліковано «Українську нафтогазову енциклопедію» (відп. ред. В. Іванишин, 2016) та «Українську фольклористичну енциклопедію» (відп. ред. В. Сокіл), а також перші томи «Франківської енциклопедї̈ в 7-ми томах (відп. ред. М. Жулинський, 2016) та перший том енциклопедії «Країни світу і Україна», запланованої в 5-ти томах (відп. ред. А. Кудряченко, 2017). Загальний перелік енциклопедій НАН України (зокрема й тих, що підготовлено в радянські часи) наводимо окремо (див. додаток).

Варто також зауважити про участь різних установ НАН України у підготовці низки українських енциклопедичних видань, що публікувалися поза Академією. Серед них - енциклопедіі, підготовлені Науковим товариством імені Шевченка, наприклад, енциклопедія «Наукове товариство імені Шевченка» (відп. ред. О. Купчинський) - за участі Інституту енциклопедичних досліджень НАН України; проект «Гірнича енциклопедія» (кер. В. Білецький, містить «Тлумачний гірничий словник», «Гірничий енциклопедичний словник» і «Малу гірничу енциклопедію», 1998-2013) - за участі Інституту геохімії, мінералогії та рудоутворення імені М. Семененка НАН України, Інституту фізико-органічної хімї й вуглехімії імені Л. Литвиненка НАН України. А також енциклопедіі, підготовлені різними компетентними видавництвами, наприклад, «Українська літературна енциклопедія» (відп. ред. I. Дзеверін, М. Жулинський, 1988-1995) - за участі Інституту літератури імені Т. Шевченка НАН України; «Енциклопедія Львова» у 4-х томах (відп. ред. А. Козицький, І. Підкова, 2007-2010) - за участі Інституту українознавства імені I. Крип'якевича НАН України та Інституту народознавства НАН

\footnotetext{
${ }^{1}$ Режим доступу: http://esu.com.ua
} 
України; «Екологічна енциклопедія» у 3-х томах (відп. ред. А. Толстоухов, 2006-2008) - за участі Інституту ботаніки імені М. Холодного та Інституту зоології імені І. Шмальгаузена; «Українська дипломатична енциклопедія» у 2-х томах (відп. ред. Л. Губерський, 2004) - за участі Інституту держави i права імені В. Корецького. Нині фахівців НАН України залучено до створення універсальної вітчизняної багатотомної енциклопедії - «Великої української енциклопедії, яку готує державна наукова установа «Енциклопедичне видавництво» .

Згадаємо також і про те, що чимало українських видань, що творяться поза академічними інститутами, часто застосовують принципи й методичні рекомендації, запропоновані для укладання академічних енциклопедій. Наприклад, у передмові до «Тернопільського енциклопедичного словника» зазначено, що його готують на засадах укладання «Енциклопедії Сучасної України».

На основі згаданого вище переліку пропонуємо кількісний аналіз академічних енциклопедій. Загальна кількість енциклопедичних видань, підготовлених установами НАН України, - 49. Із них відповідно до типологїі ${ }^{2}$ енциклопедичних видань (рис. 1):

- загальні енциклопедії - 3 (ЕСУ, УРЕ, УРЕС)

- галузеві енциклопедичні видання - 46.

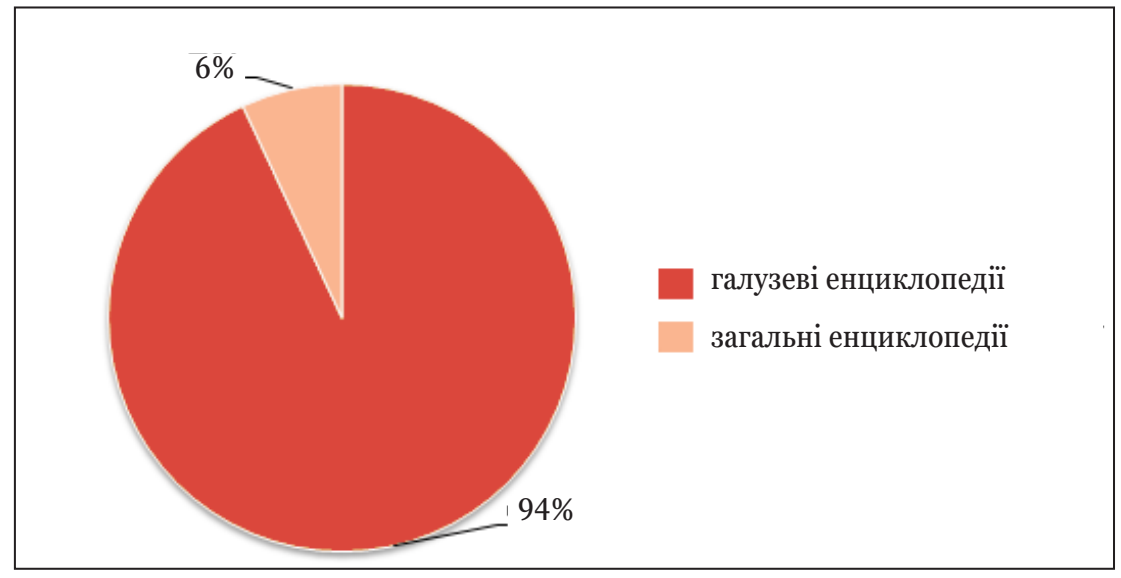

Рис. 1. Типологічний розподіл енциклопедичних видань у НАН України

Галузеві енциклопедії репрезентують такі наукові напрями (рис. 2):

- суспільно-гуманітарні науки - 35 видань,

- фізико-математичні науки - 6 видань,

- хімічно-біологічні науки - 5 видань.

\footnotetext{
2 Питання типології українських енциклопедичних видань висвітлено в: [9].
} 
Для порівняння: представлення наукових напрямів установами НАН України (згідно з даними - [2]; рис. 3):

- секція суспільних і гуманітарні наук - 35 установ,

- секція фізико-технічних і математичних наук - 75 установ,

- секція хімічних та біологічних наук - 43 установи.

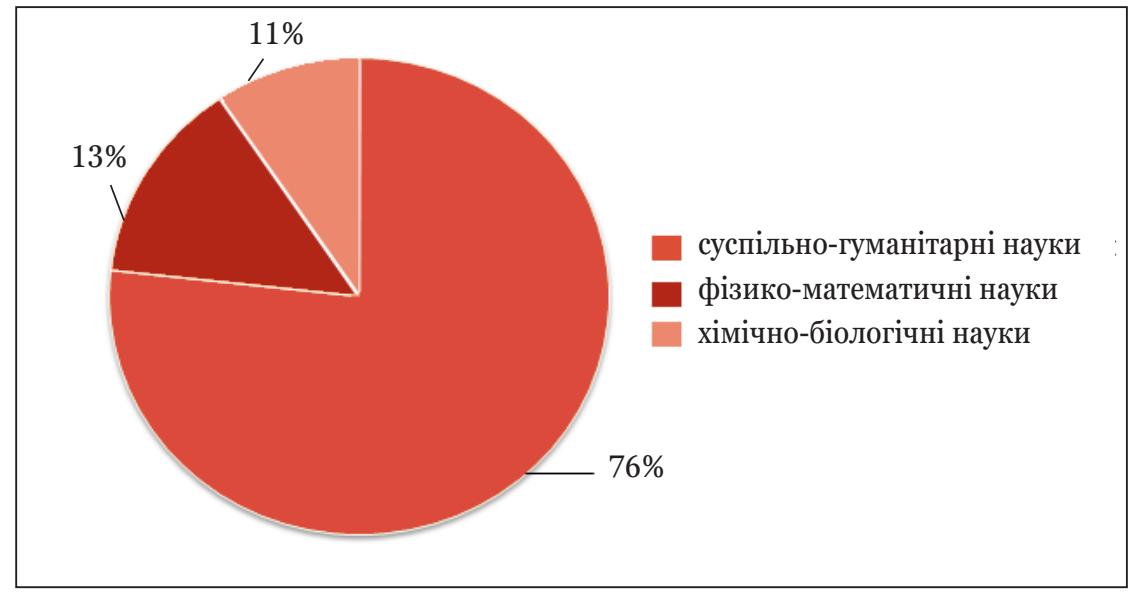

Рис. 2. Розподіл енциклопедичних видань за науковими напрямами (в межах НАН України)

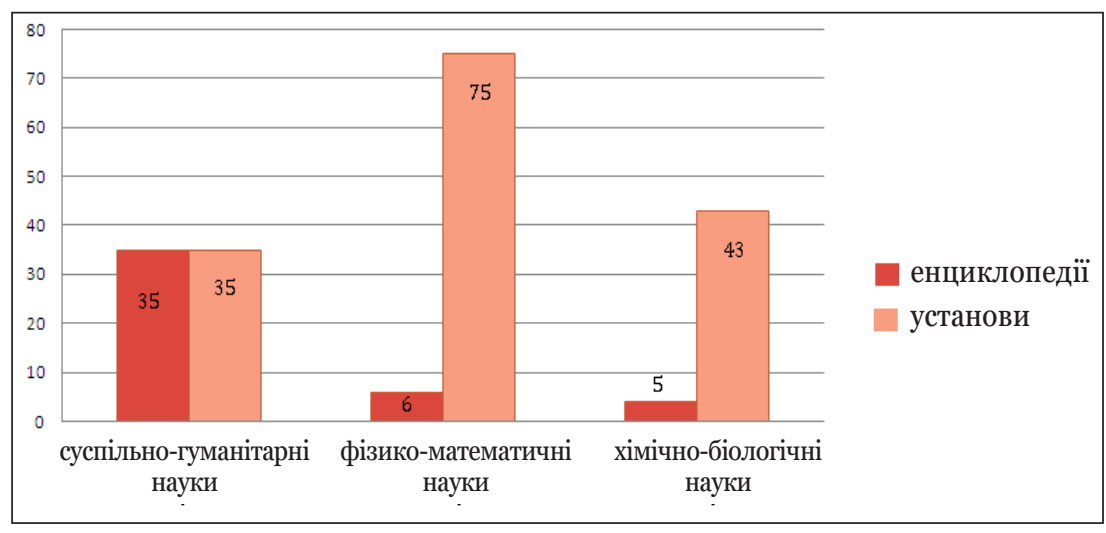

Рис. 3. Представлення академічних знань в енциклопедичному форматі

Викладені статистичні дані наштовхують на певні міркування.

1. Бажано, щоб кожна чи декілька установ НАН України, що відповідають за науковий напрямок, підготували видання, що представлятиме наукові досягнення й здобутки академічних працівників і загалом науковців України, які є фахівцями відповідної галузі знань, у форматі енциклопедії. 
Такі видання, окрім наукового значення, будуть дієвим засобом популяризації в суспільстві науки загалом і НАН України зокрема.

2. Як видно з поданих діаграм, у форматі енциклопедичних видань представлені передусім наукові знання, що створюються установами суспільно-гуманітарного профілю, однак попри порівняно велику їхню кількість, відзначаємо відсутність грунтовних енциклопедичних видань про: економіку, соціологію, всесвітню історію, археологію, сходознавство, мистецтвознавство тощо. Можемо констатувати, що перед українською енциклопедистикою лежить неоране поле не лише в галузі природничих чи технічних наук, а й гуманітраних. До речі, нам є, з кого брати приклад: у сусідній Білорусі виданнями енциклопедичного формату охоплено майже всі сфери життя (див.: [5]).

3. Очевидно, найбільшим надбанням досвіду підготовки таких видань, як «Енциклопедія Сучасної України», «Енциклопедія українознавства» чи «Українська радянська енциклопедія», є практика залучення до написання енциклопедичних статей відомих науковців, наукових колективів, установ, товариств тощо.

4. У контексті залучення вчених до створення енциклопедичних видань варто згадати про важливість проведення попередньої роботи: затвердження концептуальних і методичних засад, на яких буде створюватися енциклопедичне видання, укладання сло́вника, узгодження низки питань із підготовки матеріалів. Зазвичай редакція видає методичні рекомендації, розробляє схеми чи зразки статей, укладає бібліографічні покажчики й часто започатковує публікування періодичного чи неперіодичного збірника (журналу, вісника, бюлетеня). «3 метою налагодження тісних зв’язків із читачами та для ширшого залучення наукових установ і громадських організацій до підготовки статей УРЕ редбюро енциклопедії на своєму засіданні 23 січня 1931 р. ухвалило рішення створити “Бюлетень УРЕ” - про це говориться в першому номері цього видання (див.: [4]). Н. Черниш зауважує, що на його сторінках мали на меті оприлюднювати інструктивні та науково-методичні матеріали, призначені для авторів і редакторів енциклопедії [10, с. 153].

Подібне інформаційне видання мала й редакція «Енциклопедії українознавства» - «Вісті із Сарселю», в якому обговорювалися біжучі проблеми створення ЕУ, провадили дискусії, друкували відгуки та оцінки як окремих статей, так і енциклопедії загалом. Ці видання є важливим і цікавим джерелом відомостей про творення українських енциклопедій.

Започаткував такий часопис й Інститут енциклопедичних досліджень НАН України під назвою «Енциклопедичний вісник України». Окрім цього, для створення «Енциклопедії Сучасної України» важливим було попереднє напрацювання методичних інструкцій щодо підготовки статей, які спочатку існували для вузького кола осіб (редакторів, авторів), а згодом їх опубліковано науковим виданням (див.: [8]). Нині в авторській базі ЕСУ - понад 4000 осіб, які брали чи беруть участь у підготовці статей для енциклопедії, 
велика частина з яких - науковці, зокрема працівники академічних інститутів. Загалом редакція енциклопедіі має налагоджені контакти з переважною більшістю науково-дослідних установ Академії, а також закладів вищої освіти, обласних, районних і міських державних адміністрацій, творчих спілок, музеїв, спортивних товариств, громадських організацій. Широка консолідація фахівців над створенням національної енциклопедії - це запорука успішності видання, умова його об'єктивності й науковості.

\section{ДОДАТОК \\ (академічні енциклопедичні видання)}

\section{Секція суспільних і гуманітарних наук}

1. Енциклопедія етнокультурознавства: У 2 ч. / Редкол.: Ю. Римаренко, Ю. Шемшученко та ін. та ін.; Інститут держави і права ім. В. Корецького НАН України Київ, 2000-2002.

2. Енциклопедія історії України: У 10 т. / Редкол.: В. Смолій та ін.; Інститут історії України НАН України. Київ, 2003-2013.

3. Енциклопедія м. Часів Яр / Редкол.: В. Гірчак та ін. ; Центр пам'яткознавства НАН України. Часів Яр; Київ, 2010.

4. Енциклопедія морських катастроф України: затонулі пам'ятки античності, середньовіччя і нової, історії: залишки міст і поселень, військові кораблі, цивільні судна, авіа- та бронетехніка / Укл.: С. Воронов; Інститут археології НАН України. Київ, 2008.

5. Енциклопедія народного господарства Української РСР: У 4 т. / Відп. ред. С. Ямпольський. Київ: Головне видавництво УРЕ АН УРСР, 19691972.

6. Енциклопедія Сучасної України: В 30-ти т. Т. 1-20 / Редкол.: І. Дзюба, А. Жуковський, М. Железняк та ін.; Інститут енциклопедичних досліджень НАН України. Київ, 2001-2018.

7. Звід пам'яток історії та культури України / Редкол.: В. Смолій, Г. Боряк та ін.; Інститут історії України НАН України. Київ, 1999-2018;

8. Дипломатія сучасної України: Енциклопедичний довідник / Редкол.: М. Железняк, І. Дзюба та ін.; Інститут енциклопедичних досліджень НАН України. Київ, 1997.

9. Історія міст і сіл Української РСР: В 26 т. / Гол. ред. П. Тронько. Київ: Головна редакція УРЕ АН УРСР, 1968-1973.

10. Країни світу і Україна: У 5 т. Т. 1: Північна Європа. Західна Європа. Південна Європа / Редкол.: А. Кудряченко, А. Бульвінський та ін.; Інститут всесвітньої історії НАН України. Київ: Фенікс, 2017.

11. Культура: Ілюстрована енциклопедія України / Укл.: М. Попович. Київ, 2010. 
12. Мала енциклопедія етнодержавознавства / Редкол.: Ю. Римаренко та ін.; Інститут держави і права ім. В. Корецького НАН України. Київ, 1996.

13. Мала енциклопедія міжнародного права / Редкол.: Ю. Бошицький та ін.; Київський університет права НАН України. Київ, 2013.

14. Мала енциклопедія теорії держави і права / Редкол.: Ю. Бошицький та ін.; Київський університет права НАН України. Київ, 2010.

15. Мала енциклопедія українського народознавства / Редкол.: С. Павлюк та ін.; Інститут народознавства НАН України. Львів, 2007.

16. Микола Костомаров: Віхи життя і творчості: Енциклопедичний довідник / Редкол.: В. Смолій, Ю. Пінчук, О. Ясь; Інститут історії України НАН України. Київ, 2005.

17. Наукове товариство імені Шевченка. Енциклопедія. Т. 1-3 / Редкол.: О. Купчинський та ін.; НТШ, Інститут енциклопедичних досліджень НАН України. Львів, 2012-2016.

18. Політична енциклопедія / Редкол.: Ю. Левенець, Ю. Шаповал та ін.; Інститут політичних і етнонаціональних досліджень ім. І. Кураса. Київ, 2012.

19. Політологічний енциклопедичний словник: У 2-х вид. / Редкол.: Ю. Шемчушенко, В. Бабкін та ін.; Інститут держави і права ім. В. Корецького НАН України. Київ, 1997-2004.

20. Радянська енциклопедія історії України: У 4 т. / Відп. ред. А. Скаба. Київ: Головне видавництво УРЕ АН УРСР, 1969-1972.

21. Тарас Шевченко: енциклопедичний онлайн-портал / Інститут літератури ім. Т. Шевченка НАН України; Інститут телекомунікацій і глобального інформаційного простору НАН України. Київ, 2014.

22. Україна в міжнародних відносинах: Енциклопедичний словник-довідник. Вип. 1-4 / Інститут історії України НАН України. Київ, 2009-2013.

23. Українська літературна енциклопедія: У 5 т. Т. 1-3 / Редкол.: І. Дзеверін, М. Жулинський та ін.; Інститут літератури ім. Т. Шевченка НАН України Київ, 1988-1995.

24. Українська мова: Енциклопедія: У 4-х вид. / Редкол.: В. Русанівський та ін.; Інститут української мови НАН України; Інститут мовознавства ім. О. Потебні НАН України К., 2004-2013.

25. Українська музична енциклопедія: У 6 т. Т. 1-5 / Редкол.: Г. Скрипник та ін.; Інститут мистецтвознавства, фольклористики та етнології імені М. Рильського НАН України Київ, 2006-2018.

26. Українська радянська енциклопедія: У 17 т. / За ред. М. Бажана. Київ: Головне видавництво УРЕ АН УРСР, 1959-1965.

27. Українська фольклористична енциклопедія / Гол. ред. В. Сокіл; Інститут народознавства НАН України. Львів, 2018. 
28. Український енциклопедичний кінословник / Редкол.: С. Безклубенко та ін.; Інститут мистецтвознавства, фольклористики та етнології ім. М. Рильського НАН України. Київ, 2006.

29. Український радянський енциклопедичний словник: У 3 т. / За ред. М. Бажана. Київ: Головне видавництво УРЕ АН УРСР, 1966-1968.

30. Філософський енциклопедичний словник: А-Я / Редкол.: В. Шинкарук та ін.; Інститут філософії ім. Г. Сковороди НАН України. Київ, 2002.

31. Франківська енциклопедія: У 7 т. Т. 1 / Редкол.: М. Жулинський, Є. Нахлік та ін.; Інститут Івана Франка НАН України Львів, 2016.

32. Художня культура західних і південних слов'ян (XIX - початок XX століття): Енциклопедичний словник / Редкол.: Г. Скрипник та ін.; Інститут мистецтвознавства, фольклористики та етнології ім. М. Рильського НАН України. Київ, 2006.

33. Шевченківська енциклопедія: У 6 т. / Редкол.: М. Жулинський та ін.; Iнститут літератури ім. Т. Шевченка. Київ, 2012-2015.

34. Шевченківський словник: У 2 т. Редкол.: Є. Кирилюк та ін.; Інститут літератури ім. Т. Шевченка. Київ, 1976-1978.

35. Юридична енциклопедія: у 6 т. / Редкол.: Ю. Шемшученко та ін.; Інститут держави і права ім. В. Корецького НАН України. Київ, 19982004.

\section{Секція фізико-технічних і математичних наук}

1. Астрономічний енциклопедичний словник / Редкол.: І. Климишин, А. Корсунь та ін.; ГАО НАН України, Львівський національний університет. Київ; Львів, 2003.

2. Енциклопедія кібернетики: В 2 т. / Редкол.: В. Глушков та ін.; Інститут кібернетики АН УРСР. Київ: Головне видавництво УРЕ, 1973.

3. Імена України в Космосі: Науково-енциклопедичне видання / Редкол.: I. Вавилова, В. Плачинда; ГАО НАН України. Київ, 2003.

4. Надтверді абразивні матеріали в механообробці: Енциклопедичний довідник / Редкол.: М. Новіков та ін.; Інститут надтвердих матеріалів ім. В. Бакуля НАН України. Київ, 2013.

5. Неорганическое материаловедение: Энциклопедическое издание / Сост.: Г. Гнесин и др.; Институт проблем материаловедения им. И. Францевича НАН Украины. Киев, 2007-2008.

6. Физика твердого тела: Энциклопедический словарь: В 2 т. / Редкол.: В. Барьяхтар и др. Киев: НАН Украины, 1996-1998. 


\section{Секція хімічних і біологічних наук}

1. Ихтиопатологическая энциклопедия / Редкол.: О. Давидов та ін.; Інститут зоології ім. І. Шмальгаузена НАН України. Київ, 2000.

2. Мінералогічна енциклопедія України: онлайн-енциклопедія (Українська мінералопедія) / За ред. О. Пономаренка; Інститут геохімії, мінералогії та рудоутворення ім. М. Семененка НАН України. Київ, 2016

3. Паразитологія та патологія риб: Енциклопедичний словник-довідник / Редкол.: А. Гаєвська та ін.; Інститут проблем міцності ім. Г. Писаренка НАН України; Інститут біології південних морів імені О. Ковалевського НАН України. Київ, 2004.

4. Українська енциклопедія лісівництва: У 2 т. / Редкол.: С. Генсірук та ін.; НТШ, НАН України. Львів, 1999-2007.

5. Українська нафтогазова енциклопедія / Редкол.: В. Іванишин та ін.; Інститут геології і геохімії горючих копалин НАН України. Львів, 2016.

\section{ЛITЕРАТУРА}

1. Бойко Ю. Інститут енциклопедичних досліджень Національної академії наук України: історія створення і діяльність // Гілея: науковий вісник. 2016. Вип. 109. С. 50-55.

2. Довідкова інформація. Статистичні дані // Національна академія наук України у 2017 році: аналітичний звіт. К.: Академперіодика, 2018. С. 40.

3. Железняк М. Енциклопедія Сучасної України: історія створення // Наука України у світовому інформаційному просторі: зб. наук праць. Вип. 12. Київ, 2015. С. 115-127.

4. Завдання бюлетеню // Бюлетень УРЕ. 1931. № 1. С. 1-4.

5. Імя Петруся Броўкі. Беларуская Энцыклапедыя. Мінск, 2005.

6. Ісаєвич Я., Железняк М. Енциклопедія // Енциклопедія Сучасної України Т. 9 / Редкол.: І. Дзюба, А. Жуковський, М. Железняк та ін.; Інститут енциклопедичних досліджень НАН України. Київ, 2009. С. 2016-209.

7. Кульчицький С. Вітчизняна історія в енциклопедичному форматі // Енциклопедичний вісник України. 2009. Ч. 1. С. 39-46.

8. Методичні засади створення паперових і електронних енциклопедичних видань: посібник / Відп. ред. М. Железняк; Інститут енциклопедичних досліджень. Київ: Академперіодика, 2015.

9. Українські енциклопедії: типологія, стиль, функції: монографія / Відп. ред. Я. Яцків; Інститут енциклопедичних досліджень НАН України. Київ, 2018.

10. Черниш Н. Нариси з історії української енциклопедичної справи. Львів: Піраміда, 2018. 


\title{
THE ENCYCLOPEDIA PUBLISHING IN THE NATIONAL ACADEMY OF SCIENCES OF UKRAINE: HISTORY AND PRESENT
}

\author{
Mykola Zhelezniak \\ NASU Institute of encyclopedic research, \\ Kyiv, Ukraine
}

The study describes the academic encyclopedias of Ukraine. The main attention is paid to the peculiarities of the development of the encyclopedia publishing at the National Academy of Sciences of Ukraine: its origins and the most important academic encyclopedias are outlined. The spectrum of encyclopedic projects is analyzed by the scientific branches and the conclusion is drawn about the significant advantage of social sciences and humanities over others in the contex of presenting knowledge in encyclopedic format. Some vision of further development of the encyclopedia publishing in Academy is proposed.

Keywords: National Encyclopedia, Academic Encyclopeditia publishing, National Academy of Sciences of Ukraine, Encyclopedia of Modern Ukraine, Shevchenko Scientific Society.

\section{REFERENCES}

Boiko, Y. (2016). Instytut entsyklopedychnykh doslidzhen Natsionalnoi akademii nauk Ukrainy: istoriia stvorennia i diialnist. Hileia: naukovyi visnyk, 109, 50-55 (in Ukrainian).

Chernysh, N. (2018). Narysy z istorii ukrainskoi entsyklopedychnoi spravy. Lviv: Piramida (in Ukrainian).

Dovidkova informatsiia. Statystychni dani. Natsionalna akademiia nauk Ukrainy u 2017 rotsi: analitychnyi zvit. (2018). Kyiv: Akademperiodyka (in Ukrainian).

Imia Petrusia Brovki. Belaruskaia Entsyklapediia. (2005). Minsk (in Belarusian).

Isaievych, Y., Zhelezniak M. (2009). Entsyklopediia. In Entsyklopediia suchasnoi Ukrainy. (Vol. 9, pp. 206-209). Kyiv: NASU Institute of Encyclopedic Research (in Ukrainian).

Kulchytskyi, S. (2009). Vitchyzniana istoriia v entsyklopedychnomu formati. Entsyklopedychnyi visnyk Ukrainy, 1, 39-46 (in Ukrainian).

Yatskiv, Y. (Ed.). (2018). Ukrainski entsyklopedii: typolohiia, styl, funktsii. Kyiv: NASU Institute of Encyclopedic Research (in Ukrainian).

Zavdannia biuleteniu. (1931). Biuleten URE, 1, 1-4 (in Ukrainian).

Zhelezniak, M. (2015). Entsyklopediia suchasnoi Ukrainy: istoriia stvoren- 
nia. Nauka Ukrainy u svitovomu informatsiinomu prostori, 12, 115-127 (in Ukrainian).

Zhelezniak, M. (Ed.). (2015). Metodychni zasady stvorennia paperouykh i elektronnykh entsyklopedychnykh vydan. Kyiv: Akademperiodyka (in Ukrainian). 


\title{
ПРО ПОРУШЕННЯ І ЗАХИСТ «ЕКОЛОГЇ̈ ЕНЦИКЛОПЕДИЧНИХ ЗНАНЬ (ОГЛЯД ЗВІТУ ЦЕНТРУ ДОСЛІДЖЕНЬ СВРОПЕЙСЬКОГО ПАРЛАМЕНТУ ПРО НАЦІОНАЛЬНІ ОНЛАЙН-ЕНЦИКЛОПЕДІї В КРАЇНАХ GВРОПИ)*
}

\author{
Олександр Іщенко \\ Інститут енциклопедичних досліджень НАН України, \\ Київ, Украӥна
}

\begin{abstract}
Дослідження присвячено питанням екосистеми енциклопедичних знань. Річ у тім, що довідкову інформацію нині дедалі частіше використовують як засіб маніпуляції громадською свідомістю (з політичних, ідеологічних, економічних тощо міркувань), що яскраво помітно на прикладі онлайн-енциклопедій з вільним доступом до редагування розміщеної інформації, зокрема таких, як «Вікіпедія». Статтю побудовано на основі опису аналітичного звіту про онлайн-енциклопедії в країнах Європи, який підготували фахівці Європейського парламенту.
\end{abstract}

Ключові слова: онлайн-енциклопедія, національна енциклопедія, енциклопедичні знання, інформаційна екологія, інформаційний вандалізм.

Процес глобалізації, що охоплює економічну, політичну, соціальну та духовну сфери життя соціуму, інтенсивно впливає на суспільство загалом та на рівень свідомості людей зокрема, створюючи нові умови та виміри дійсності, які треба осягати і до яких необхідно адаптуватися. Глобалізація й істотний розвиток інформаційних технологій спричинив підвищення рівня поширення інформації, доступу до неї та їі рецепцію. Унаслідок цього нині в інтернет-просторі активно розвивається інформаційне суспільство, породжуючи нові явища, серед яких виділимо такі (взаємопов’язані), як інформаційне середовище,

\footnotetext{
*Дослідження оприлюднено на круглому столі «Енциклопедистика в діяльності Національної академії наук України та Наукового товариства імені Шевченка», приуроченого до 100-річчя Національної академії наук України (www.roundtable2018.encyclopedia.kiev.ua).
} 
інформаційний вандалізм та інформаційна екологія. Щоправда, треба зауважити, що відповідні терміни з'явилися ще в 20 столітті, коли сучасних технологій ще не існувало, але вже тоді провадили дослідження проблем впливу інформації на людину (в межах філософських, біологічних чи комп'ютерних наук). Наприклад, інформаційну екологію виокремили в окрему наукову дисципліну, вважаючи її такою, що вивчає закономірності впливу інформації на формування й функціонування людини, людських спільнот, людства загалом, а також на здоров’я як стан психічного й соціального добробуту [4].

Сьогодні ж - у час комунікаційно-інформаційних технологій - поняття інформаційної екології набуло дещо іншого значення, хоча й продовжує перебувати в загальних рамках наведеного вище тлумачення. Нині їі розуміють передусім як захист людей від спотвореної інформації, що здатна впливати на свідомість людських груп, закріплюючи в них певні (хибні) уявлення, переконання, стереотипи. Інформацію можуть спотворювати навмисне або ж ні (випадково чи помилково). Із навмисним спотворенням інформації, зокрема яке здійснюється систематично, пов'язане явище інформаційного впливу - «організоване цілеспрямоване застосування спеціальних інформаційних засобів і технологій для внесення змін у свідомість населення (корекція поведінки) та / або інформаційно-технічну інфраструктуру об’єкта» [5]. На думку окремих фахівців, питання інформаційної екології, яке сприймається як щось менш істотне порівняно з біологічною екологією, насправді, в сучасному світі потребує набагато більш активної уваги, зокрема й дослідження її як «доктрини виживання людства в умовах інформаційного середовища» [1, с. 6].

Поряд з інформаційною екологією та інформаційним впливом співіснує поняття інформаційної безпеки, тобто стану чи процесу, коли інформацію захищено від несанкціонованих дій (отримання, використання, оприлюднення, руйнування, внесення змін, ознайомлення, копіювання чи знищення). Серед несанкціонованих дій варто виокремити так званий інформаційний вандалізм, що безпосередньо стосується сфери енциклопедистики. Це явище характерне для онлайн-енциклопедій вільного типу, тобто таких, у яких відкрито доступ до редагування наявних матеріалів та додавання нових. Найвідомішою вільною онлайн-енциклопедією $€$ «Вікіпедія». За визначенням, розміщеним на одній з їі сторінок [8], вандалізмом в енциклопедичній галузі називають шкідницьке додавання, вилучення чи зміну вмісту з метою, що суперечить місії створення енциклопедії. Фундаментальна мета підготовки будь-якої енциклопедії - це передусім чітко структуроване й лапідарне подання достовірних (точних, перевірених), об’єктивних (з урахуванням різних точок зору) та неупереджених (тих, що не спрямовані проти когось або чогось; незаангажованих) знань. Відтак опрацювання інформації, внаслідок чого вона набуває ознак оманливості - неточності, суб'єктивності чи упередженості - $є$ інформаційним вандалізмом.

У зв'язку з тим, що «Вікіпедія» $є 1$ ) енциклопедією ${ }^{1}$ (тобто жанром літера-

${ }^{1}$ Варто зауважити, що багато хто з дослідників не погоджується з визначенням «Вікіпедії» як енциклопедії в традиційному розумінні цього терміна у зв’язку з їі спе- 
тури, який вважають еталонним виданням і надійним джерелом інформаціі) та 2) найбільш популярною у світі онлайн-енциклопедією, інформаційний вандалізм у ній дедалі частіше стає методом цілеспрямованого інформаційного впливу - поширенню у широкі маси людей певних суджень, пропагандистських ідей, нав'язування політичних, економічних чи релігійних переконань. Інакше кажучи, «Вікіпедія», яку читають мільйони людей і якій довіряють, є зручним майданчиком для проведення інформаційних війн, протистоянь і конфліктів.

Закономірно, що інформаційний захист у «Вікіпедії» - одна з найпоширеніших проблем у наукових дослідженнях з інтернет-енциклопедистики. 3'ясовано, що наслідки інформаційного вандалізму у «Вікіпедії можуть бути відносно швидко усунені [2, с. 156]. Та незважаючи на це, читач все одно не захищений від того, що на час ознайомлення з інформацією вона «екологічна», а не «вандалізована».

Викривлення інформації, дезінформація тощо, тобто все те, що порушує екологію інформаціі (знань) - ці явища в сучасному інформаційному просторі (мас-медіа, соціальні мережі, відкриті довідкові ресурси) набули загрозливого зростання. Будь-яку інформацію нині варто перевіряти кілька разів перед тим, як вважати їі дійсною. За окремими даними, 80\% всієї інформаціі, якою володіє людина, отримано із джерел, що можуть зазнавати інформаційного впливу: «Треба усвідомити той факт, що ми дізнаємося про світ здебільшого не безпосередньо; переважно йдеться про світ, повідомлений через інформаційні засоби. Те, що людина сьогодні знає, щонайбільше на 20\% грунтується на їі власному досвіді, а 80\% передається через пресу, радіо й телебачення» [6, с. 144]. Інформаційні впливи та війни «здатні обернутися для людства тотальною катастрофою, оскільки, як інструмент політики, інформаційна війна означає існування одного суспільства ціною виключення іншого, за рахунок знищення культурних цінностей та свідомості членів цього суспільства» [4, с. 28].

Отже, порушені питання виходять за межі наукових зацікавлень, позаяк стосуються безпеки (нехай і інформаційної) кожної людини та людських спільнот (від соціальних груп до народів / націй). Саме тому Європейський парламент, один із найпотужніших законодавчих органів у світі, виявив занепокоєння станом інформаційної екосистеми в глобальному інтернет-просторі. Зокрема, у зв'язку з дедалі частішим використанням довідкової інформації у «Вікіпедії» з метою маніпулювання громадською свідомістю, Центр досліджень Європейського парламенту поставив за мету дослідити в країнах Європи енциклопедичні інтернет-видання, які виявляють стійкість інформаційної екосистеми, тобто такі, знання в яких, передусім соціогуманітарного характеру, можна вважати екологічними (неспотвореними, надійними) та захищеними від деструктивного інформаційного впливу. Вибірку таких джерел

цифічними особливостями, натомість пропонує вважати ї окремим новим видом (жанром) довідкових джерел - вікіпедією. 
сформували національні електронні енциклопедії, підготовлені фаховими (науковими) колективами. Результати дослідження представлено в аналітичному звіті під назвою «Europe’s online encyclopaedias» [7].

Зазначена розвідка подає основні онлайн-енциклопедії в європейських країнах, характеризує рівень їхньої популярності серед читачів, порівнюючи з «Вікіпедією», аналізує доступність їх в Інтернеті. Прикметно, що в розділі про Україну згадано онлайн-версії «Енциклопедії Сучасної України» (ЕСУ), «Енциклопедії історії України» (ЕІУ) та українську «Вікіпедію». У цьому розділі, зокрема, так описано про ЕСУ:

Електронна енциклопедія ЕСУ містить близько 100 тисяч статей; ï створено на основі багатотомної друкованої «Енциклопедї Сучасної України» - сучасноїнаціональноїенциклопедиї, що надає відомості про Украйну від початку $20 \mathrm{~cm}$. донині, формуючи цілісний образ краӥни з акцентом на висвітленні історичних подій, установ, організацій та видатних осіб. ЕСУ укладає Інститут енциклопедичних дослідженъ Національної академї наук України, який для підготовки енциклопедичних матеріалів згуртував понад 1000 експертів - авторитетних фахівців із тих чи інших галузей знань, передусім провідних учених Національної академиї наук Украйни та Наукового товариства імені Шевченка.

Окрім загальних відомостей про «Енциклопедію Сучасної України», у звіті схарактеризовано рейтинг иї сайту, який визначає його позицію стосовно інших у країні, засвідчуючи цим самим доступність / популярність інтернетресурсу (автори використовують рейтинг статистичної служби Alexa Internet; він формується на основі обчислення комбінації середнього значення щоденних унікальних користувачів і приблизної кількості переглядів сторінок сайту за останній місяць в країні). За цим показником, як стверджується в дослідженні, сайт ЕСУ займає 6322 позицію в Україні (станом на 10 січня 2018 року). Водночас зауважимо, що на сьогодні (червень 2018 року) рейтинг сайту ЕСУ від служби Alexa Internet ${ }^{2}$ підвищився до 4300 позиції в українському інтернет-просторі. Варто також зазначити, що відповідно до даних іншої статистичної служби (Google Analytics) в середньому за місяць сайт енциклопедії ЕСУ відвідує понад 70000 тисяч унікальних користувачів, які при цьому переглядають понад 100000 сторінок енциклопедії. Звісно, порівняно з українськомовною «Вікіпедією», яка входить до десятки найбільш рейтингових сайтів нашої країни та займає десяте місце серед усіх мовних розділів «Вікіпедії» в Європі [7, с. 12], онлайнову ЕСУ використовують набагато рідше.

Автори звіту докладно характеризують і власне «Вікіпедію», зокрема досліджують різні ії аспекти, через які екосистема наявних у ній знань перманентно зазнає деструктивного втручання. Яскравим прикладом слугує опис ситуації в Туреччині: через загрозу національній безпеці уряд заборонив функціонування «Вікіпедії» в країні. 3 недовірою до ресурсу поставився й

\footnotetext{
${ }^{2}$ Режим доступу: http://www.alexa.com/siteinfo/esu.com.ua
} 
уряд Китаю, який у 2017 році запропонував створити китайську національну енциклопедію, найнявши для цього понад 20 тисяч осіб персоналу в сподіванні, що нове джерело довідкових знань буде популярнішим і, головне, надійнішим в країні за «Вікіпедію».

Описуючи «Вікіпедію» як майданчик інформаційної війни, автори звіту згадали й про Україну. Зокрема, навели приклад інформаційної битви в одній російськомовній статті, де подано інформацію про збиття у 2014 році в Донецькій області авіалайнера рейсу MH17 за маршрутом Амстердам Куала-Лумпур: конфліктним формулюванням було пояснення причини авіакатастрофи - спочатку в статті зазначалося, що літак було збито ракетною установкою «Бук» терористами самопроголошеної ДНР; згодом це твердження відредагували, внаслідок чого причетними до падіння літака стали українські солдати. У розвідці підкреслено, що внесені зміни здійснено з IP-адреси однієї з російських державних медіакомпаній.

У звіті згадано про ще одну вільну онлайн-енциклопедію - «Метапедію»³, інформація в якій «екологічно» небезпечна. Ї̈ позиціоновано як альтернативну енциклопедію; вона має різні мовні розділи, технічно діє за принципами «Вікіпедії», функціонуючи на «вікі»-технології. Енциклопедія публікує статті про культуру, мистецтво, науку, філософію і політику. Однак, особливість цього джерела енциклопедичних знань у тому, що статті «забарвлені» ультраправими оцінками, пропагандуючи таким чином у Європі нацизм, расизм і шовінізм. Наведені вище факти щодо стану інформаційної безпеки у «Вікіпедії й спонукали авторів розвідки з’ясувати, чи існують у країнах Європи загальні онлайненциклопедії, екосистема знань у яких лишається стійкою. Аналіз європейських національних онлайн-енциклопедій на предмет доступності «екологічних» знань для суспільства призвів до поділу країн на 4 групи (див. рис. 1).

Перша група: країни, що не мають базової активної (у якій матеріали актуалізовані) національної онлайн-енциклопедії (Бельгія, Білорусь, Боснія і Герцеговина, Данія, Ірландія, Мальта, Румунія, Сербія, Словаччина, Словенія, Туреччина, Фінляндія, Чорногорія). Одна з особливостей цієї групи в тому, що жителі відповідних країн (окремих із них) послуговуються енциклопедіями інших мов. Наприклад, бельгійці користуються французькими, німецькими чи голландськими джерелами; шведомовні фіни - шведськими джерелами. Ще одна особливість - мовні розділи відповідних країн у «Вікіпедії» мають низьку кількість статей. Отже, такі країни як правило послуговуються чужою (інших країн) довідковою інформацією.

Друга група: енциклопедії, у яких доступ до національних онлайн-енциклопедій обмежений - користування енциклопедіями вимагає реєстрації та / або оплати для доступу до всіх матеріалів (Велика Британія, Естонія, Греція, Португалія). Третя група: країни, у яких доступ до національних онлайн-енциклопедій цілковито платний (Франція, Іспанія, Німеччина, Нідерланди,

\footnotetext{
${ }^{3}$ Режим доступу: http://www.metapedia.org
} 
Швеція). Четверта група: країни, у яких доступ до національних онлайненциклопедій вільний - без реєстрації і оплати (Україна, Польща, Австрія, Болгарія, Норвегія. Чехія, Хорватія, Італія, Латвія, Литва, Росія).

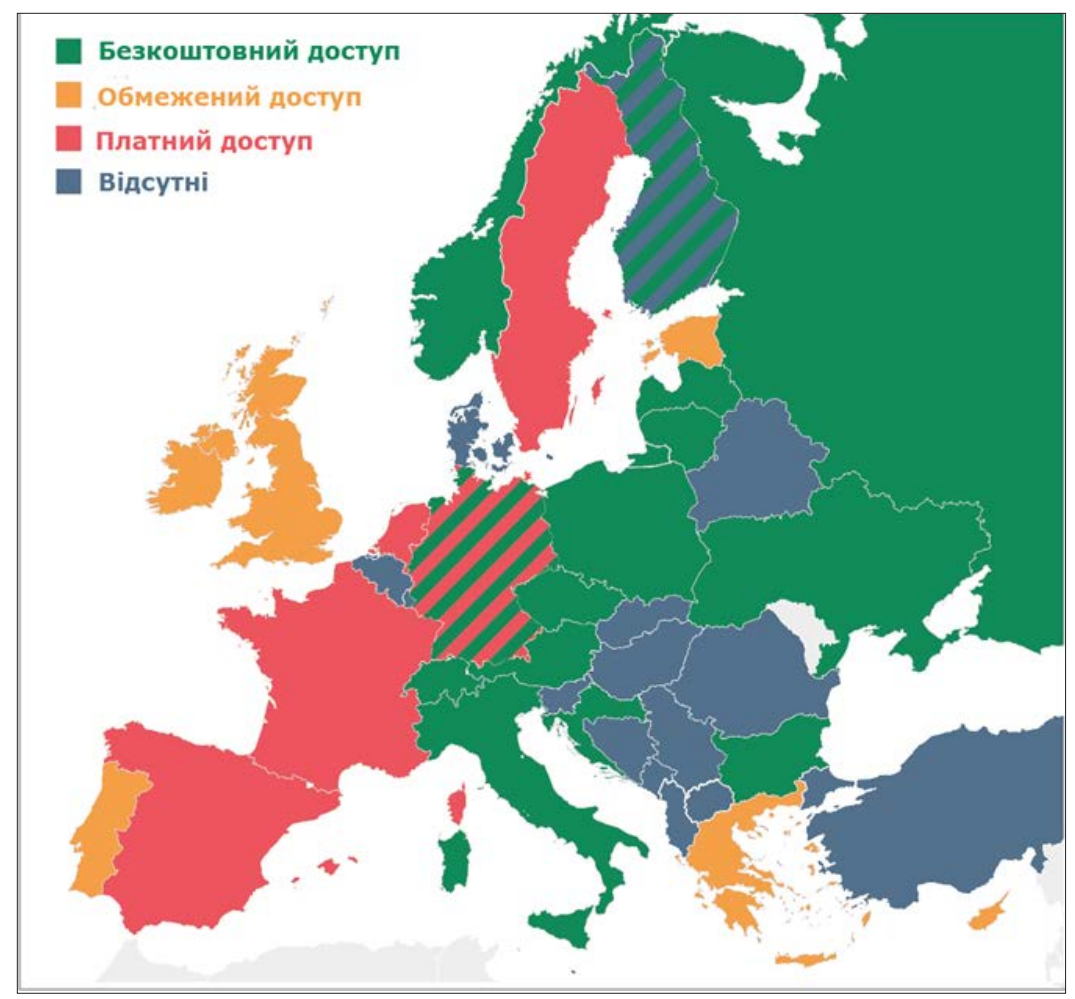

Рис. 1. Особливості доступу до енциклопедичної інформації в країнах Європи (на прикладі національних онлайн-енциклопедій)

Аналіз рейтингу сайтів національних онлайн-енциклопедій та показників обсягу інформації в них (за кількістю статей) засвідчив про значно нижчу їх популярність та менший обсяг порівняно з «Вікіпедією. Привертає увагу й той факт, що в багатьох країнах користувачі «Вікіпедії» віддають перевагу розділу англійською, а не рідною мовою. Схожа тенденція і в Україні: щоправда, у нас перевагу віддають не англомовному, а російськомовному розділу.

У звіті резюмується, що загалом Європа має широку енциклопедичну палітру; іiі представляють різні енциклопедичні традиції, а знання в європейських енциклопедіях відображають культурну спадщину держав, їхні цінності, ознаки самобутності й ідентичності. Автори схиляються до тієї ідеї, що доступ до знань про кожну країну серед європейської спільноти має бути вільним, передусім із мовної точки зору (йдеться про те, що національним енциклопедіям не вистачає полімовної опції, оскільки переважна більшість із них - одномовні). 
Далі з метою ознайомлення наведемо перелік європейських національних онлайн-енциклопедій.

\section{Австрія:}

- онлайн-енциклопедія «Austria-Forum» ${ }^{4}$. Створено на основі електронної словникової бази «Annotierbare Elektronische Interaktive Österreichische Universallexikon», яка у свою чергу - на базі «Österreich-Lexikon» («Австрійський глосарій»).

\section{Велика Британія:}

- онлайн-енциклопедія «Encyclopaedia Britannica»5. Онлайн-енциклопедія від 2010 року є продовженням найвідомішої у світі енциклопедії «Британіка», яка почала друкувати томи ще у 18 столітті.

\section{Білорусь:}

- оцифрована енциклопедія «Беларуская Энцыклапедыя». Оцифровану копію 18-ти томів «Білоруської енциклопедії» розміщено на одному із сайтів Білорусі ${ }^{\text {. }}$ Повноцінна національна онлайн-енциклопедія у Білорусі відсутня.

\section{Болгарія:}

- онлайн-енциклопедія «Знам»7. Створено на основі універсального однотомного болгарського видання «Българска енциклопедия А-Я» («Болгарська енциклопедія А-Я»).

\section{Греція:}

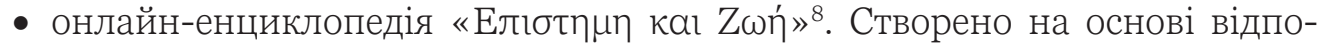
відної універсальної грецької енциклопедії ( Енциклопедія науки і житТя»).

\section{Данія:}

- онлайн-енциклопедія «Den Store Danske»9. Створено на основі універсальної данської 20-томної енциклопедії «Den Store Danske Encyklopædic» («Велика данська енциклопедія»). Від 2017 року онлайн-енциклопедія не оновлюється, проте лишається функціонувати надалі.

\section{Естонія:}

- онлайн-енциклопедія «TEA e-Entsüklopeedia» ${ }^{10}$. Створено на основі низки друкованих енциклопедичних видань Естонії.

\section{Іспанія:}

- онлайн-енциклопедія «Gran Enciclopedia de España» ${ }^{11}$. Створено на основі універсальної 22-томної енциклопедії «Gran Enciclopedia de España» («Велика іспанська енциклопедія»).

\footnotetext{
${ }^{4}$ Режим доступу: http://austria-forum.org

${ }^{5}$ Режим доступу: http://www.britannica.com

${ }^{6}$ Режим доступу: http://app.box.com/v/bielaruskaja-encyklapiedyja

7 Режим доступу: http://www.znam.bg

8 Режим доступу: http://www.gnosinet.gr

${ }_{9}^{9}$ Режим доступу: http://denstoredanske.dk

${ }^{10}$ Режим доступу: http://www.ents.ee

${ }^{11}$ Режим доступу: http://granenciclopedia.es
} 


\section{Італія:}

- онлайн-енциклопедія «Treccani» ${ }^{12}$. Створено на основі 35-томної національної енциклопедії «Enciclopediaitaliana di scienze, lettere, ed arti» («Iталійська енциклопедія наук, літератури і мистецтв»).

\section{Латвія:}

- онлайн-енциклопедія «Nacionālā enciklopēdija» ${ }^{13}$ («Національна енциклопедія»; розпочне функціонування у грудні 2018 року). Заплановано також видрукувати енциклопедію.

\section{Литва:}

- онлайн-енциклопедія «Visuotine Lietuvių Enciklopedija» ${ }^{14}$. Створено на основі відповідного 25-томного енциклопедичного видання («Універсальна литовська енциклопедія»).

\section{Македонія:}

- оцифрована енциклопедія «Македонска енциклопедија». Два оцифровані томи академічної «Македонської енциклопедії» розміщено на одному 3 македонських сайтів ${ }^{15}$. Національна онлайн-енциклопедія в Македонії відсутня.

\section{Нідерланди:}

- онлайн-енциклопедія «Grote Winkler Prins» ${ }^{16}$. Онлайн-енциклопедія $\epsilon$ продовженням відомої нідерландської енциклопедії «Winkler Prins Encyclopedie», яка почала друкуватися ще в 19 столітті.

\section{Німеччина:}

- онлайн-енциклопедія «Brockhaus» ${ }^{17}$. Створено на основі відомої універсальної «Енциклопедії Брокгауз» («Brockhaus Enzyklopädie»).

\section{Норвегія:}

- онлайн-енциклопедія «Store Norske Leksikon» ${ }^{18}$. Створено на основі відповідного 16-томного видання («Велика норвезька енциклопедія»). Особливість цієї онлайн-енциклопедії в тому, що в ній поєднано енциклопедію вільного й закритого типу. Зокрема, йдеться про те, що електронний ресурс надає опцію редагування статей для будь-якого читача; при цьому запропоновані читачами зміни затверджує (або ж відхиляє) експерт, і лише після цього стаття набуває нової редакції для перегляду.

\section{Польща:}

- онлайн-енциклопедія «Encyklopedia PWN» ${ }^{19}$. Створено на основі енци-

\footnotetext{
12 Режим доступу: http://www.treccani.it

${ }^{13}$ Режим доступу: http://enciklopedija.lv

${ }^{14}$ Режим доступу: http://www.vle.lt

${ }^{15}$ Режим доступу: http://promacedonia.com/mak_enc

${ }^{16}$ Режим доступу: http://www.winklerprins.com

${ }_{17}$ Режим доступу: http://brockhaus.de

${ }^{18}$ Режим доступу: http://snl.no

${ }^{19}$ Режим доступу: http://encyklopedia.pwn.pl
} 
клопедичних видань, опублікованих у видавництві PWN («Державне наукове видавництво»);

- онлайн-енциклопедія «Wielka Interaktywna Encyklopedia Multimedialna» 20 («Велика інтерактивна мультимедійна енциклопедія»). Створено на основі енциклопедичного видання «Popularna Encyklopedia Powszechna» («Популярна загальна енциклопедія»).

\section{Росія:}

- онлайн-енциклопедія «Большая российская энциклопедия ${ }^{21}$. Створено на основі 35-томного відповідного енциклопедичного видання («Велика російська енциклопедія»).

\section{Румунія:}

- онлайн-енциклопедія «Enciclopedia Romanieio» ${ }^{22}$. Енциклопедія вільного типу. Не витримала конкуренції з «Вікіпедією» і припинила свій розвиток (містить лише близько 5000 статей).

\section{Угорщина:}

- онлайн-енциклопедія «Magyar Nagylexikon». Нині не функціонує. Її було створено на основі відповідного 19-томного енциклопедичного видання («Велика угорська енциклопедія»);

- онлайн-енциклопедія «Magyar Virtuális Enciklopédia» («Угорська віртуальна енциклопедія $)^{23}$. Від 2005 року матеріали не оновлюють і нових не додають.

\section{Франція:}

- онлайн-енциклопедія «Encyclopaedia Universalis» ${ }^{24}$. Створено на основі відповідного 28-томного енциклопедичного видання («Універсальна енциклопедія»).

\section{Хорватія:}

- онлайн-енциклопедія «Hrvatska enciklopedija» ${ }^{25}$. Створено на основі відповідного 11-томного енциклопедичного видання («Хорватська енциклопедія»);

- онлайн-енциклопедія «Proleksis enciklopedija» ${ }^{26}$. Створено на основі відповідного 20-томного енциклопедичного видання «Opća i nacionalna enciklopedija» («Загальна і національна енциклопедія»).

\section{Чехія:}

- онлайн-енциклопедія «Encyklopedie CoJeCo» ${ }^{27}$;

- онлайн-енциклопедія «Encyklopedie Vševěd» ${ }^{28}$.

\footnotetext{
${ }^{20}$ Режим доступу: http://zapytaj.onet.pl/encyklopedia

${ }^{21}$ Режим доступу: http://bigenc.ru

${ }^{22}$ Режим доступу: http://enciclopediaromaniei.ro

${ }^{23}$ Режим доступу: http://www.hunfi.hu

${ }^{24}$ Режим доступу: http://www.encyclopaedia-universalis.fr

${ }^{25}$ Режим доступу: http://www.enciklopedija.hr

${ }^{26}$ Режим доступу: http://proleksis.lzmk.hr

${ }^{27}$ Режим доступу: http://www.cojeco.cz

${ }^{28}$ Режим доступу: http://www.vseved.cz
} 


\section{Швейцарія:}

- онлайн-енциклопедія «Historisches Lexikon der Schweiz» ${ }^{29}$. Створено на основі відповідної багатотомної краєзнавчої енциклопедії («Історичний словник Швейцарії»), особливість якої в тому, що вона має видання трьома мовами - німецькою, італійською та французькою. Відповідно онлайненциклопедія так само є тримовною.

\section{Швеція:}

- онлайн-енциклопедія «Nationalencyklopedin» ${ }^{30}$. Створено на основі 20-томного енциклопедичного видання («Національна енциклопедія»).

Насамкінець, відповідно до наших спостережень, пропонуємо деякі висновки-узагальнення.

1. Переважна більшість європейських національних онлайн-енциклопедій - це комерційні видання, до створення яких держава не має стосунку. Щоправда, видавець піклується не лише про комерційну вигоду, а й про належну високу якість матеріалу, оскільки статті в таких енциклопедіях готують фахівці. Менша частина онлайн-енциклопедій з'явилася з ініціативи і за фінансування уряду чи державних наукових або видавничих організацій.

2. Національні онлайн-енциклопедії у країнах Європи створено на основі відповідних фундаментальних друкованих енциклопедичних видань.

3. Фактично всі онлайн-енциклопедії - одномовні.

4. Всі онлайн-енциклопедії - захищені від втручання в екосистему енциклопедичних знань. Водночас окремі з них пропонують зворотний зв’язок з читачами, як, наприклад, національна онлайн-енциклопедія в Норвегіі (див. вище). У цьому контексті заслуговує на увагу й електронна «Енциклопедія Сучасної України», яка надає читачам опцію коментування (в коментарях читач має можливість запропонувати свої зміни до тексту статті, які редакція ЕСУ візьме до уваги та за доцільності зробить у статті відповідні корективи).

5. Аналіз рейтингу сайтів онлайн-енциклопедій, наведений у звіті, свідчить про те, що до них звертаються значно рідше, ніж до «Вікіпедії». На нашу думку, причиною цьому можуть бути такі чинники: 1) менша кількість статей, ніж у «Вікіпедіі» (тобто читач не впевнений, що інформацію, яка його цікавить, буде знайдено в національній онлайн-енциклопедії, а тому одразу звертається до «Вікіпедії); 2) обмежений доступ і комерціалізація (пошук інформації за умови оплати, звісно, читачеві менш привабливе, ніж на вільних засадах); 3) одномовність (по-перше, одномовність обмежує кількість читачів за мовною належністю, а багатомовність, навпаки, розширює читацьку аудиторію; по-друге, у «Вікіпедії» мовні розділи про те саме реєстрове слово часто містять інформацію, яка не збігається;

\footnotetext{
${ }^{29}$ Режим доступу: http://www.hls-dhs-dss.ch

${ }^{30}$ Режим доступу: http://www.ne.se
} 
це сприяє більшій інформативності); 4) зовнішній вигляд сайту й опції з пошуку інформації та їі «споживання» (в цьому сенсі, на нашу думку, більшість сайтів, що представляють європейські онлайн-енциклопедіі, не вирізняються високим гатунком).

\title{
ЛITEPATУРА
}

1. Андрейко Г. Экология информационного пространства: лекционный курс. Харьков, 2015. 112 с.

2. Емельяненко В., Жукова С. Википедия как источник научной информации // Информация как двигатель научного прогресса: 3б. науч. статей по итогам междунар. научно-практической конференции. Стерлитамак, 2018. С. 154-160.

3. Еремин А. Природа и физиология информационной экологии человека // Экология человека. 2000. № 2. С. 55-60.

4. Кобільник Б., Гізун А. Роль інформаційно-психологічних впливів у інформаційній війні // Актуальні задачі та досягнення у галузі кібербезпеки: Матеріали всеукраїнської науково-практичної конференції / КНТУ. Кропивницький, 2016. С. 28-29.

5. Остроухов В., Петрик В. До проблеми забезпечення інформаційної безпеки України // Політичний менеджмент. 2008. № 4. С. 135-141.

6. Рубан А. Сучасні інформаційні комунікації та їх вплив на масову політичну свідомість і здоров’я людини // Young Scientist. 2017. № 9.1 (49.1). C. 143-147.

7. Europe's online encyclopaedias. Equal access to knowledge of general interest? / N. Bentzen; European Parliamentary Research Service. Brussels, 2018.

8. Vandalism // Wikipedia. Режим доступу: http://en.wikipedia.org/wiki/Wikipedia: Vandalism.

\section{ON VIOLATION AND PROTECTION OF ECOLOGY OF ENCYCLOPEDIC KNOWLEDGE (REVIEW OF THE REPORT OF THE EUROPEAN PARLIAMENTARY RESEARCH SERVICE ON EUROPE'S NATIONAL ONLINE ENCYCLOPEDIAS)}

\author{
Oleksandr Ishchenko \\ NASU Institute of encyclopedic research, \\ Kyiv, Ukraine
}

The research is devoted to issues of the ecosystem of encyclopedic knowledge. The fact is that a reference information is now increasingly used as means of media manipulation in level of public consciousness (for political, ideological, and economic reasons). This is well traced on the example of online encyclopedias with free 
access to editing of posted information such as Wikipedia. This article is based on the description of the online analytical report on encyclopedias in Europe written by experts of the European Parliament.

Keywords: online encyclopedia, national encyclopedia, encyclopedic knowledge, information ecology, online vandalism.

\section{REFERENCES}

Andreiko, G. (2015). Ekologiia informatsionnogo prostranstva lektsionnyi kurs. Kharkov (in Russian).

Bentzen, N. (2018). Europe's online encyclopaedias. Equal access to knowledge of general interest? Brussels: European Parliamentary Research Service.

Emelianenko, V., Zhukova, S. (2018). Vikipediia kak istochnik nauchnoi informatsii. In Proceedings of the 3d International Conference "Informatsiia kak dvigatel nauchnogo progressa» (pp. 154-160). Sterlitamak (in Russian).

Kobilnyk, B., Hizun, A. (2016). Rol informatsiino-psykholohichnykh vplyviv u informatsiinii viini. In Proceedings of the Conference «Aktualni zadachi ta dosiahnennia u haluzi kiberbezpeky» (pp. 28-29). Kropyvnytskyi: KNTU (in Ukrainian).

Ostroukhov, V., Petryk V. (2008). Do problemy zabezpechennia informatsinoi bezpeky Ukrainy. Politychnyi menedzhment, 4, 135-141 (in Ukrainian).

Ruban, A. (2017). Suchasni informatsiini komunikatsii ta yikh vplyv na masovu politychnu svidomist i zdorovia liudyny. Young Scientist, 9.1(49.1), 143-147 (in Ukrainian).

Vandalism. In Wikipedia. http://en.wikipedia.org/wiki/Wikipedia:Vandalism.

Yeremin, A. (2000). Priroda i fiziologiia informatsionnoi ekologii cheloveka. Ekologiia cheloveka, 2, 55-60 (in Russian). 


\title{
ГАЛУЗЕВА ЕНЦИКЛОПЕДІЯ ЯК ВАЖЛИВИЙ ЕТАП РОЗВИТКУ НАУКОВОӦ ДИСЦИПЛІНИ ТА ЇЇ ТЕРМІНОСИСТЕМИ (НА ПРИКЛАДІ ЦИКЛУ ПРАЦЬ ІЗ ГІРНИЦТВА Й ГЕОЛОГІЇ «ГІРНИЧА ЕНЦИКЛОПЕДІЯ»)*
}

\author{
Володимир Білецький \\ НТУ «Харківський політехнічний інститут», \\ Харків, Україна \\ Геннадій Гайко \\ НТУу «Київський політехнічний інститут імені І. Сікорського», \\ Київ, Украӥна
}

\begin{abstract}
На прикладі циклу праць «Гірнича енциклопедія» показано особливості розвитку окремих наукових дисциплін - гірництва, геології; передусім їх фахового термінологічного забезпечення. Стаття характеризує «Гірничу енциклопедію», ï актуальність для технічної освіти в Україні, інтеграції загалом вітчизняної вищої освіти в європейський та світовий освітній простір.
\end{abstract}

Ключові слова: галузеві енциклопедії, Гірнича енциклопедія, технічна термінологія, технічна освіта.

Вступ. Стан термінологічної справи будь-якої держави значною мірою відображає рівень їі освіти, науки й культури. Саме тому кожна держава дбає про стан фахової мови, відображеної в освітніх і галузевих стандартах, причому стандартизація термінології неабияк сприяє утвердженню державності країни. О. Колган справедливо зазначає, що «закріплення Конституцією України статусу української мови як державної створює умови для формування

\footnotetext{
* Дослідження оприлюднено на круглому столі «Енциклопедистика в діяльності Національної академії наук України та Наукового товариства імені Шевченка», приуроченого до 100-річчя Національної академії наук України (www.roundtable2018.encyclopedia.kiev.ua).
} 
й розвитку національної термінології взагалі та їі підсистем, зокрема гірничої термінології, що є одним із найважливіших чинників національного відродження України в період її незалежності» [4, с. 1].

Вже в перші роки становлення України як незалежної держави за наказами Міністерства освіти й Держстандарту на базі НУ «Львівська політехніка» було створено Технічний комітет стандартизації науково-технічної термінології, який зробив багато корисного для розвитку й розповсюдження української фахової термінології, проте гірничий напрямок не отримав належного забезпечення. Окремі роботи провадили науковці Національного гірничого університету, Івано-Франківського університету нафти і газу, Донецького національного технічного університету, Криворізького національного університету тощо, однак ці праці не набули системного характеру й значного поширення - велика частина фахівців і студентів, особливо на сході України, продовжувала зберігати орієнтацію на російську термінологічну базу й навчальну літературу.

На одній із сесій Наукового товариства імені Шевченка (2016 року) було влучно зауважено: модернізація змісту гірничої освіти потребує сучасної термінологічної системи та оновленої інформаційної бази енциклопедичного рівня, яка охоплює широкий реєстр понять і термінів, що відображають гірництво й геологію як цілісний феномен, що розвивається. Здобутки науки й техніки постійно та своєчасно мають входити в освітній простір, забезпечуючи «кругове навчання» (дослівний переклад терміна «енциклопедія»), тобто - системний широкий погляд на пов'язані галузі діяльності. Особливо це актуально для гірництва, де «коло наук» відрізняється надзвичайно великим розмаїттям і потребує акумуляції сучасних знань і досягнень [6, с. 197].

Мета і завдання. Мета циклу праць «Гірнича енциклопедія» полягає в створенні термінологічної бази даних та енциклопедичної систематизації сучасних знань у природничих науках про Землю і прикладних гірничих дисциплінах. Це має забезпечити підвищення якості гірничої освіти та уможливить перехід освітніх процесів вищої школи (зокрема, викладання гірничо-геологічних дисциплін і створення відповідної навчальної літератури) від російської до української понятійно-термінологічної системи.

Серед завдань проекту «Гірнича енциклопедія» виокремимо такі:

1. сприяння оновленню змісту гірничої й геологічної освіти та підвищенню якості навчальної й методичної літератури шляхом створення й застосування найбільш повної й сучасної енциклопедичної інформаційної системи;

2. гуманітаризація гірничотехнічної освіти й сприяння єдності інженерних і гуманітарних знань, що забезпечується наведенням численних матеріалів з історії гірництва й геологічної науки, геологічного та гірничого законодавства, охорони праці й охорони геологічного довкілля під час експлуатації надр;

3. покращення доступу до іноземних освітніх і наукових джерел, розвиток понятійної комунікації між науковцями різних країн, уможливлення міжнародної уніфікації освітніх і наукових процесів у природничих і гірничотех- 
нічних галузях шляхом адаптації створеної термінологічної бази даних до англійських, німецьких і російських аналогів (наведення відповідників до кожного українського терміну);

4. відродження української фахової мови в галузі гірництва та геології завдяки використанню питомо українських понять і термінів, врахуванню змін в реаліях мовної практики й науки в Україні.

Стисла характеристика проекту. «Гірнича енциклопедія» - комплексна, міждисциплінарна праця, що систематизує знання в природничих науках про Землю, таких як геологія, мінералогія, петрографія, гідрогеологія, геохімія, геофізика, географія, екологія; прикладних технічних науках з видобування та первинної переробки твердих, рідинних і газоподібних корисних копалин, шахтного та підземного будівництва, маркшейдерії та геодезіі, а також відображає сучасний стан та історію гірничо-геологічної науки й освіти в країнах світу. Крім цього, праця окреслює актуальні питання геологічного та гірничого законодавства, охорони праці й охорони геологічного довкілля при експлуатації надр. «Гірнича енциклопедія не має вітчизняних аналогів і випереджає за кількістю статей подібні видання слов’янськими мовами.

Цикл праць «Гірнича енциклопедія охоплює 6 книг на 3832 сторінках формату A4 обсягом 658 друкованих аркушів, які складають два фундаментальні енциклопедичні видання - «Гірничий енциклопедичний словник» (ГЕС) [3] і «Мала гірнича енциклопедія» (МГЕ) [5]. Загальний обсяг трьох томів - 1936 сторінок (371,2 друк. аркушів).

«Гірничий енциклопедичний словник» містить 12 700, а «Мала гірнича енциклопедія» - 17350 термінологічних та номенклатурних одиниць (частину 3 них введено у мовний обіг вперше). Статті складаються зі слова-заголовка, після якого наведено відповідники російською, англійською та німецькою мовами. Статті в стислій, зручній для користування формі подають найсучаснішу наукову й науково-технічну інформацію, висвітлюють різні аспекти геологічних наук, розвідки, видобування та первинної переробки корисних копалин, знайомлять із методами наукового пошуку й інженерного проектування, популяризують світові й українські досягнення в зазначених галузях. Проект містить понад півтори тисячі ілюстрацій (рисунків, схем, фотографій), чим суттєво покращує розуміння й засвоєння матеріалу. Авторський і редакційний колектив - це понад 100 провідних науковців і практиків у галузі гірництва з понад 30 університетів, науково-дослідних інститутів, наукових спілок і організацій України, Польщі й Росії.

ГЕС і МГЕ об’єднані в спільний цикл праць «Гірнича енциклопедія», оскільки ГЕС (перші два томи) закладає основи термінологічної бази (стислі визначення, дефініціі), що була значно збільшена й розвинена в енциклопедичні статті, реалізовані у МГЕ. Крім цього, третій том ГЕС містить додаткові матеріали енциклопедичного характеру про країни, басейни, родовища, гірничі підприємства, компаніі, інститути, університети, наглядові та громадські гірничі організаціі, які не потрапили до МГЕ. Відтак обидва видання взаємопов’язані й доповнюють одне одного. 
Під час роботи автори дотримувалися інтегральних принципів термінотворення, коли проблему номінування того чи іншого поняття розв'язують індивідуально - через аналіз потенціалу словотворення в українській мові або шляхом інтерпретації вже готового терміна з іншої мови, звідки поняття запозичено і впроваджено в національну терміносистему (транскрибуванням, прямим перекладом, калькуванням). При цьому враховано й традиції вживання гірничих термінів в Україні, їхнє походження, а також ареал розповсюдження гірничих термінів-синонімів в Україні та світі.

«Гірнича енциклопедія - піонерська робота, яка передбачала підготовку й опублікування низки похідних видань (дочірніх проектів), що були у взаємодії основним проектом «Мала гірнича енциклопедія» й розвивали окремі напрямки гірничо-геологічних знань і технологій. Додатково авторський колектив підготував і опублікував 4 словники-довідники, 12 монографій, 4 підручники й 6 навчальних посібників із грифом МОН України.

Наукова новизна й практичне значення. Цикл праць «Гірнича енциклопедія» вперше створює збалансовану українськомовну термінологічну систему, охоплюючи 17350 термінологічних та номенклатурних одиниць, адаптованих до англійської, німецької й російської термінологічних баз даних, і $€$ основою для понятійної комунікації в геологічній та гірничій освіті, навчальній, методичній та науковій літературі, а також у періодичних наукових виданнях України та інших країн світу. Це забезпечує потужний ресурс сприяння розвитку природничих, технічних і гуманітарних наук й істотно впливає на покращення підготовки майбутніх спеціалістів у гірничо-геологічних галузях.

Авторами узагальнено й суттєво розвинуто фахову українську мову, зокрема геологічну, географічну, екологічну, гірничо-технологічну і гірничо-технічну термінологію. Введено низку нових термінів, причому поповнення термінологічної лексики гірників разом з освоєнням готових лексем (українських та іншомовних) здійснювалося за допомогою творення нових слів на грунті словотвірних моделей сучасної української мови. Під час роботи над циклом «Гірнича енциклопедія» напрацьовано засади творення гірничої терміносистеми, здійснено аналіз їі витоків і шляхів формування, семантичної диференціації та особливостей функціонування, що сприятиме розвиткові лінгвоукраїністики в галузі термінології, подальшому унормуванню термінології гірництва та геології. Докладніше про «Гірничу енциклопедію» в контексті термінології див. - [1].

Концепція циклу праць «Гірнича енциклопедія в враховує сучасні тенденції інтеграції галузей знань, зокрема інженерних і гуманітарних наук, що знайшло відображення у матеріалах, присвячених історії гірництва та геологічних наук, традиціям і культурній спадщині гірників, гірничому законодавству, охороні праці та навколишнього середовища тощо. Крім того, гуманітарний напрямок проекту «Гірнича енциклопедія» знайшов втілення у викладанні курсу сучасної української мови у вищих навчальних закладах (зокрема на спеціальних курсах і семінарах). Усе це є чинником гуманітаризації вітчизняної інженерної освіти й наближення ї̈ до європейських стандартів. 
До виходу «Малої гірничої енциклопедії» фахівці України користувалися російськомовною «Горной энциклопедией», що вийшла друком у 19841991 рр. Українське видання відрізняється не лише мовою, структурою чи значно більшою кількістю статей (майже вдвічі), а й відображає суттєві зміни, викликані науковими досягненнями і прогресом гірничої техніки й технологій за минулі десятиріччя. На цій підставі можна твердити, що МГЕ є найновітнішою системною базою гірничо-геологічних знань серед подібних видань слов'янськими мовами.

Цикл праць «Гірнича енциклопедія» сьогодні активно використовують у кількох освітніх процесах:

1. як навчальне видання для викладання кількох десятків дисциплін для гірничих і геологічних спеціальностей (бакалаври, спеціалісти і магістри);

2. як базисне універсальне видання для підготовки підручників, посібників, курсів лекцій, навчально-методичної літератури в гірництві та суміжних галузях і науках - геології, мінералогії, петрографії, гідрогеології, геохімії, геофізики, географії, екології, видобуванні та первинній переробці твердих, рідких і газоподібних корисних копалин, маркшейдерії та геодезії, шахтному та підземному будівництві, а також історії геологічної й гірничої науки та освіти;

3. як розгалужена система сучасних знань для підвищення професійної кваліфікації викладачів гірничих, геологічних, екологічних та географічних дисциплін вищих навчальних закладів і як довідник для студентів;

4. як ключ до англійської, німецької й російської термінологічних баз даних для покращення доступу до іноземних освітніх і наукових джерел, розвитку мобільності студентів і освітян в рамах Болонського процесу, уможливлення міжнародної уніфікації освітніх і наукових процесів у природничих і гірничотехнічних галузях.

Апробація проекту. В Україні «Мала гірнича енциклопедія» розміщена у вільному доступі на декількох інформаційних порталах, зокрема престижному «Всеукраїнська експертна мережа»를 , де вже зафіксовано декілька тисяч переглядів. Проект «Гірнича енциклопедія» неодноразово презентувався, обговорювався й отримав схвальну оцінку на багатьох міжнародних конференціях, серед них назвемо такі: XXI Всесвітній гірничий конгрес (Краків, 2008 р.); Польська «Школа експлуатації підземної» (2005-2011рр., Краків); Українська «Школа підземної розробки» (2009-2014 pр., Гаспра, Бердянськ); Форум гірників (Національний гірничий університет, Дніпропетровськ, 2013 р.); VI Міжнародна науково-технічна конференція «Енергетика. Екологія. Людина» (НТУУ «Київський політехнічний інститут імені І. Сікорського», Київ, 2013 р.); зустрічі зі студентами й викладачами в Національному гірничому університеті (Дніпро), Харківському національному університеті імені В. Каразіна, Донецькому національному технічному університеті, Донбаському державному технічному університеті (Алчевськ), Криворізькому національному університеті, Києво-Могилянській акаде-

\footnotetext{
${ }^{1}$ Режим доступу: http://www.experts.in.ua/baza/doc/download/gorE.pdf
} 
мії, Полтавському національному технічному університеті імені Ю. Кондратюка, Івано-Франківському національному технічному університеті нафти і газу тощо.

Цикл праць «Гірнича енциклопедія» висвітлено в авторитетних фахових і спеціалізованих виданнях (див. - [2]), інформацію про неї широко представлено в мережі Інтернет, зокрема у «Вікіпедії» (українська, німецька, польська, російська й грузинська версіі).

«Малу гірничу енциклопедію» підготовлено на замовлення Державного комітету телебачення і радіомовлення України за Програмою випуску соціально-значимих видань накладом 1000 примірників і доведено державним коштом до більшості міських бібліотек України та бібліотек наукових і освітніх закладів, що підкреслює високу державну оцінку цього видавничого проекту.

Висновки. Цикл праць «Гірнича енциклопедія» позитивно впливає на розвиток вітчизняної гірничої та геологічної освіти й науки та утверджує її високий авторитет у світі. Вперше створено термінологічну базу даних у геології та гірництві, що нараховує 17350 термінологічних та номенклатурних одиниць, та адаптовано її до англійської, німецької й російської термінологічних баз даних. Цикл праць «Гірнича енциклопедія» широко використовується в освітніх процесах вищої школи України; виконує свою мету й призначення, зокрема, відроджує українську фахову мову в галузі гірництва й геології, забезпечуючи перехід освітніх процесів до української понятійно-термінологічної системи; сприяє оновленню змісту гірничої й геологічної освіти та підвищенню якості навчальної й методичної літератури; робить внесок у наукове забезпечення процесу інтеграції вітчизняної вищої освіти в європейський та світовий освітній простір.

\section{ЛІТЕРАТУРА}

1. Білецький В. Загнітко А., Манець I. Досвід удосконалення сучасної української гірничої термінології // Донецький вісник НТШ. Донецьк, 2003. Т. 3. С. 97-104; Білецький В., Загнітко А., Манець І., Ященко Ю. Розвиток і функціонування у науково-технічній літературі національної гірничої та екологічної термінології // Проблеми експлуатації обладнання шахтних стаціонарних установок. Вип. 96. Донецьк, 2003. С. 222-229; Білецький В., Манець I. Проблеми української термінології в гірництві, екології та техногенній безпеці // Проблемы эксплуатации оборудования шахтных стационарных установок. Вып. 97. Донецк, 2003. С. 114-117; Білецький В., Ященко Ю., Загнітко $\Phi$., Манець I. Українська гірнича термінологія: становлення, удосконалення i вживання // Уголь Украины. 2003. № 12. С. 48-50; Білецький В. Досвід розробки національної української терміносистеми в гірничій галузі // Мова і час: збірник наукових праць. Донецьк, 2009. С. 14-20; Зуєвська Н. «Мала гірнича енциклопедія» - внесок в українську гірничу освіту, науку, термінологію // Матеріали VI Міжнародної науково-технічної конференції «Енергетика. Екологія. Людина». Вип. 5. Київ, 2014. С. 137-139.

2. Білецький В. Створення першої вітчизняної «Гірничої енциклопедії» // Вісник НУ «Львівська політехніка». Сер.: Проблеми української терміно- 
логіi. 2000. № 453. С. 483-487; Білецький В. Проект «Гірнича енциклопедія» // Новые технологии подземного строительства и добычи полезных ископаемых: Материалы международной научно-технической конференции. Алчевск: ДонДТУ. 2008. С. 207-210; Фик І. «Гірнича енциклопедія» - вагомий внесок у гірничу науку // Вісник Харківського національного університету імені В. Каразіна. 2013. № 1098. С. 149.

3. Гірничий енциклопедичний словник: У 3 т. Т. 1 / Відп. ред. В. Білецький. Донецьк: «Східний видавничий дім», 2001. 512 с.; Гірничий енциклопедичний словник: У 3 т. Т. 2 / Відп. ред. В. Білецький. Донецьк: «Східний видавничий дім», 2002. 632 с.; Гірничий енциклопедичний словник: У 3 т. Т. 3 / Відп. ред. В. Білецький. Донецьк: «Східний видавничий дім», 2004. 752 с.

4. Колган О. Семантична та словотвірна структура української гірничої термінології. Автореф. дис. на здобуття наук. ступеня канд. філол. наук, спец.: 10.01.01 - «українська мова» / Запорізький національний університет. Запоріжжя, 2009. 18 с.

5. Мала гірнича енциклопедія: У 3 т. Т. 1 / Відп. ред. В. Білецький. Донецьк: «Донбас», 2004. 640 с.; Мала гірнича енциклопедія: У 3 т. Т. 2 / Відп. ред. В. Білецький. Донецьк: «Донбас», 2007. 652 с.; Мала гірнича енциклопедія: У 3 т. Т. 3 / Відп. ред. В. Білецький. Донецьк: «Східний видавничий дім», 2013. $644 \mathrm{c}$.

6. Соболь В. Львів, 26.03.2016: XXVII наукова сесія наукового товариства ім. Шевченка в Україні // Studia Polsko-Ukrainskie. 2016. Т. 3. С. 193-200.

\title{
SUBJECT SPECIFIC ENCYCLOPEDIAS AS AN IMPORTANT STAGE IN THE DEVELOPMENT OF SCIENTIFIC DISCIPLINES AND TERIMINOLOGY SYSTEMS (ON EXAMPLE OF THE MINING ENCYCLOPEDIA AS A WORK IN MINING INDUSTRY AND GEOLOGY)
}

\author{
Volodymyr Biletskyi \\ Kharkiv Polytechnic Institute, \\ Kharkiv, Ukraine
}

Hennadii Haiko

Igor Sikorsky Kyiv Polytechnic Institute, Kyiv, Ukraine

The peculiarities of the development of some scientific disciplines (such as mining, geology), primarily the professional terminology system are shown on the example of the project The Mining Encyclopedia (ukr .: Hirnycha Entsyklopediia). The study describes The Mining Encyclopedia, its relevance for technical education 
in Ukraine, as well as for the integration of national higher education in the European and world educational space in general.

Keywords: subject specific encyclopedias, The Mining Encyclopedia, technical terminology, technical education.

\section{REFERENCES}

Biletskyi, V. (Red.). (2001). Hirnychyi entsyklopedychnyi slounyk (Vol. 1). Donetsk: Skhidnyi vydavnychyi dim (in Ukrainian); Biletskyi, V. (Red.). (2002). Hirnychyi entsyklopedychnyi slounyk (Vol. 2). Donetsk: Skhidnyi vydavnychyi dim (in Ukrainian); Biletskyi, V. (Red.). (2004). Hirnychyi entsyklopedychnyi slounyk (Vol. 3). Donetsk: Skhidnyi vydavnychyi dim (in Ukrainian).

Biletskyi, V. (Red.). (2004). Mala hirnycha entsyklopediia (Vol. 1). Donetsk: Donbas (in Ukrainian); Biletskyi, V. (Red.). (2007). Mala hirnycha entsyklopediia (Vol. 2). Donetsk: Donbas (in Ukrainian); Biletskyi, V. (Red.). (2013). Mala hirnycha entsyklopediia (Vol. 3). Donetsk: Donbas (in Ukrainian).

Biletskyi, V. (2008). Proekt «Hirnycha entsyklopediia». In Proceedings of the International Conference «Novye tekhnologii podzemnogo stroitelstua $i$ dobychi poleznykh iskopaemykh» (pp. 207-210). Alchevsk (in Ukrainian); Biletskyi, V. (2000). Stvorennia pershoi vitchyznianoi «Hirnychoi entsyklopedii». Visnyk NU «Lvivska politekhnika». Problemy ukrainskoi terminolohii, 453, 483-487 (in Ukrainian); Fyk, I. (2013). «Hirnycha entsyklopediia» - vahomyi vnesok u hirnychu nauku. Visnyk Kharkivskoho natsionalnoho universytetu imeni V. Karazina, 1098, 149 (in Ukrainian).

Biletskyi, V., Zahnitko, A., Manets, I. (2003). Dosvid udoskonalennia suchasnoi ukrainskoi hirnychoi terminolohii. Donetskyi visnyk Naukovoho tovarystva imeni Shevchenka, 3, $97-104$ (in Ukrainian); Biletskyi, V., Zahnitko, A., Manets, I., Yashchenko, Yu. (2003). Rozvytok i funktsionuvannia u naukovo-tekhnichnii literaturi natsionalnoi hirnychoi ta ekolohichnoi terminolohii. Problemy ekspluatatsii obladnannia shakhtnykh statsionarnykh ustanovok, 96, 222-229 (in Ukrainian); Biletskyi, V., Manets, I. (2003). Problemy ukrainskoi terminolohii v hirnytstvi, ekolohii ta tekhnohennii bezpetsi. Problemy ekspluatatsii obladnannia shakhtnykh statsionarnykh ustanovok, 97, 114-117 (in Ukrainian); Biletskyi, V., Yashchenko, Yu., Zahnitko, F., Manets, I. (2003). Ukrainska hirnycha terminolohiia: stanovlennia, udoskonalennia i vzhyvannia. Ugol Ukrainy, 2, 48-50 (in Ukrainian); Biletskyi, V. (2009). Dosvid rozrobky natsionalnoi ukrainskoi terminosystemy v hirnychii haluzi. In Mova i chas (pp. 14-20). Donetsk (in Ukrainian); Zuievska, N. (2014). «Mala hirnycha entsyklopediia» - vnesok v ukrainsku hirnychu osvitu, nauku, terminolohiiu. In Proceedings of the 6th International Conference «Enerhetyka. Ekolohiia. Liudyna» (pp. 137-139). Kyiv (in Ukrainian).

Kolhan, O. (2009). Semantychna ta slovotvirna struktura ukrainskoi hirnychoi terminolohii. (Thesis abstract). Zaporizhzhia National University, Zaporizhzhia (in Ukrainian).

Sobol, V. (2016). Lviv, 26.03.2016: 27th naukova sesiia naukovoho tovarystva im. Shevchenka v Ukraini. Studia Polsko-Ukrainskie, 3, 193-200 (in Ukrainian). 


\title{
АКАДЕМІЧНІ ОНЛАЙН-ЕНЦИКЛОПЕДЇ̈ В КОНТЕКСТІ РОЗВИТКУ СУЧАСНОГО ІНФОРМАЦІЙНОГО ПРОСТОРУ
}

\author{
Микола Железняк, Олександр Іщенко \\ Інститут енциклопедичних досліджень НАН Украӥни, \\ Київ, Украӥна
}

\begin{abstract}
У статті схарактеризовано явище електронної енциклопедистики й досліджено електронні енциклопедії, створені установами Національної академії наук України, що функціонують в інтернет-середовищі. Виявлено, що електронні енциклопедії можна поділити на кілька різновидів, основний із яких - онлайн-енциклопедії, що найбільшою мірою вирізняються на тлі класичних друкованих видань характеристиками, спричиненими розвитком інформаційних технологій. Відповідно до цього поділу окреслено вітчизняні академічні енциклопедичні ресурси. Висунуто ідею щодо актуальності створення онлайн-енциклопедії про Національну академію наук України, а також констатовано, що наявні онлайненциклопедії не забезпечені повною мірою великим спектром технологічних можливостей їх використання.
\end{abstract}

Ключові слова: онлайн-енциклопедистика, електронні енциклопедії, Національна академія наук України, інформаційний простір, інтернет-технології, «Енциклопедія Сучасної України», «Вікіпедія .

Найприкметніша особливість світової енциклопедистики початку XXI століття - розвиток електронних енциклопедій, зумовлений прогресом інформаційних технологій. А. Альшева справедливо зазначає, що онлайненциклопедії є породженням епохи інформаційного суспільства [1, с. 43]. Нині часто зауважують, що електронна енциклопедистика певною мірою витісняє класичну з їі традицією укладання багатотомних книжкових видань та лаконічним стилем представлення матеріалів (скорочення слів, дрібний шрифт, обмежений в кількості і розмірі іконографічний матеріал тощо), позаяк низка відомих у світі видавництв відмовилася від друкованих видань й оприлюднює 
їх лише в електронному форматі. До того ж з'явилося багато нових енциклопедичних проектів, що існують винятково в інформаційному просторі, тобто лише в мережі Інтернет. Таку тенденцію спричинено прикметними рисами електронної енциклопедистики, що на тлі класичної енциклопедичної справи виглядають перевагами. Серед них, наприклад, - зручність у створенні енциклопедій (видавці оптимізують свою роботу й економлять кошти на друкові видань) та їх використанні (читачі використовують всі технічні можливості для пошуку, ознайомлення й засвоєння інформації, які забезпечує сучасний стан розвитку інтернет-технологій). Докладніше про електронні енциклопедії див.: [4]. Із появою й розвитком електронної енциклопедистики загальний інтерес до енциклопедично-довідкової інформації у суспільстві не зменшився, а, вірогідно, і збільшився. Підтвердженням цьому може бути той факт, що сайт найпопулярнішої у світі онлайн-енциклопедії «Вікіпедія» в багатьох країнах світу входить до рейтингової десятки найбільш відвідуваних, що засвідчує неабияку зацікавленість суспільства в енциклопедичних знаннях.

Згідно зі Статутом Національної академії наук України, серед завдань іï діяльності є здійснення пропаганди досягнень науки і техніки, сприяння поширенню наукових знань, систематичне висвітлення результатів досліджень у засобах масової інформації та інших джерелах ${ }^{1}$ Уважаємо, що наукові результати кожної установи Національної академії наук України презентувати суспільству доречно у вигляді енциклопедичних видань, адже, як зазначають В. Смолій, Г. Боряк, «енциклопедичні студії посідають особливе місце в європейській та світовій науці, оскільки не лише узагальнюють і систематизують наші знання, а й представляють їх суспільству» [5, с. 44]. Саме енциклопедичний формат систематизації знань істотно сприяє їхньому поширенню й споживанню серед широких верств населення. Водночас, як стверджує Н. Гаврилишина, видання електронних енциклопедій становить посилений інтерес, а також свідчить про престиж та освіченість країни. Загальнодоступна онлайненциклопедія «Вікіпедія» показала суспільству чого саме не вистачає сучасній українській науці, зокрема популяризації маловідомих подій та фактів і спрощеного доступу до інформації [2].

Онлайн-енциклопедії з погляду доступності, ймовірно, мають переваги перед книжковими виданнями, так як нині Інтернет є найбільшим джерелом інформації, яким користується більшість людей. Для ознайомлення з онлайненциклопедією необхідно лише скористатися пошуком в Інтернеті, а ознайомлення з книжковою енциклопедією вимагає її попереднє придбання, що потребує часу й коштів. Більше того, саме з точки зору представлення наукової інформації, що актуально для установ Національної академії наук України, електронним виданням властиві й інші переваги на зразок можливості застосування новітніх інформаційно-комунікативних технологій для зручного подання наукової інформації (тексту, таблиць, графіків, анімації тощо).

${ }^{1}$ Статут Національної академії наук України, зареєстрований Міністерством юстиції України 27.07.2016 р. С. 7. 
В теоретико-термінологічному плані електронну енциклопедистику протиставляють класичній. У свою чергу, термін «електронна енциклопедистика» дещо застарілий, і сьогодні більш точно говорити про онлайн-енциклопедистику (або веб-енциклопедистику, чи інтернет-енциклопедистику), яка спочатку була «еволюційною гілкою в електронній енциклопедистиці, а нині спостерігаємо тенденцію до термінологічного заступлення цього поняття. За визначенням фахівців, електронна енциклопедія - це джерело інформації в електронній формі, яке охоплює найповніший та достовірний довідковий об’єктивний, науково-вивірений матеріал з однієї або декількох галузей знань у вигляді статей, аудіо- та відеоматеріалів для задоволення інформаційних потреб людини з доступом через локальну (CD, DVD диски) та глобальну (Інтернет) мережі [3, с. 400]. Однак нині локальні носіі інформації (CD, DVD диски) фактично не використовуються - ї замінив Інтернет.

В українському інформаційному просторі нині можна виділити два типи електронних енциклопедій (це стосується як академічних онлайненциклопедій, так і будь-яких інших):

- цифрові версії друкованих енциклопедій;

- власне онлайн-енциклопедіі.

У свою чергу, серед оцифрованих енциклопедій виокремлюємо кілька різновидів залежно від форми представлення в мережі Інтернет:

- ті, що представлені у вигляді електронних книг;

- ті, що представлені у вигляді сайту.

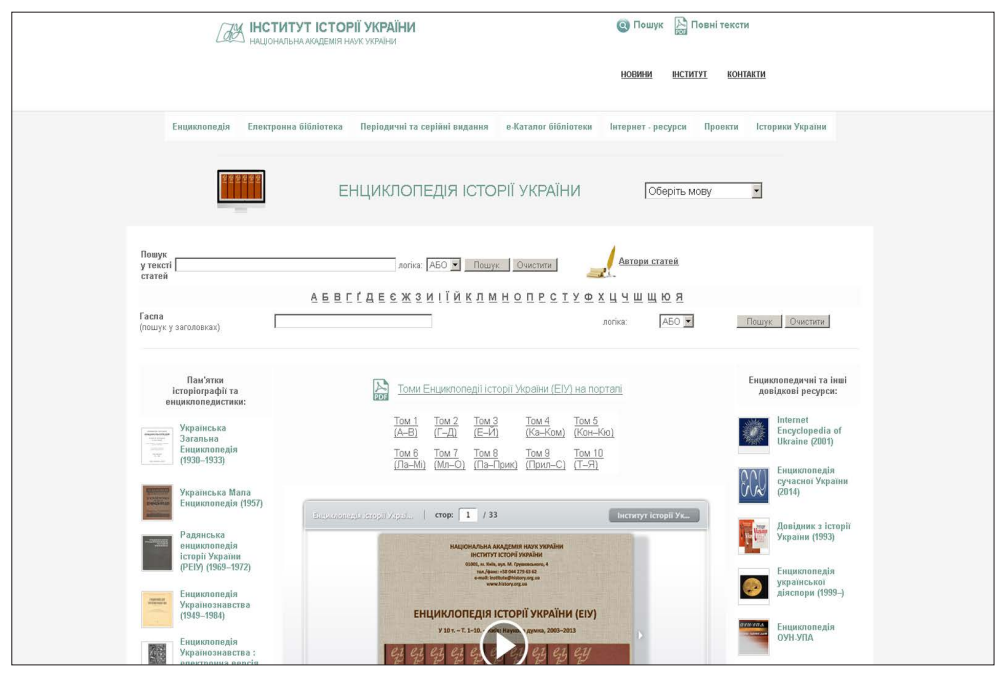

Рис. 1. Зображення веб-інтерфейсу «Енциклопедії історії України»

Цифрові електронні енциклопедії, представлені для читача у традиційному для електронних книг PDF-форматі (рідше DjVu-форматі), становлять собою копію паперових аналогів, зберігаючи відповідну сторінкову структу- 
ру, розмітку тощо. Сюди можна віднести всі паперові енциклопедіі, створені в Національній академї наук України, адже ті, що не мають цифрових копій, рано чи пізно будуть оцифровані й розміщені в мережі Інтернет як PDFфайли (або DjVu-файли) - на сайті відповідної установи або в електронних бібліотеках, репозитаріях, архівах тощо). Чимало академічних енциклопедій вже мають цифрові копї (створені одночасно з друкованими або оцифровані з друкованих оригінальних видань), серед них, зокрема, «Енциклопедія історії України» (розміщено на сайті Інституту історії України НАН України PDF-файлами), «Українська мова: енциклопедія» (розміщено DjVu-файлом на різних сайтах), «Мала гірнича енциклопедія» (розміщено PDF-файлами на різних сайтах) тощо. Та чи можна називати онлайн-енциклопедіями такі видання? Гадаємо, ні, адже вони - друковані енциклопедіі, а наявність у них електронних копій не робить їх онлайн-енциклопедіями. Інакше кажучи, їм не властиве те, що передбачають такі поняття, як «онлайн», «інтернет», «вебтехнологїі тощо.

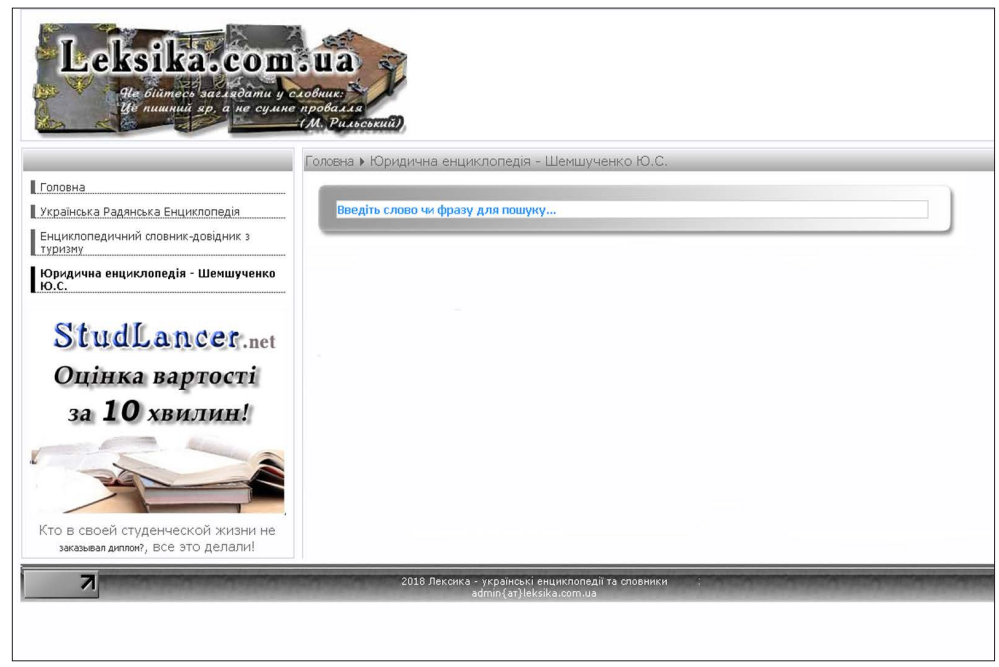

Рис. 2. Зображення веб-інтерфейсу «Юридичної енциклопедії»

Цифрові енциклопедії, представлені для читача у веб-форматі, позбавлені прив'язки до друкованого оригіналу з його посторінковою розміткою тексту, до того ж у них забезпечено можливість шукати довідковий матеріал завдяки тій чи іншій навігації сайту. Серед таких енциклопедій назвемо згадану вище «Енциклопедію історії України» (рис. 1), адже на веб-сторінці Iнституту історії України НАН України можна знайти не лише цифрову копію всіх томів, а й електронну версію енциклопедії у веб-форматі ${ }^{2}$ - на головній сторінці енциклопедії $є$ можливість здійснювати пошук за гаслами, кожне

${ }^{2}$ Режим доступу: http://resource.history.org.ua/cgi-bin/eiu/history.exe?C21COM=F $\underline{\& I 21 D B N=E I U \& P 21 D B N=E I U}$ 
гасло має окрему сторінку, у статтях перехресні посилання функціонують як гіперпосилання. Інший приклад - «Юридична енциклопедія (рис. 2) Інституту держави і права імені Володимира Корецького НАН України (ї розміщено на сайті «Лексика» в окремому розділі ${ }^{3}$ поруч з іншими довідковими виданнями, де вона має структуру, безвідносну до друкованих томів).

Особливість таких енциклопедій полягає в тому, що, незважаючи на відмінність форми, за змістом вони лишаються копією паперових видань.

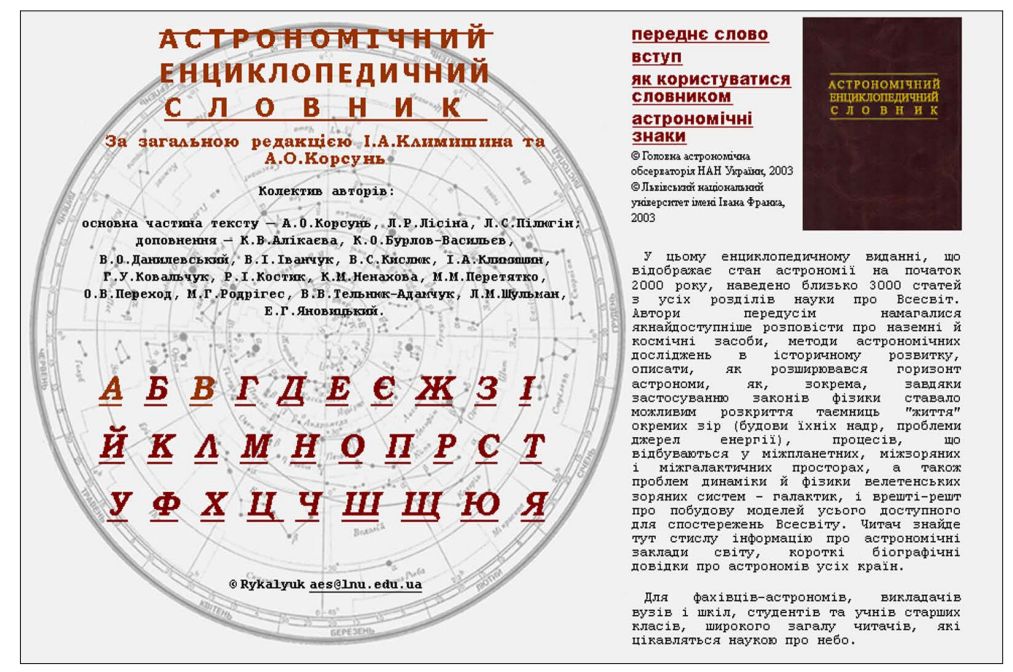

Рис. 3. Зображення веб-інтерфейсу «Астрономічного енциклопедичного словника»

Подібні видання коректно йменувати онлайн-енциклопедіями передусім формально, оскільки з погляду технічного оформлення вони набувають ознак, що відсутні в друкованому оригіналі та найголовніше - функціонують лише при підключенні до Інтернету, мають власну веб-адресу в межах того чи іншого сайту (але не мають власного сайту), тож не можуть «мігрувати» в Інтернеті по різних сайтах, як PDF-файли.

«Астрономічний енциклопедичний словник» ${ }^{4}$ (рис. 3), підготовлений науковцями Головної астрономічної обсерваторії НАН України та Львівського національного університету імені Івана Франка, поєднує в собі два описані вище різновиди цифрових видань, оскільки цей онлайн-ресурс має власну головну сторінку на сайті згаданого Львівського університету, на якій пропонується навігація матеріалу за літерами, однак кожну літеру представляє окремий PDF-файл.

Другий тип електронних енциклопедичних видань - власне онлайненциклопедії як окремі енциклопедичні ресурси, що вирізняються власним

\footnotetext{
${ }^{3}$ Режим доступу: http://leksika.com.ua/legal

${ }^{4}$ Режим доступу: http://astro.lnu.edu.ua/astro
} 
сайтом, створеним спеціально для енциклопедії (технічні можливості сайту забезпечують швидкість віднайдення енциклопедії в мережі, зручність пошуку інформації в ній, їі читання, засвоєння, опрацювання тощо). Інтернетресурси такого типу є онлайн-енциклопедіями і за формою, і за змістом. Деякі зарубіжні енциклопедисти на основі аналізу трьох поважних універсальних видань - «Britannica» ${ }^{5}$, «Brockhaus» ${ }^{6} \mathrm{i}$ «NE» ${ }^{7}-$ виокремили 15 релевантних характеристик, що визначають власне онлайн-енциклопедії (табл. 1).

Табл. 1. Визначальні особливості

онлайн-енциклопедій [6, с. 22]

\begin{tabular}{|l|c|c|c|}
\hline Характеристики & Britannica & NE & Brockhaus \\
\hline Доступ із різних гаджетів & + & + & + \\
\hline Регулярне оновлення застарілих даних & + & + & + \\
\hline Об`єктивність інформаціі (перевірена експертом) & + & + & + \\
\hline $\begin{array}{l}\text { Багатовимірність контенту (медіаресурсний } \\
\text { супровід) }\end{array}$ & + & + & + \\
\hline Багаторівневість контенту & + & + & + \\
\hline Інтегрованість із системою освіти & + & + & + \\
\hline Багатофункціональність веб-сайту енциклопедіі & + & + & + \\
\hline Інтеграція з соціальними мережами & + & + & + \\
\hline Інтерактивність & + & + & + \\
\hline Багатомовність & + & + & - \\
\hline Опрацювання інформаціі (копіювання, зберігання) & + & + & + \\
\hline Наявність підписки & + & + & + \\
\hline Особистий кабінет & + & + & + \\
\hline Моніторинг користувацьких запитів & + & + & + \\
\hline
\end{tabular}

Отже, онлайн-енциклопедії - це цілком відмінне явище від класичних енциклопедичних видань у зв'язку з наявністю в них низки функціональних компонентів, властивих лише інтернет-ресурсам. Одразу зауважимо, що, на жаль, жодна з українських електронних енциклопедій не може похвалитися наявністю всіх із можливих характеристик, які наведено в таблиці. Загалом академічних онлайн-ецниклопедій поки що обмаль.

У свою чергу, онлайн-енциклопедіі можна поділити на:

- ті, що мають паперові аналоги;

- ті, що не мають паперових аналогів.

Перший різновид онлайн-енциклопедій забезпечує передусім популяризацію й поширення в інформаційному просторі знань, опублікованих у

\footnotetext{
${ }^{5}$ Режим доступу: http://eb.com

${ }^{6}$ Режим доступу: https://brockhaus.de

${ }^{7}$ Режим доступу: http://ne.se
} 
друкованих виданнях. Основний масив контенту в таких онлайн-енциклопедіях є адаптацією текстів із друкованих томів. Проте текстовий контент може бути доповнено звуковим, фото- чи відеорядом, що, ясна річ, відсутній у паперових оригіналах. Чільне місце серед них займає «Енциклопедія Сучасної України» Інституту енциклопедичних досліджень НАН України (рис. 4), яку створюють на основі відповідного багатотомного видання. Сайт енциклопедіï має власний мультимедійний ресурс, що вирізняється, окрім енциклопедичних статей (кожна з яких має власну сторінку), наявністю фотогалерей, актуальною щоденною інформацією-календарем про відомих осіб, стрічкою енциклопедичних новин, інтеграцією із соціальними мережами та обговоренням статей (впроваджено можливість лишати коментарі до статей).

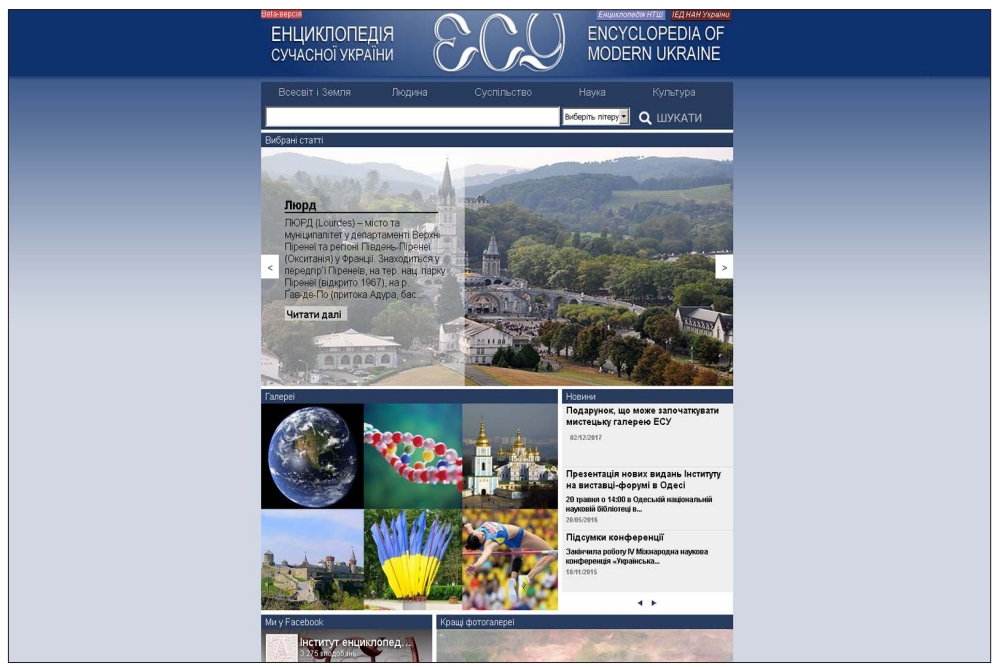

Рис. 4. Зображення веб-інтерфейсу

«Енциклопедії Сучасної України»

Ще один приклад - онлайнова «Шевченківська енциклопедія ${ }^{9}$, в основі якої 6-томне універсальне довідкове видання з такою ж назвою про життєвий і творчий шлях видатного українського поета, яке підготував Інститут літератури імені Тараса Шевченка НАН України за участю шевченкознавців України та діаспори (рис. 5). Онлайн-енциклопедія становить собою портал із багатьма тематичними розділами про видатного українця, а також мультимедійні блоки (музеї та 3-d тури, пам'ятники, місця перебування, аудіокниги, телепередачі тощо - тобто все те, що не можливо реалізувати в рамках книжкових видань).

\footnotetext{
${ }^{8}$ Режим доступу: http://esu.com.ua

${ }^{9}$ Режим доступу: http://kobzar.ua
} 


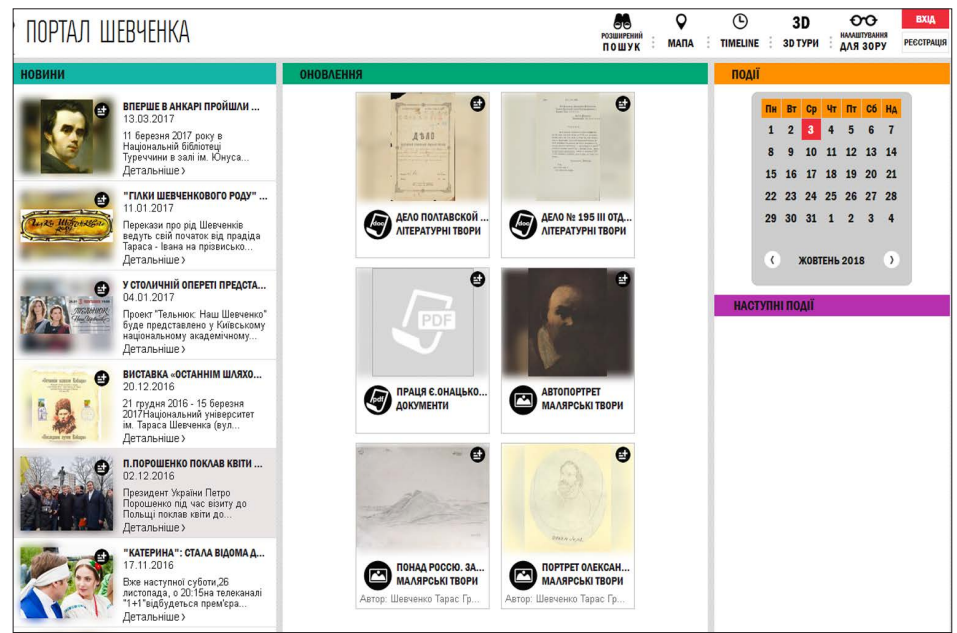

Рис. 5. Зображення веб-інтерфейсу «Шевченківської енциклопедії»

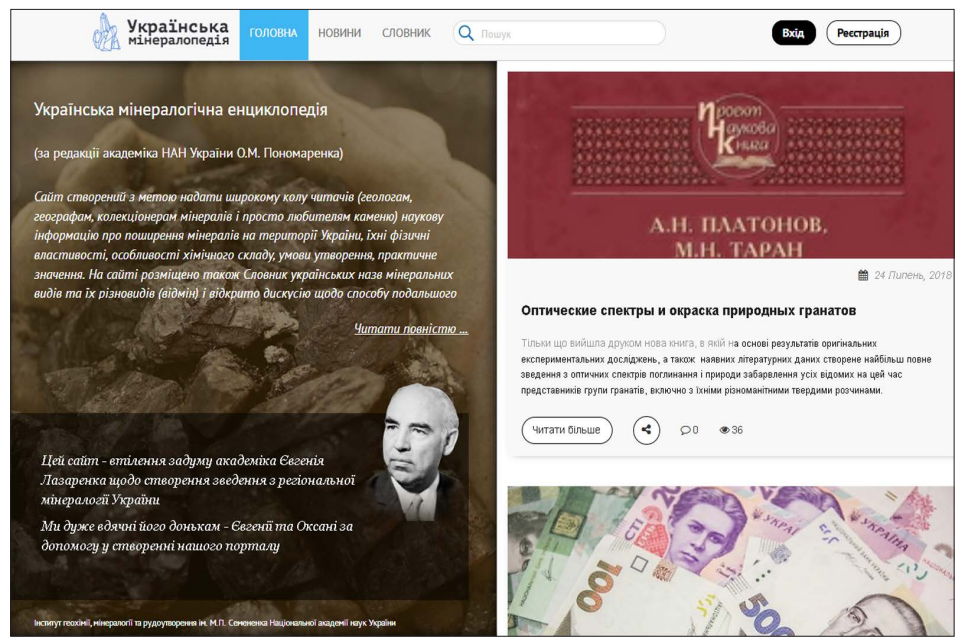

Рис. 6. Зображення веб-інтерфейсу «Української мінералопедії»

Другий різновид власне онлайн-енциклопедій - ті, що не мають друкованих аналогів. Для прикладу назвемо «Українську мінералопедію» - мінералогічну онлайн-енциклопедію України ${ }^{10}$ Інституту геохімії, мінералогіі та рудоутворення імені Миколи Семененка НАН України (рис. 6). Щоправда, варто зауважити, що основний масив інформації складають матеріали з циклу друкованих праць, об’єднаних назвою «Гірнича енциклопедія». Та все ж окремої паперової «Української мінералопедії не існує.

\footnotetext{
${ }^{10}$ Режим доступу: http://mineralopediaukraine.com
} 
До цього різновиду онлайн-енциклопедій можна віднести «Електронний архів Михайла Грушевського» ${ }^{11}$ Національної бібліотеки України імені Володимира Вернадського НАН України (рис. 7). Автори не називають цей проект енциклопедією, оскільки він не складається з енциклопедичних статей, а є фундаментальною інформаційною базою про видатного українського діяча, де акумульовано його твори, біографічні документи, листування, праці про нього, іконографічні матеріали (фотодокументи, ілюстрації з видань), відеоматеріали (документальні та документально-постановочні фільми) тощо. Однак для поширення знань у суспільстві цей інтернет-ресурс має таке ж значення, яке б мала персональна енциклопедія про М. Грушевського. Прикметно, що інформаційний ресурс багатомовний (понад 40 мов світу), отже, є доступний для мільйонів зацікавлених людей зі всього світу.

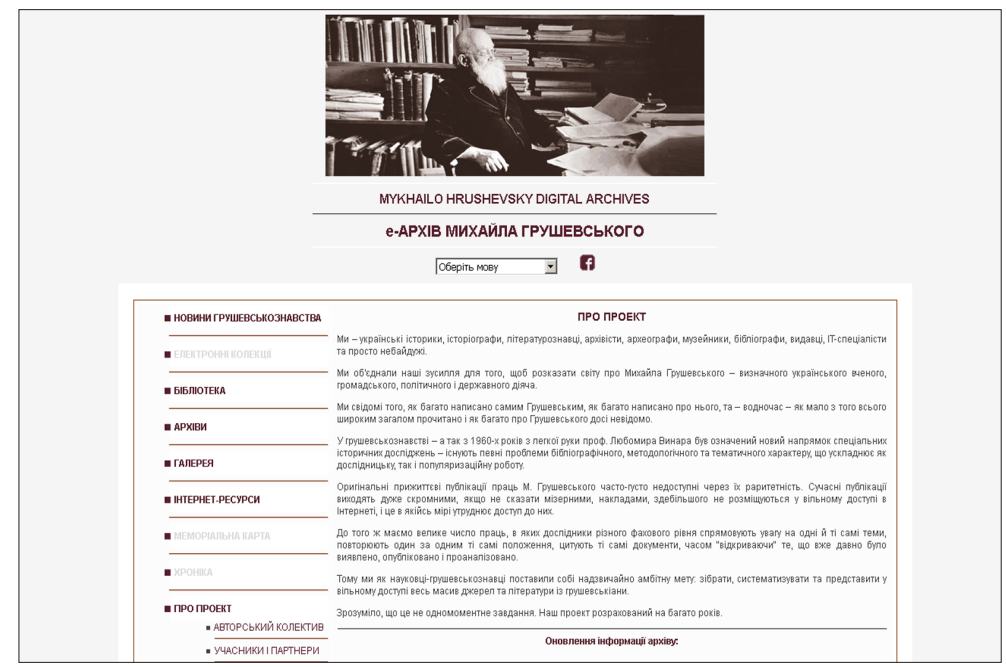

Рис. 7. Зображення веб-інтерфейсу «е-Архіву Михайла Грушевського»

В Україні серед онлайн-енциклопедій вирізняються такі, що презентують навчальні заклади (типологічно такі енциклопедії, на думку дослідників, належать до регіональних). Йдеться, наприклад, про «Енциклопедію Київського національного університету імені Тараса Шевченка» ${ }^{12}$, що всебічно охоплює та інформаційно представляє за персоналійним і тематичним принципами історію університету від часу заснування до сьогодні. Прикметно, що ця енциклопедія планувалася від початку як двотомне друковане видання, втім реалізувалася як онлайн-енциклопедія. Подібні енциклопедіі (електронні або друковані) мають й інші заклади вищої освіти України (Львівський національний університет імені Івана Франка, Національний університет «Острозька академія»). Уважаємо цілком доречним і необхідним створення онлайн-

\footnotetext{
${ }^{11}$ Режим доступу: http://hrushevsky.nbuv.gov.ua

${ }^{12}$ Режим доступу: http://eu.univ.kiev.ua
} 
енциклопедії про Національну академію наук України - іiі історію, структуру, видатних науковців, наукові досягнення світового й національного рівнів тощо, позаяк 100-річна діяльність Академії уповноважує на їі експлікацію в енциклопедичному форматі. Між іншим, варто згадати й про Наукове товариство імені Шевченка, яке разом з Інститутом енциклопедичних досліджень НАН України започаткувало в 2012 році відповідну енциклопедію - «Наукове товариство імені Шевченка» (щоправда, їі оприлюднюють як паперове багатотомне видання).

Загалом же, зважаючи на нинішній високий рівень розвитку інформаційних технологій, академічних онлайн-енциклопедій, підготовлених установами Національної академії наук України, поки що мало, а ті, що є, не використовують повний спектр технічних і змістових можливостей при їх створенні. Це актуалізує проблеми української електронної енциклопедистики та необхідність подальших досліджень і технічних розробок у цьому напрямі.

\section{ЛІТЕРАТУРА}

1. Альшева А. Переклад німецької Вікіпедії як шлях до розширення Uanet // Мовні і концептуальні картини світу. 2013. Вип. 46 (1). С. 42-48.

2. Гаврилишина Н. Регіональна енциклопедистика Полтавщини // Уманська старовина. 2016. № 1.

3. Жежнич П., Гірняк М. Особливості формування енциклопедії в сучасних умовах розвитку інформаційних технологій // Вісник Національного університету «Львівська політехніка». 2012. № 732: Комп’ютерні науки та інформаційні технології. С. 400-405.

4. Железняк М. Українська електронна енциклопедистика: тенденції розвитку та місце в інформаційному просторі держави // Енциклопедичний вісник України. 2017. Ч. 8-9. С. 7-21.

5. Смолій В., Боряк Г. Сучасна історична енциклопедистика: здобутки і перспективи розвитку // Вісник НАН України. 2015. № 3. С. 44-60.

6. Ялафов Ф., Гилязов И., Хабибуллин М. Методологические основы онлайнэнциклопедии // Международный журнал прикладных и фундаментальных исследований. 2017. № 10. С. 20-24. 


\title{
ACADEMIC ONLINE ENCYCLOPEDIAS IN WIEV OF THE RECENT INFORMATION SPACE DEVELOPING
}

\author{
Mykola Zhelezniak, Oleksandr Ishchenko \\ Institute of encyclopedic research, \\ Kyiv, Ukraine
}

The article describes the phenomenon of the electronic encyclopedia activity and investigates the electronic Internet encyclopedias created by the institutions of the National Academy of Sciences of Ukraine. It has been discovered that electronic encyclopedias can be divided into several varieties, the main of which is online encyclopedias, which are highly distinguished in comparison with classical printed publications by the characteristics caused by the development of information technology. In accordance with this division, the national academic encyclopedic resources are characterized in the article. The idea of the importance of creating an online encyclopedia about the National Academy of Sciences of Ukraine is presented; it also argued that current online encyclopedias are not fully equipped with a wide range of technological opportunities for their use.

Keywords: online encyclopedia activity, electronic encyclopedias, National Academy of Sciences of Ukraine, information space, Internet technologies, Encyclopedia of modern Ukraine, Wikipedia.

\section{REFERENCES}

Alsheva, A. (2013). Pereklad nimetskoi Vikipedii yak shliakh do rozshyrennia Uanet. Movni i kontseptualni kartyny svitu, 46(1), $42-48$ (in Ukrainian).

Havrylyshyna, N. (2016). Rehionalna entsyklopedystyka Poltavshchyny. Umanska starovyna, 1 (in Ukrainian).

Smolii, V., Boriak, H. (2015). Suchasna istorychna entsyklopedystyka: zdobutky i perspektyvy rozvytku. Visnyk NAN Ukrainy, 3, 44-60 (in Ukrainian).

Yalafov, F., Giliazov, I., Khabibullin, M. (2017). Metodologicheskie osnovy onlainentciklopedii. Mezhdunarodnyi zhurnal prikladnykh i fundamentalnykh issledovanii, 10, 20-24 (in Russian).

Zhelezniak, M. (2017). Ukrainska elektronna entsyklopedystyka: tendentsii rozvytku ta mistse v informatsiinomu prostori derzhavy. Entsyklopedychnyi visnyk Ukrainy, 8-9, 7-21 (in Ukrainian).

Zhezhnych, P., Hirniak, M. (2012). Osoblyvosti formuvannia entsyklopedii v suchasnykh umovakh rozvytku informatsinykh tekhnolohii. Visnyk Natsionalnoho universytetu «Lvivska politekhnika», 732 (Kompiuterni nauky ta informatsiini tekhnolohii), 400-405 (in Ukrainian). 


\title{
МАТЕРІАЛИ \\ ДО СЛОВНИКА ЕНЦИКЛОПЕДИЧНИХ ТЕРМІНІВ
}

\author{
MATERIALS \\ TO GLOSSARY FOR ENCYCLOPEDIA SCIENCE
}

Над укладанням словникових статей працювали:

Тетяна Березюк, Олександр Іщенко,

Микола Железняк (відп. ред.), Світлана Очеретянко,

Руслан Пилипчук, Олег Савченко, Наталя Фещенко, Анатолій Шушківський 


\begin{abstract}
ÁBTOP
(англ. autor) - особа, яка створила будь-яку наукову працю, літературний чи мистецький твір тощо. В енциклопедичній справі А. - той, хто написав енциклопедичну статтю чи енциклопедію. Може бути однією особою або колективом (див.: Авторський колектив). Авторство (ініціали і прізвище або повне імя і прізвище) зазначають зазвичай під статею. Не існує стандарту регламентації порядку подання автора (ініціали та прізвище або повне ім'я та прізвище). В окремих енциклопедичних статтях автора не зазначають (див.: Стаття редакційна).
\end{abstract}

\section{А́ВТОРСЬКИЙ КОЛЕКТИ́В}

(англ. composite authors) - група осіб, які об’єдналися з метою спільного написання енциклопедичної статті чи енциклопедії за узгодженим задумом (див.: Енциклопедї концепція) і планом.

\section{АКТУАЛІЗА́ЦІЯ ІНФОРМА́ЦIї}

(англ. content updating) - сукупність дій, спрямованих на оновлення в енциклопедичній cmammi застарілих даних із метою надання їм відповідності нині актуальній (достовірній) інформаціі. Актуалізуватися можуть не лише статті, а й сло́вник енциколопедї. У статтях інформацію актуалізують за допомогою редукціі чи заміни застарілих даних новими або лише доповненням (розширенням за рахунок нових важливих відомостей). Нині А. і. найхарактерніша для онлайн-енциклопедій (див. також: Енциклопедія електронна), оскільки в них це легко реалізувати. В енциклопедіях, які виходять друком, А. і. забезпечують публікуванням окремих додаткових томів. Для багатотомних видань такими публікаціями традиційно $є$ щорічники (див.: Том додатковий). У них додають не лише актуалізовані статті, а й цілком нові (за актуалізованим реєстром гасел), що позначають нові актуалізовані поняття, терміни, явища. Незалежно від форми представлення довідкової інформації А. і. в енциклопедіях має здійснюватися регулярно з визначеною періодичністю.

\section{АНКЕТУВА́ННЯ}

(англ. questionnaire) - один із методів збирання достовірної інформації для створення енциклопедичних стамей. Належить до вторинних методів збирання інформації для енциклопедичних вцданъ. А. використовують переважно для написання статей редакційних, рідше - для підготовки статей авторських. В енциклопедичній справі методика А. принципово не відрізняється від застосування в інших наукових галузях.

\section{АНОТА́ЩІя}

(англ. annotation note) - структурна одиниця сло́вника енциклопедичного видання, що є стислим тлумаченням реєстрового слова (див. також: Гасло). Може містити до того ж коротку інформацію про читацьке призначення, основні питання, необхідні для висвітлення, обсяг майбутньої сmammi тощо. 


\section{АПАРА́Т ВИДА́ННЯ}

(англ. equipment of edition) - додаткові (довідкові, наукові чи пояснювальні) до основного тексту енциклопедичного видання допоміжні матеріали, що призначені для покращення умов користування ним. Структура А. в. залежить від типу енциклопедї.

\section{БА́ЗА ДА́НИХ}

(англ. database) - сукупність упорядкованої інформації в електронному та паперовому вигляді (див. також: Оригінал), що використовується для створення статей в енциклопедичних виданнях.

\section{БІБЛІОГРА́ФІЯ}

(англ. bibliography) - перелік фахових джерел (книг, журналів, статей), що стосуються описуваного матеріалу. Бібліографія може бути структурною частиною енциклопедичної cmammi або енциклопедї. Див. також: Огляд та Опис бібліографічний.

\section{ВЕБ-ЕНЦИКЛОПЕ́ДІЯ}

(англ. web-encyclopedia) - енциклопедія в цифровому вигляді, що існує в мережі Інтернет. В.-е. створюють або на базі паперового енциклопедичного видання (шляхом адаптації матеріалу під веб-середовище), або як окремий веб-ресурс, що функціонує лише в мережі Інтернет і не має друкованих аналогів. Серед останніх виокремлюють вікі-енциклопедіі - сайти довідкового характеру, створювані спільними зусиллями необмеженої кількості зацікавлених осіб відповід- но до встановлених правил. Найвідомішим прикладом вікі-енциклопедії $\epsilon$ «Вікіпедія». В.-е. зручні з погляду пошуку інформації, зокрема дозволяють швидко знаходити матеріали за ключовим словом. Прикметною особливістю В.-е. є актуалізація інформацй (застарілі дані постійно оновлюють на відміну від друкованих видань, де актуалізація інформації забезпечується завдяки друку томів додаткових). Серед вихідних даних В.-е. - веб-адреса і роки існування іï у веб-середовищі.

\section{ВИДА́ННЯ ДОВІДКО́ВЕ}

(англ. reference book) - видання, основним завданням і призначенням якого $є$ подання матеріалу в зручній формі для швидкого отримання інформації різного характеру. Розраховано переважно на вибіркового читача. Уміщує короткі наукові або прикладні (навчальні) відомості. Серед різновидів В. д. - енциклопедія, енциклопедичний словник, енциклопедичний довідник, енциклопедичний словник-довідник, довідник, словник, посібник, путівник.

\section{ВКАЗі́ВКА}

(англ. specification) - інформаційнометодичний документ, що регулює дотримання визначеної концепцй енциклопедӥ та рекомендованої орієнтовної схеми-анкети в підготовці й написанні статей до енциклопедій різного типу.

\section{ВКЛЕ́ЙКА}

(англ. insert) - окремий відбиток ілюстративного матеріалу чи тексту, приклеєний до корінцевого поля од- 
нієї із внутрішніх сторінок енциклопедичного видання.

\section{ГА́слО}

(англ. catchword) - реєстрове слово в сло́внику енцилопедичного видання (самостійно або разом з анотацією). У ширшому значенні Г. називають заголовок енциклопедичної cmammi (самостійно чи разом із наповненням статmi).

\section{ДЕ́РЕВО ПОНЯ์ТЬ}

(англ. conception tree) - сукупність взаємопов'язаних понять із чіткою ієрархічною структурою. В енциклопедистиці подекуди вживають і термін «дерево гасел». За деревовидною схемою подають сmammi в енциклопедіях систематичних (див. також: Енциклопедія тематична). В енциклопедіях алфавітних взаємопов'язані поняття відшуковують за посилань системою (див. також: Посилання перехресне). Д. п. допомагає авторсъкому колективу та редакторам орієнтуватися щодо обсягу статей. Термін має таке найменування, оскільки його графічне зображення нагадує перевернуте дерево - корінь, або кореневий (перший, стартовий) вузол (головний понятійний елемент, від якого відгалужуються решта) розташовують зверху. Від головного та проміжних елементів можливе відгалуження одного чи більшої кількості елементів. Проміжні понятійні елементи також називають гіллям, або внутрішніми вузлами; понятійні елементи, які не мають дочірніх чкладників, - листками, або листковими (термінальними, кінцевими) вузлами.

\section{ДЕФІНі́цІЯ}

(англ. definition) - коротке логічне та науково точне визначення (тлумачення) поняття, у якому відбито найістотніші його риси. Д. вибудовують за можливістю однотипними та водночас повноцінними словниковими довідками. Вони також мають тлумачити сучасний зміст поняття без звернення до історії трансформації його розуміння суспільством. В енциклопедіях Д. є найвагомішою інформаційною одиницею. Користувач може обмежитися лише дефінітною інформацією, не читаючи всієі cmammi, і цього буде достатньо для найзагальнішого уявлення про поняття.

\section{ДО́ВІДКА ЕТИМОЛОГі́ЧНА (Етимологія)}

(англ. etymological information) лінгвістична інформація, що пояснює походження слова та його споріднені зв'язки з іншими словами тієї самої або інших споріднених мов. В енциклопедіях і словниках Д. е. подають найчастіше в дужках до іншомовних слів-заголовків.

\section{ЕКСПЕ́PTHА ОЦÍHКА CTATTÍ}

(англ. expert opinion on an article) вид редакторської роботи, метою якої є дослідження, перевірка, аналіз й оцінка наукового та іншого рівнів статті, а також підготовка обгрунтованих висновків щодо неї. До Е. о. с., зокрема й енциклопедичної, залучають експертів-фахівців відповідної галузі (див.: Наукове редагування). 


\section{ЕНЦИКЛОПЕДЙСТ}

(англ. encyclopedist) - 1) укладач енциклопедій (автор статей чи редактор видання) або науковець, який досліджує теоретичні й практичні проблеми їх укладання (фахівець з енциклопедистики). Термін «Е.» вживають від 18 ст., коли група французьких мислителів, науковців, письменників та митців почала працювати над виданням «Енциклопедія, або Тлумачний словник науки, мистецтва й ремесел» під редагуванням Д. Дідро та Ж.-Л. д’Аламбера.

2) Ерудована особа з глибокими універсальними знаннями в певній чи багатьох галузях науки й життя. Прикметні риси Е. - вченість, обізнаність (високий інтелект), начитаність. Е. вирізняється особливим мисленням, що формується на основі поєднання наукових знань (різних наук), мистецтва, філософії. Історія знає чимало науковців, художників, письменників, талант яких виявився і в науці, і в мистецтві. Е. часто називають Аристотеля, який підсумував здобутки давньогрец. філософів. Окрім знань, Е. має системне логічне мислення, аналітичні здібності та вміння робити критичні висновки.

\section{ЕНЦИКЛОПЕДЙСТИКА (Енциклопедознавство)}

(англ. encyclopedia science) - галузь наукових знань, у якій об’єктом досліджень є енциклопедичні видання Е. - наука про енциклопедії з охопленням усіх проблем їхнього створення, зокрема методології та методики укладання, класифікації, визначен- ня типових ознак тощо. Е. як окремий науковий напрям формується на основі поєднання різних наук, та найбільше - історичних (Е. відносять до спеціальних історичних дисциплін). Серед наукових проблем Е. вирізняють питання історії енциклопедичного книговидання, форм і класифікації енциклопедіü (зокрема розрізнення друкованих і електронних; універсальних, спеціалізованих, регіональних тощо); методичних засад їхнього укладання, що пов'язані з відбором матеріалів до енциклопедій, мовними особливостями написання статей, поданням інформації (фактичних даних), актуалізацією інформації в них, залученням авторів; ролі та значення енциклопедичних видань розвою суспільства тощо (див. також: Енциклопедична справа).

\section{ЕНЦИКЛОПЕДИ์ЧНА КУЛЬТУ́РА}

(англ. encyclopedic culture) - сукупність цінностей, пов'язаних зі створенням енциклопедій. Е. к. асоціюють із розвитком традицій енциклопедичної справи - 3 їі минулим та майбутнім, яке вимагає консолідації й докладання зусиль багатьох науковців, інституцій тощо, а також ретельного вивчення досвіду енциклопедичного книговидання. Значного розвитку Е. к. отримала в епоху Ренесансу.

\section{ЕНЦИКЛОПЕДИ์ЧНА ЛІТЕРАТУ́PA}

(англ. encyclopedic historical literature) - книги довідкового характеру (див.: Видання довідкові), що охоплюють як енциклопедӥ, енцикло- 
Materials to Glossary for Encyclopedia Science

педичні словники, енииклопедичні довідники й енциклопедичні словники-довідники, так і літературу, що історично передувала їм (словники, лексикони, компендіуми, зерцала тощо). До найвідомішої в світі Е. л. належать: трактат «Дисципліни» Терренція Варрона (116-27 рр. до н. е.) й «Історія природи» у 37-ми книгах Плінія Старшого (23-79 рр.), словник «Лексикон Свіди» (10 ст.), «Енциклопедія, або Тлумачний словник науки, мистецтва й ремесел» Д. Дідро та Ж.-Л. д’Аламбера, «Британська енциклопедія» тощо. В Україні до найвідоміших зразків Е. л. належать такі видання: «Ізборнік Святослава» (1073), «Лексикон...» Памви Беринди (1627), «Українська загальна енцикльопедія» за ред. I. Раковського (1930-1933), «Енциклопедія українознавства» за ред. В. Кубійовича (1949-1995), «Українька радянська енциклопедія» за ред. М. Бажана (1959-1985) тощо. Серед Е. л. найбільшою за кількістю томів нині $\epsilon$ «Енциклопедія Сучасної України» за ред. А. Жуковського, М. Дзюби, М. Железняка та ін. (станом на 2018 рік - 20 томів; готуються нові).

\section{ЕНЦИКЛОПЕДИ์ЧНА СПРА́ВА}

(англ. encyclopedia publishing) - галузь знань, що охоплює енциклопедистику, передусім ï прикладну ділянку, пов'язану з підготовкою, укладанням та виданням енциклопедіŭ (пошук авторів, написання стаmeŭ, їх редагування, а також друкування видань та їх розповсюдження тощо).

\section{ЕНЦИКЛОПЕДИЧЧНИЙ ДОВІДНЙк}

(англ. encyclopedic reference book) видання довідкове, що містить короткі відомості наукового, науково-публіцистичного або прикладного характеру про певні поняття, терміни тощо. Матеріал в Е. д. розміщують зазвичай за тематичним принципом, обсяг обмежують 1-3 томами. Більшість із них орієнтовано на широке коло читачів.

\section{ЕНЦИКЛОПЕДИЧЧНИЙ ЖАНР}

(англ. encyclopedic genre) - жанровий різновид видань довідкових, що характеризується власними засадничими рисами створення, структурою подання інформаціі, мовною стилістикою тощо. Е. ж. властивий передусім енциклопедіям та іншій енциклопедичній літературі. Водночас будь-який інший твір (напр., наукова стаття) може бути написаний за принципами Е. ж.

\section{ЕНЦИКЛОПЕДИ์ЧНИЙ сЛОвНи́к}

(англ. encyclopedic dictionary) - видання довідкове, що містить упорядкований за алфавітним або тематичним принципами перелік певних понять (слів, словосполучень), термінів тощо із поясненням їхного значення, але без широкого потрактування суті явища. На відміну від енциклопедій, в Е. с. основне смислове навантаження покладено на дефiніцію. Cmammi вирізняються лаконічністю, більшість із них має лише тлумачний характер. Історично тер- 
міном «Е. с.» позначали всі видання енциклопедичного характеру, тривалий час його вживали як синонім поняття «енциклопедія».

\section{ЕНЦИКЛОПЕДИ์ЧНИЙ словни́к-довІдни́к}

(англ. encyclopedic dictionary) - видання довідкове, що містить упорядкований за алфавітним або тематичним принципами перелік певних понять (слів, словосполучень), термінів тощо із поясненням їхнього значення та короткими додатковими відомостями про них наукового, науково-публіцистичного або прикладного характеру.

\section{ЕНЦИКЛОПЕДИ์ЧНИЙ ФОРМА́Т}

(англ. encyclopedic layout) - різновид формату видання, що визначає ширину та довжину сторінки (у міліметрах) або ширину чи довжину друкованого аркуша (у сантиметрах) енциклопедї із зазначенням частки, яку займає сторінка. Зазвичай у випускних даних вказують формат друкарського паперу та частку аркуша, при цьому потенційні відхилення в накладі не повинні перевищувати 1 мм за шириною і висотою. Під час вибору Е. ф. враховують цільове призначення енциклопедії (універсальна, дитяча, галузева, спеціалізована тощо), особливості технічного та художнього оформлення видання, фінансові можливості видавця (зокрема, високий коефіцієнт використання площі сторінки дозволяє економити папір, однак ускладнює сприйняття інформації окремими групами читачів).

\section{ЕНЦИКЛОПЕ́ДIї КОНЦЕ́ПЦІЯ}

(англ. concept of encyclopedia) - ідейний задум енциклопедіі. Е. к. є сукупністю взаємопов'язаних і взаємозумовлених ознак видання, визначених його метою, змістом, формою представлення. На основі Е. к. планують характер енциклопедії, ï формат, обсяг, залучення авторів, загальні вимоги до змісту й наповнення статей тощо. Е. к. часто коригують задля удосконалення в процесі роботи над енциклопедією. До обговорення концепції фундаментальних видань, зокрема енциклопедї національної, залучають широкі кола громадськості та засоби масової інформації.

\section{ЕНЦИКЛОПЕ́ДІЯ}

(англ. encyclopedia) - видання довідкове, що містить упорядкований за алфавітним або тематичним принципами перелік певних понять (слів, словосполучень), термінів тощо з поясненням їхнього значення. Е. - основний вид енциклопедичної літератури, подає найповніші порівняно 3 іншими довідковими виданнями відомості зі всіх чи окремих галузей знань про людину чи світ. За повнотою довідкової інформації розрізняють власне Е., енциклопедичні словники, енциклопедичні довідники, енциклопедичні словники-довідники. Основні ознаки Е.: повнота, системність і водночас лапідарність викладення інформації; науковість (висвітлення лише достовірних або максимально ймовірних фактів за 
допомогою загальновизнаних термінів і понять; уникнення сумнівних гіпотез, авторських неологізмів, прогнозів; відсутність як негативних, так і позитивних емоційних особистісних оцінок); наявність дефініцій; об'єктивність, фактологічна точність, уніфікація, схематичність оформлення статей; використання посилань системи, приміток, курсивів, довідкового апарату, карт, таблищь, ілюстрацій тощо (див. також: Енциклопедичний жанр). За характером інформації виділяють енциклопедї універсальні, енциклопедї національні, енциклопедї держави, енциклопедї спеціалізовані, енциклопедї галузеві, енциклопедї тематичні, енциклопедї проблемні (вузькогалузеві), енциклопедї регіональні, енциклопедї біографічні, енциклопедї̈персональні. За системою розташування статей - енциклопедї алфавітні, енциклопедї систематичні, енциклопедї хронологічні; за обсягом (реєстрових слів) - однотомні й багатотомні, енциклопедї короткі, малі й великі. За цільовим призначенням - популярні (для якнайширшого кола читачів), фахові (наукові, прикладні), енциклопедї дитячі. За формою подання матеріалу - паперові, енциклопедї електронні, веб-ециклопедї (онлайн-енииклопедї), енциклопедї класичні. Е. створюють переважно на основі іiі чіткої концепції (див.: Енциклопедї концепція), а також передбачають комплекс підготовчих робіт, серед яких - створення сло́вника (при цьому окремі енциклопедіі базовим підгрунтям мали не сло́вники, а повноцінні довідкові видання).

\section{ЕНЦИКЛОПЕ์ДІЯ АЛФАВІ́ТНА}

(англ. encyclopedia in alphabetical order) - енциклопедія, статті в якій розміщено за алфавітним принципом. Е. а. зручна в користуванні, забезпечує читача легким пошуком необхідної інформації. На відміну від енциклопедї систематичной, не вимагає суцільного перечитування тексту.

\section{ЕНЦИКЛОПЕ์ДІЯ БІОГРАФІ́ЧНА}

(англ. biographical encyclopedia) енциклопедія, зміст якої формують довідки про життя й діяльність видатних осіб. Укладають переважно за алфавітним принципом (іноді за тематичним або хронологічним). За характером інформаціі можуть бути загальні (про видатних діячів різних родів діяльності, напр., «Великі українці»), та часткові, зокрема регіональні (про діячів окремого регіону країни, населеного пункту, навчального закладу, товариства, заводу тощо, напр., «Енциклопедія Мукачева в іменах») та галузеві (про діячів спільного роду діяльності, напр., «Видатні вітчизняні ботаніки»). Типологічно Е. б. відносять зазвичай до енциклопедій спеціалізованих, зокрема енциклопедій галузевих або енциклопедій регіональних.

\section{ЕНЦИКЛОПЕ́ДІЯ ВЕЛИ́КА}

(англ. great encyclopedia) - енциклопедія, у якій укладачі ставлять за мету охопити якнайбільше реєстрових слів, щоб якнайповніше подати відомості з тих питань, яким іï присвячено. Е. в. належить до найповніших джерел довідкової інформації. 
Е. в. є виданнями в багатьох томах. Е. в. найчастіше бувають енциклопедіями універсальними.

\section{ЕНЦИКЛОПЕ์ДІЯ ГАЛУЗЕ́ВА}

(англ. subject encyclopedia) - енциклопедія, що містить систематизовану інформацію з певної галузі науки чи виду практичної діяльності (напр., «Енциклопедія кібернетики», «Фольклористична енциклопедія», «Географічна енциклопедія України», «Українська літературна енциклопедія», «Мала гірнича енциклопедія», «Геодезичний енциклопедичний словник»). В Е. г. відсутні терміни загального значення. Серед таких енциклопедій можуть бути вузькоспеціалізовані (напр., «Виробнича енциклопедія бджільництва»), за обсягом реєстрових слів - повними («Повна енциклопедія етикету») або короткими («Коротка банківська й комерційна енциклопедія»). Типологічно Е. г. зазвичай відносять до енциклопедій спеціалізованих.

\section{ЕНЦИКЛОПЕ́ДІЯ ДЕРЖА́ВИ}

(англ. encyclopedia of a state) - eHциклопедія, яку присвячено окремій державі (див. також: Енциклопедія національна). Залежно від характеру інформації Е. д. може належати до енциклопедій загальних (узагальнює різнорідні дані про народ, його територію, історію, діяльність, культуру, самобутність, здобутки, представників тощо, напр., «Енциклопедія Сучасної України») або енциклопедій спеціалізованих (висвітлює державу в контексті певної теми, проблеми, галузі знань, напр.,
«Енциклопедія професійно-технічної освіти України», «Енциклопедія історії України», енциклопедія «Мистецтво України»).

\section{ЕНЦИкЛОПЕ́ДІЯ ДИТЯ́чА}

(англ. children's encyclopedia) - eHциклопедія, призначена для дітей. Стиль статей в Е. д. науково-художній або науково-популярний. Фактичний матеріал, мова статей і посилань система узгоджені з особливостями вікової групи, якій призначене видання. Чільне місце в Е. д. займають ілюстрациї, які часто-густо є основним носієм змісту (зокрема у виданнях для дошкільнят).

\section{ЕНЦИКЛОПЕ์ДІЯ ЕЛЕКТРО́ННА}

(англ. digital encyclopedia) - $\mathbf{e H}^{-}$ циклопедія, яку представлено в цифровому форматі й опубліковано на електронних носіях (CDдисках) або в веб-мережі (Інтернеті). Е. е. з'явилися наприкінці 20 ст. (уперше Е. е. на дискетах було випущено в Японіï). Нині Е. е. поділяють на цифрові аналоги паперових надрукованих енциклопедій та веб-енциклопедӥ (онлайненциклопедіi). Перші можуть бути $\mathrm{CD}$-додатком до таких видань або ї окремою редакцією (напр., з відредагованим, оновленим і доповненим новим матеріалом). Особливість других - перманентна актуалізація інформації. Крім цього, цифрові відповідники паперових видань можуть виглядати як електронна копія з повним збереженням не лише змісту видання, а й форми (напр., комп’ютерний оригінал- 
Materials to Glossary for Encyclopedia Science

макет у форматах PDF, DjVu, FB2 тощо). Аналогами паперових видань можуть бути й такі Е. е., які мають свою форму розміщення й подання довідкового матеріалу, адаптованого під особливості цифрового формату - із власним інтерфейсом, архітектонікою, навігацією, пошуковою системою тощо. Е. е. такого типу вирізняються широкими мультимедійними особливостями: вони містять «живі» ілюстрації - матеріали відео-, аудіо- і кінозйомок, що відтворюють об'єкти в повноті кольорів, звуків, динаміки. Ще однією прикметною рисою Е. е. є окремий спосіб подання інформації - гіпертекст, який характеризується нелінійною архітектурою викладу матеріалу й забезпечує миттєвий перехід від однієї статті до пов’язаної з нею іншої. Цифровий формат подання енциклопедичної інформації відкрив нові перспективи в розвитку видань цього жанру. Зокрема, в мережі Інтернет з'явилися різноманітні онлайн-енциклопедії, найважливішою особливістю яких є мобільність щодо оновлення застарілої інформаціі. Будь-яку енциклопедію, що публікують на CD-носієві, можна адаптувати під веб-енциклопедію, і навпаки. Вихідні дані Е. е. на CDносієві охоплюють дату опублікування, видавця тощо, натомість вебенциклопедії, які не мають паперових оригіналів, - лише веб-адресу і роки існування в мережі.

\section{ЕНЦИКЛОПЕ์ДІЯ ЗАГА́ЛЬНА}

(англ. general encyclopedia) - те саме, що енциклопедія універсальна.

\section{ЕНЦИКЛОПЕ์ДІЯ КЛАСИ์ЧНА}

(англ. classic encyclopedia) - енциклопедія, яка стала зразком для наслідування у створенні енциклопедичних видань. Найчастіше Е. к. це всесвітньовідомі енциклопедії минулих епох, що мали суттєвий вплив на розвиток енциклопедичної справи. Напр., такою є 35-томна «Енциклопедія, або Тлумачний словник науки, мистецтва й ремесел» (1751-1780), яку було створено за систематичним принципом подання наукових відомостей в епоху Просвітництва у Парижі під керівництвом Д. Дідро та Ж.-Л. д’Аламбера. У тритомній К. е. «Британська енциклопедія (17681771), виданій в Единбурзі, вперше застосовано алфавітне розміщення cmameŭ як більш зручне для орієнтування в системі знань. В епоху Просвітництва енциклопедї набули вдосконалення; саме вони сформували основні риси, принципи та моделі сучасних енциклопедичних виданъ. Найвизначніші Е. к. цього періоду - «Енциклопедія Брокгауз» (1796-1808) та «Великий універсальний словник XIX ст.» П. Ларусса (1866-1874). У XX ст. низка Е. к. минулих епох перевидавалася, розширювалася, вдосконалювалася, видозмінювалася в інші видання й форми. Наприклад, «Велику енциклопедію Ларусса» (1960-1964), що продовжила традицію згаданого вище універсального словника, створили в елітній, повній і базовій версіях. XXI ст. відзначається появою енциклопедій електронних, у зв'язку з чим поняття «Е. к.» набу- 
ло додаткового відтінку значення, асоційованого з друкованими енциклопедичними виданнями, в яких дотримано традиційних жанрових ознак. Методологічні підходи й технологіі підготовки матеріалів Е. к. найчастіше застосовують в укладанні енциклопедій універсальних. Див. також: Енциклопедї концепція.

\section{ЕНЦИКЛОПЕ́ДІЯ КОРО́ТКА}

(англ. concise encyclopedia) - eHциклопедія, що подає лише найосновніші терміни, поняття, явища 3 тих питань, висвітленню яких ї̈ присвячено. Енциклопедія може бути короткою не лише через оптимізований перелік гасел, а й за рахунок того, що статтям у ній властиві стислість і лаконічність. Е. к. часто є скороченою версією більш повного видання, зокрема багатотомного. Проте Е. к. може бути й першим етапом створення більш широкого видання. Напр., «Шевченківський словник» у 2-х томах став основою під час створення фундаментальної 6-томної «Шевченківської енциклопедії». Е. к. найчастіше належить до енциклопедій галузевих.

\section{ЕНЦИКЛОПЁДІЯ НАЩІОНА́ЛЬНА}

(англ. encyclopedia of a nation) різновид енциклопедї держави. Визначальною рисою Е. н. є тематика, пов'язана з відображенням історї та сучасного стану народу, природного багатства, економіки, державного та суспільного устрою, культури (освіти, науки, мистецтва, 3MI, книговидання, фізичного виховання тощо), філософії та релігіі, охорони здоров'я, міжнародних зв'язків держави. Е. н. має важливе для держави значення, зокрема в контексті утвердження національної самосвідомості ii громадян, патріотизму. Належить здебільшого до багатотомних видань (напр., «Енциклопедія Сучасної України») і є своєрідною «візитівкою» держави. Нині Е. н. створюють переважно в паперовому (книжковому) і водночас електронному форматах (див.: веб-енциклопедія).

\section{ЕНЦИКЛОПЕ́ДІЯ ПЕРСОНА́ЛЬНА}

(англ. encyclopedia of a person) - енцииклопедія, яку присвячено одній особі - письменнику, науковцю, митцеві, спортсменові тощо. Здебільшого Е. п. є завершальною формою грунтовного вивчення діяльності визначної особи. Типова Е. п. поєднує біографічну інформацію 3 науковими розвідками про особу (дослідження ї місця й ролі в тій галузі знань, до якої належить особа). Е. п. часто складається з передмови, розлогого нарису про особу, словникової частини (гасла відповідають назвам творів, оточенню, персонажам тощо), літопису життя й творчості особи, бібліографї, іменного покажчика, списків основних скорочень та ілюстрацій. Напр., Е. п. у галузі літератури особливої цінності набувають у поєднанні з повним виданням творів особи. Прикладами Е. п. є «Шевченківська енциклопедія» та «Франківська енциклопедія». Типологічно Е. п. зазвичай відносять до енциклопедій спеціалізованих. 


\section{ЕНЦИКЛОПЕ́ДІЯ ПРОБЛЕ์МНА (Енциклопедія вузькогалузева)}

(англ. subject encyclopedia) - piзновид енциклопедї спеціоналізованої, підвид енциклопедї галузевої або енциклопедї регіональної, у якій зібрано матеріали $з$ конкретної проблеми, що становить предмет розгляду певної частини окремої галузі (напр., «Козацька старшина Гетьманщини», «Енциклопедія аграрних фінансів», «Визначні пам'ятки Києва»). Е. п. містить релевантну термінологічну базу з окресленої проблеми.

\section{ЕНЦИКЛОПЁДІЯ РЕГІОНА́ЛЬНА}

(англ. regional encyclopedia) - eHциклопедія, що містить відомості про всі чи окремі визначені аспекти певного регіону. В типологічному плані Е. р. відносять до енциклопедій спеціалізованих. Найчастіше Е. р. присвячують окремому регіону країни - відповідно до адміністративно-територіального (населений пункт, район, область) або історико-географічного (напр., Слобожанщина, Галичина, Волинь, Кривбас, Донбас) поділу. До Е. р. належать також видання, присвячені навчальним закладам, установам, організаціям, товариствам, музеям, спілкам, місцевим пам'яткам природи тощо (напр., «Енциклопедія НТШ», «Енциклопедія Львівського національного університету імені Івана Франка». За інформативністю Е. р. можуть бути загальними (ті, що охоплюють різноманітні знання про регіон, відображають його колорит, виразні особливості, напр., енциклопедичні довідники «Полтавщина», «Чернігівщина»), вузькогалузевими (ті, що висвітлюють лише певну галузь чи практичну діяльність регіону, напр., «Морская энциклопедия Одессы», «Православная энциклопедия Харьковщины») та біографічними (ті, що інформують про видатних уродженців, відомих людей, які жили та працювали в регіоні, напр., «Сумщина в іменах»; див. також: Енциклопедія біографічна). Формально до Е. р. можна віднести енциклопедії, присвячені тій чи іншій країні, кільком країнам, які межують між собою і мають багато спільного, або окремим частинам світу. Див. також: Енциклопедія держави, Енциклопедія національна.

\section{ЕНЦИКЛОПЕ́ДІЯ СИСТЕМАТИ́ЧНА}

(англ. conceptual encyclopedia) - eнциклопедія, статті якої укладено за логіко-тематичним (ієрархічним) принципом. На відміну від енциклопедй алфавітної, у якій статті розташовують за алфавітом, та енциклопедї хронологічної, де статті корелюють із датою, у Е. с. статті групують відповідно до деревовидної структури (див.: Дерево понять). Енциклопедії з таким способом організації не містять інверсій у назвах cmameй, їхнім обов'язковим елементом є зміст, подекуди додають різноманітні алфавітні покажчики. Кожний том Е. с. присвячено одній або кільком темам, що в сукупності 
висвітлюють закладену в концепції енциклопедіі тематику. Статті в Е. с. можуть бути досить розлогими, сягаючи розміру окремого розділу книги. За ієрархічним принципом створюють переважно енциклопедї тематичні (вживають також як тотожне поняття до Е. с.). Іноді в такий спосіб формують один із томів алфавітних енциклопедій (напр., 17-й том «Української радянської енциклопедії) або укладають частину томів за ієрархічним принципом, а іншу - за алфавітом (напр., «Енциклопедія українознавства» поділяється на тематичну та словникову частини). Статті веб-енциклопедіŭ та енциклопедій електронних за бажанням користувача можна відбирати за тематиками або за алфавітом, а подекуди - й за хронологією. У Е. с. переважно не вміщують статей-персоналій або подають їх у незначній кількості. Серед ін. назв енциклопедія з деревовидним розташуванням статей, ієрархічна енциклопедія, логічно-тематична енциклопедія.

\section{ЕНЦИКЛОПЕ์ДІЯ СПЕЦІАЛІЗО́ВАНА}

(англ. subject encyclopedia) - енциклопедія, яку присвячено окремій частині знань про людину чи світ. Е. с. протиставляють енциклопедї універсальній. Якщо універсальні енциклопедії лише згадують або ознайомлюють читача 3 тією чи іншою тематикою, то Е. с. грунтовно подають весь спектр відповідної інформації про неї. Серед Е. с. виокремлюють три основні різновиди: енциклопедія галузева, енциклопедія регіональна та енциклопедія персональна. У свою чергу, серед галузевих чи регіональних енциклопедій виділяють енциклопедію проблемну (вузькогалузеву) та енциклопедію біографічну.

\section{ЕНЦИКЛОПЕ์ДІЯ ТЕМАТИ์ЧНА}

(англ. thematic encyclopedia) - енциклопедія, яку присвячено одній темі (всім ऑï аспектам). В окремий тип Е. т. виділяють через тип розміщення статей за деревовидною схемою, тобто за ієрархічним принципом (див.: Дерево понять). Тому доволі часто поняття «Е. т.» вживають як синонім до «енциклопедія систематична». Тематика, яку висвітлюють Е. т., може охоплювати науковий, літературний, мистецький та інші напрями, історичні події чи історичні феномени, вулиці, місцевості, мікрорайони населеного пункту, пам'ятки чи групи споріднених пам'яток архітектури, історії, монументального мистецтва, географічного об’єкту, культурного, релігійного, спортивного та іншого закладу, етикет в громадських місцях, за столом, здоров'я сім”i, жінки, чоловіка, дитини, краси жінки, дівчинки тощо. Е. т. можуть містити велику кількість ілюстрацій на відповідну тему. За характером інформації Е. т. найчастіше є енциклопедією галузевою або ї підвидом - енциклопедією проблемною (вузькогалузевою), що складається $з$ кількох томів. Причому кожен том присвячено окремій темі, хоча всі вони об'єднані спільною тематикою (напр., енциклопедія «Країни світу і Україна»). 


\section{ЕНЦИКЛОПЕ́ДІЯ УНІВЕРСА́ЛЬНА}

(англ. universal encyclopedia) - енциклопедія, що охоплює все коло найважливіших знань про людину і світ. Укладають переважно за алфавітом (винятком можуть бути енциклопедї дитяці; див. також: Енциклопедія алфавітна), оскільки містить значну кількість непов'язаних між собою статей. Інколи за деревовидною схемою створюють окремі томи, присвячені конкретній темі (див.: Дерево понять, Енциклопедія систематична). На відміну від інших видів енциклопедій в Е. у. обов'язковим $\epsilon$ подання статейперсоналій. Е. у. переважно є енциклопедіями великими. Вони призначені як для фахівців різних галузей, так і для широкого загалу, оскільки подають наукову інформацію в доступній формі. Е. у. може висвітлювати всі сфери людської діяльності глобально або на рівні держави (див.: Енциклопедія національна), як від найдавніших часів і до сьогодення (напр., «Велика українська енциклопедія»), так і за певний проміжок часу (напр., «Енциклопедія Сучасної України», яка висвітлює 20 - поч. 21 ст.). У типологічному плані Е. у. протиставляють енциклопедӥ спеціалізованій.

\section{ЕНЦИКЛОПЕ́ДІЯ ХРОНОЛОГІ́ЧНА}

(англ. encyclopedia in chronological order) - енциклопедія, статті в якій укладено за хронологічним принципом. Заголовками таких енциклопедій є дати - до них прив'язана вся інформація. У вигляді Е. х. створю- ють переважно енциклопедії, присвячені історії певного регіону (див. також: Енциклопедія регіональна) або історії науки, наукового напряму. Хронологічне розташування матеріалу дає можливість огляду фактичної послідовності у становленні державності та формуванні нації, розвитку історичних подій на визначеній території, окремих наукових ідей, тих чи інших світоглядних концепцій, соціальних рухів тощо. Серед прикладів перших праць української енциклопедичної літератури хронологічного характеру - літописи. Див. також: Енциклопедія алфавітна та Енциклопедія систематична.

\section{ЗА́голо́воК}

(англ. title) - 1) назва статmi в енциклопедичному виданні. Формально є одним словом чи словосполученням; висвітлює сутність теми, ідеї, предмет, об'єкт, якому присвячено статтю. 3. прийнято виділяти видозміненим шрифтом (напр., напівжирним) та наголошувати (якщо 3. складається з кількох слів, то наголос ставлять на кожному з них, окрім односкладових слів). Багатотомні енциклопедії, довідники, словники та інші видання, побудовані за абеткою, окрім основної назви, містять заголовкові літери. Основні функції 3.: структурування значного за обсягом матеріалу, забезпечення зручності в пошуку вибіркової інформації. Додатковий 3., який пояснює та доповнює основний, називають підзаголовком. Найчастіше його подають у круглих дужках або розміщують окремим рядком, надрукова- 
ним відносно основного 3. шрифтом меншого кегля. Якщо 3. складається з кількох слів, то часто вживають інверсію задля того, щоб першим було ключове слово для того чи іншого понятТя.

2) Назва тематичного розділу в енциклопедичних виданнях із логічнотематичним поданням статей (див.: Енциклопедія систематична, Енциклопедія тематична).

\section{MICT}

(англ. contents) - 1) сутність викладеного в енциклопедичній статті. Основна структурна частина статті.

2) Перелік складових частин енциклопедії - заголовків всіх або найзначніших частин видання. З. розміщують на початку або в кінці. У З. зазначають також початкові сторінки, на яких уміщені відповідні частини. Він виконує довідково-пошукову й інформаційно-пояснювальну функції. 3. є обов'язковим елементом довідково-енциклопедичних видань 3 логічно-тематичним розташуванням статей (див.: Енциклопедія систематична, Енциклопедія тематична). В енциклопедіях алфавітних інколи друкують перелік заголовків головних (найбільших) статей із зазначенням авторів і сторінок, карт й ілюстрацій, рідше - перелік заголовків усіх статей.

\section{ІКОНОГРА́ФІЯ}

(англ. iconography) - 1) наукове вивчення й опис різних видів зображень певної особи, події, місцевості в живописі, скульптурі, графіці, фотографії тощо.

2) Сукупність різних видів зображень певної особи, події, місцевості в живописі, скульптурі, графіці, фотографії тощо. Залежно від концепції та типу енциклопедичних видань їхні укладачі поєднують текстовий контент із певною кількістю іконографічного матеріалу. Див.: Ілюстрація, Фотографія.

\section{ІЛЮСТРА́цІЯ}

(англ. image) - наочне зображення, що супроводжує текст статті з метою візуалізації змісту. I. є одним із видів друкованої графіки, частиною художнього оформлення видання з обкладинкою, заставками, кінцівками, орнаментальним декором і шрифтовим набором. До I. належать: малюнки, фотографї̈, репродукції, карти, креслення, схеми, діаграми. I. не лише унаочнюють зміст стаmmi, а й доповнюють ï виклад, поглиблюють інформативність поданого матеріалу. Часто І. дає можливість суттєво скоротити енциклопедичну статтю. Ïi розміщують переважно на тій самій сторінці, що й текст із посиланням на неї, або на розвороті з таким текстом. Усі I. оформлюють із підписом, узгодженим як із зображенням, так і з текстовим матеріалом. Ступінь насичення видання I. вимірюють у відсотках. Середній ступінь насичення I. в енциклопедіях $-15 \%$.

\section{IHBÉPCIЯ В НÁЗВАХ CTATÉЙ}

(англ. inversion in article titles) - зміна звичайного порядку слів у назві 
статей (див. також: Заголовок). Здійснюють з метою висунення на перше місце слова, що має в назві суттєвіший зміст, та алфавітного групування статей за однокореневими словами, що мають змістову спорідненість (напр., «Геологів України спілка», "Геологічних наук Інститут НАНУ», «Геологія інженерна»). Інверсовані назви полегшують пошук відповідної інформаціі, рубрики, статті тощо, сприяють процесу встановлення систематизації знань. Іноді для зручності пошуку подають статmі відсильні, напр., за таким зразком: «Медицина космічна -див. Космічна медицина».

\section{ІНІЦІА́Л}

(англ. initial cap) - 1) заголовна літера книги, нового розділу, частини або абзацу, зазвичай виділена шрифтом більшого розміру. Інша назва - буквиця. I. може бути набірним (переважно крупнокегельна літера тієї самої гарнітури шрифту, якою надруковано основний текст), рисованим або гравійованим; іноді композиційно декорованим, орнаментованим і підкріпленим сюжетною ілюстрацією. Використання буквиць на початку cmameŭ на одну літеру набуло поширення в енциклопедичній літератуpi. У наступному томі багатотомної енциклопедй, який продовжує цикл статей на ту саму літеру, буквиці не розміщують.

2) Прописна перша літера імені, по батькові та іноді прізвища. В енциклопедичній справі вживають під час зазначення автора статті, а також у статті, зазначаючи тих чи інших осіб, роблячи підписи до іконографї або створюючи перелік бібліографічних джерел.

\section{KÁPTA}

(англ. мар) - зменшене та генералізоване загальне зображення тих чи інших територій земної поверхні. К. відображають розміщення та взаємозв'язки об'єктів і явищ у прийнятій системі умовних знаків. Для них також характерний математичний закон побудови, тобто використання картографічної проекцїі, що дає змогу перейти від сферичної поверхні Землі до площини. К. класифікують за масштабом (плани, велико-, середньо- і дрібномасштабні), територіальним охопленням (напр., зоряного неба, природного об'єкта, населеного пункту) і змістом (загально-географічні: топографічні й оглядово-топографічні; тематичні: природничі, суспільних явищ, суспільно-природничі; вузькоспеціалізовані, напр., навігаційні, кадастрові, технічні, проектні). В енциклопедіях ix використовують як ілюстративний матеріал (див.: Iлюстрація), подають переважно до статей про країни, області, райони, з природничо-географічної, демографічної історичної та інших тематик.

\section{КОЛЕ́ГІЯ РЕДАКЦІ́ЙНА}

(англ. editorial board) - дорадчий i керівний орган, який розробляє енциклопедї концепцію та визначає формат енциклопедичного видання, допомагає видавництву або друкованому органу оцінити та вибрати 
необхідні cmammi, а також частково їх опрацювати безпосередньо перед редагуванням, верстанням і друком. К. г. формується із групи авторитетних людей - провідних фахівців окремої галузі. Їхні прізвища зазначають у вихідних даних видання, завдяки цій інформації читач може складати перше враження про його якість. Редколегією керує редактор головний, або голова, іноді - кілька співголовів, до їі складу входять відповідальний секретар, або відповідальний редактор, наукові редактори. В енциклопедичних виданнях К. г. розробляє концепцію, визначає орієнтовні обсяги матеріалу в знаках, затверджує перелік гасел (див.: словник), рекомендує авторів для написання статей, здійснює оцінювання матеріалів тощо.

\section{компІля́цІя}

(англ. compilation) - один із методів написання cmammi, який грунтується на запозиченні матеріалів, думок, досліджень з опублікованих джерел різних авторів. Метод К. вимагає посилання на першоджерело, з якого запозичено інформацію.

\section{КОНСУЛЬТА́НТ НАУКО́ВИЙ}

(англ. scientific adviser) - фахівець, що здійснює наукову експертизу та консультації в підготовці матеріалів для енциклопедичного видання. В енциклопедіях К. н. надає поради 3 проблемних питань свого фаху укладачам енциклопедичного видання, які опрацьовують оригінал авторсъкий.

\section{КРИТЕ́РIї ВІДБО́РУ}

(англ. selection requirements) - ознаки, за якими відбирають, визначають, оцінюють персоналї, події, явища, об'єкти, інституції тощо. К. в. статей ретельно прописують в енциклопедї концепцй. К. в. інформацї представлення фактів, подій, постатей правдиво, повно, об’єктивно, виважено, збалансовано, незаангажовано, без ідеологізованих оцінок, $з$ адекватними характеристиками. Визначаючи масштаб енциклопедичного видання (див.: Обсяг енциклоnедї), зважають на ступінь удокладнення матеріалу. Напр., для загальних енциклопедій К. в. інформації зі спеціальних галузей знань є такі орієнтири, як «загальне-конкретне», «важливіше-менш важливе». В енциклопедіях явища, осіб минулого й сучасного намагаються представляти симетрично та відповідно до історичних наслідків, ролі в істоpii, віддаючи перевагу особистостям iз позитивним внеском у різні сфери діяльності. Відбираючи персоналії, зважають насамперед на формальні ознаки (особи, які займали найвищі посади у важливих установах; наукове чи мистецьке звання; членство у професійних спілках; наявність державних нагород), які не варто ігнорувати, проте вони не можуть бути абсолютними нормами. На основі експертних оцінок консультантів наукових, членів редколегіі, через громадське обговорення сло́вників здійснюють альтернативний принцип підходу до відбору персоналій, наголошуючи на їхньому внеску в розвиток науки, техніки, мистецтва, 
літератури, політики та громадського життя, актуальності чи історичній значимості спадщини. Важливим $€$ принцип вибірковості (напр., особи, які народилися, навчалися чи померли в Україні за певний період; репресовані; дослідники української тематики, популяризатори української культури в діаспорі). К. в. є також відомість, резонанс, визнання, цитованість, думка критиків. Особливу увагу приділяють явищам, процесам, поняттям, що характеризують добу сучасності (хоча сучасний матеріал створює певні труднощі під час добору).

\section{НА́КЛАД}

(англ. run) - загальна кількість примірників друкованого видання, виготовлених поліграфічним підприємством. Зазвичай Н. зазначають у вихідних даних видання; визначають видавці чи замовники. Види Н.: пробний (первісний, для вивчення попиту на видання), разовий (наклад одного випуску, номера, тому періодичного видання), річний (сукупність накладів видавництва, країни за рік; загальна кількість усіх випусків періодичного видання за рік), додатковий, загальний (сукупність накладів видань, випущених видавництвом за певний період), середній (частка від ділення суми накладів усіх видань на їхню кількість). Розрізняють Н. малі (до 15 тис. примірників), середні (до 100 тис.) та масові (понад 100 тис.; у зв’язку зі значними обсягами поліграфічних робіт друкують частинами). Напр., одна 3 найперших енциклопедій у світі «Ен- циклопедія, або Тлумачний словник науки, мистецтва й ремесел» мала наклад 4250 примірників, натомість одна 3 найбільших енциклопедій «Британіка» у 32-томному виданні 1988 року мала наклад 200 тис. примірників. «Українська радянська енциклопедія - 80 тис. (1-ше видання) i 50 тис. (2-ге видання) примірників; «Енциклопедія Сучасної України» 10 тис. примірників.

\section{НАПÓВНЕННЯ СТАTTÍ}

(англ. content) - кількість і характер інформації у статті; внутрішньостатейна інформація готується автором чи редактором відповідно до вимог видання (див.: Енциклопедї концепція). Н. с. залежить від обсягів стаmей, запланованих у сло́внику. Див. також: Оригінал авторський.

\section{НАУКО́ВО-РЕДАКЦІ́ЙНА РА́ДА}

(англ. scientific editorial board) - колегіальний орган, що формує методичну групу для розроблення енциклопедї концепциї та визначення орієнтовних обсягів статей для кожної галузі знань з урахуванням досвіду підготовки енциклопедій, особливостей національного розвитку та потреб сучасного суспільства, досягнень науки, появи нових галузей знань тощо.

\section{ОБКЛА́ДИНКА}

(англ. cover) - обов'язковий конструктивний елемент (з одного цілісного аркуша цупкого паперу 3 твердих чи м'яких палітурних матеріалів) зовнішньої форми енци- 
клопедччного видання, яким покривають книжковий блок; чотири зовнішні сторінки, де розміщено основні інформативні дані для читача (назву, відомості про серію, вихідні дані тощо). На О. з рекламною метою можуть виносити суттєву для продажу книги інформацію, здатну привернути увагу покупця, - заголовки чи марки популярних серій, місце випуску, назву видавництва, основні заголовки, цитати. О. бувають простими (з однієі деталі), складеними (з двох і більше), ілюстрованими, декоративними, шрифтовими (мальованими, набірними), гнучкими. Книги в О. розраховані на незначний термін експлуатації при інтенсивному використанні чи на середній при невеликій інтенсивності користування (довідкові книги з товщиною блоку переважно до 40 мм). Для підвищення захисту, міцності та покращення зовнішнього вигляду книги О. лакують або ламінують.

\section{ОБРО́БКА ІЛЮСТРА́ЩІЙ}

(англ. image editing) - перетворення початкового зображення за допомогою спеціальних комп'ютерних програм із метою підвищення якості ілюстрацій та забезпечення їх придатності для оптимального розміщення в тексті cmammi. O. і. передбачає растрування, кольороподіл, градаційну й колірну корекцію тощо.

\section{О́БСЯГ ЕНЦИКЛОПЕ́ДІї}

(англ. size of encyclopedia) - кількісна характеристика енциклопедичного видання. Технічно О. е., як і будь-якої іншої книги, вимірюють кількістю авторських аркушів, друкованих аркушів або обліково-видавничих аркушів. Змістовно О. е. оцінюють за кількістю гасел. Напр., 17-томна «Українська радянська енциклопедія» містить 45000 гасел, 12-томна «Українська радянська енциклопедія (2-ге видання) - 50000 гасел, 30-томна «Большая советская энциклопедия» (3-тє видання) 95270 гасел, 32-томна «Британіка» (перевидання 2007 року) - 65000 гасел.

\section{о́БСЯГ СТАТТі́}

(англ. article size) - орієнтовна кількість знаків тексту чи сторінок визначеного шрифту, що залежить від ступеня удокладнення понять, розділів, явищ, персоналій, наявності бібліографї̈ та ілюстративних матеріалів. На О. с. орієнтують автора під час замовлення їі підготовки. Відповідно до обсягу cmammi умовно поділяють на великі (розлогі), середні та малі (короткі). В основі загального орієнтира О. с. - важливість явищ, понять, персоналій у відповідному тематичному блоці. О. с. визначають під час випрацювання енциклопедичних концепцій, розділяючи статті на кілька категорій, кількість яких може варіюватися. Перша категорія (обсяг до 100 тис. знаків) - комплексні та найбільші самостійні науки (історія, фізика, біологія і т. п.), основні види мистецтва (література, живопис тощо), найважливіші історичні епохи, країни; 2-а (30-50 тис.) - науки, значні наукові та науково-технічні проблеми, жанри й види літератури i мистецтва, столиці; 3-я (10-30 тис.) - 
найбільші одиниці в певній науці чи галузі господарства, найважливіші види корисних копалин, найбільші елементи рельєфу, види військ, найбільші міста світу, найбільші етноси, мови і писемності, археологічні культури, корифеї науки, мистецтв; 4-а (3-10 тис.) - наукові дисципліни, важливі наукові поняття, терміни, вагомі природні об’єкти, основні види тварин і рослин, визначні історичні події, видатні діячі науки та мистецтва, основні види спорту, машини, транспортні засоби, великі міста; 5-а (1-3 тис.) - найбільша за кількістю статей категорія, охоплює наукові поняття, відомих діячів науки й мистецтва, найважливіші пам'ятники культури і мистецтва, окремі природні об’єкти, тварин, рослини, мінерали, гірські породи, хімічні елементи, прилади, пристрої, підприємства, театри, ВНЗи тощо; 6-а (до 1 тис.) спеціальні наукові та науково-технічні терміни, терміни в галузі фінансів і бізнесу, правові терміни, деталі машин, механізмів, мінерали і дрібні природні об'єкти, наукові і культурно-освітні організаціі, виконавські колективи, побутова техніка, види тканин, одяг, біографічні довідки; 7-а (50-100 знаків) - статті з посиланями. О. с. про персоналії залежить від внеску діяча, значення особистості, ï ролі в історї чи галузі діяльності. 1-а категорія (10-30 тис. знаків) найвидатніші історичні постаті, діячі науки, культури всіх часів і народів, які отримали загальносвітове визнання; 2-а (3-10 тис.) - видатні політичні й культурні діячі, науковці; 3-я (1-3 тис.) - відомі діячі, які зробили значний внесок у розви- ток науки, мистецтва, політики; 4-а (до 1-ї тис.) - статті словникового типу, до яких належить значна кількість біографій. Розміри статей-персоналій не повинні перевищувати 5-ти сторінок; винятки бувають, коли йдеться про найбільші постаті історії, науки, літератури, мистецтва. О. с. про фундаментальні поняття, розділи науки, галузі діяльності, природні, історичні, суспільні, політичні та інші явища - до 5-6-ти сторінок; про конкретніші, спеціальні терміни, події - до 1-ї. В енциклопедіях від О. с. залежить ступінь удокладнення, відбір матеріалів, наявність другорядних фактів і творчих характеристик. Співвідношення масштабу оповіді про схожих за рівнем величі діячів, які належать до різних галузей, обов'язкова умова під час роботи над біографічним розділом. Якщо про видатних діячів збереглося мало відомостей, то О. с. буде меншим за бажаний. На О. с. біографічної статті впливає також наявність у сло́внику окремих статей про вчення, теорії, відкриття, закони, формули і т. д., створених тим чи іншим діячем. Збільшення кількості статей зумовлює зменшення їхнього обсягу, що спонукає шукати прийнятну пропорцію, де вирішальним має бути практичний підхід, пов'язаний із майбутнім попитом на видання якомога ширшого кола читачів. Збільшення списку статей загрожує тим, що дуже стисла стаття зі спеціальної галузі знань (як дуже скорочений варіант статті зі спеціальної енциклопедіі) не задовольнить спеціаліста, а статистика звернень до такої статті з боку неспеціаліста буде занизькою. 


\section{О́ГЛЯД БІБЛІОГРАФІ́ЧНИЙ}

(англ. bibliographic book) - 1) один iз видів довідкової літератури, що становить собою вечерпний перелік наукових публікацій та документів із певної галузі знань. О. б. призначені переважно для вчених, фахівців, керівників.

2) Інформаційне видання у вигляді зв'язних характеристик про друковану продукцію, об’єднаних за типом і видами цієї продукції, персоналіями, тематикою тощо.

\section{ОНЛА́ЙН-ЕНЦИКЛОПЕ์ДІЯ}

(англ. online encyclopedia) - те саме, що веб-енциклопедія (див. також: Енциклопедія електронна).

\section{О́ПИС БІБЛІОГРА́ФІЧНИЙ}

(англ. bibliographic description) - cyкупність головних уніфікованих за складом і послідовністю ідентифікаційних відомостей (прізвище та ім'я автора, назва твору, місце і рік видання, кількість сторінок чи конкретна сторінка, на яку зроблено посилання в тексті) про друкований твір, його частини, групу творів або невиданий документ, необхідних для розпізнавання й пошуку, поданий у єдиній системі умовних знаків. О. б. може бути коротким, повним, розширеним, міжнародним. Послідовність і систему умовних знаків, набір обов’язкових елементів О. б. в Україні визначено у ДСТУ ГОСТ. Втім кожна редакція може створювати власні правила для О. б., напр., з метою полегшення сприйняття читачами бібліографічної інформацї.

\section{ОРИГІНА́Л А́ВТОРСЬКИЙ}

(англ. author's original) - 1) авторський текст статті (машинописний чи рукописний), написаний відповідно до встановлених редакцією вимог, чи окремі його матеріали (напр., фотографї, ілюстрацї) про персоналію, об’єкт, поняття, явище, напрям тощо. О. а. є вихідним джерелом для редагування енциклопедичної статті, він зберігається в архіві редакціі. Див. також: Оригінал видавничий.

2) Заповнена анкета зі збирання первинної інформацї для підготовки статті (див.: Анкетування).

\section{ОРИГІНА́Л ВИДАВНИ์ЧИЙ}

(англ. publisher's original) - проаналізований та опрацьований редактором ориаінал авторський, доповнений зовнішнім оформленням та розмічений для поліграфічного виконання. О. в. - повний проект видання, основа для виготовлення оригіналу-макету видання. Див. також: оригінал авторсъкий.

\section{ОРИГІНА́Л-МАКЕТ ВИДА́ННЯ}

(англ. book layout) - підписаний до тиражування, роздрукований як зразок і підготований для перенесення тексту в друковану форму оригінал видавничий, сторінки якого збігаються зі сторінками майбутньої книги. О.-м. в. складають за допомогою комп'ютерної видавничої системи. Переданий у друкарню О.-м. в. унеможливлює здійснення авторських і видавничих правок під час виготовлення друкарської форми. 


\section{ОФО́РМЛЕННЯ ВИДА́ННЯ}

(англ. book design) - подання змісту енциклопедії як єдиної цілісної композиціі видання за допомогою художніх та поліграфічних засобів. Зовнішнє О. в. - виконання зовнішніх (палітурки, суперобкладинки, форзаца, футляра), внутрішнє оформлення внутрішніх (титула, початкової, проміжної та кінцевої сторінок, ілюстрацій) елементів видання. За характером використаних засобів виділяють художнє (охоплює зовнішнє оформлення, ілюстрації, систему книжкових прикрас) і технічне (типові набірні засоби) оформлення.

\section{ПЕРЕДМО́ВА}

(англ. foreword) - розміщена перед основним текстом допоміжна, службова частина anapamy видання, де описово пояснено читацьке й цільове призначення, особливості видання (структуру, склад і характер матеріалу, концепцію, часові межі, критерї відбору, відомості про авторсъкий колектив тощо). У П. висвітлено значення теми енциклопедӥ, особливості змісту й форми книги, джерела написання тощо. П. готує читача до сприйняття видання, формує уявлення про нього. П. в енциклопедіях можуть подавати різними мовами.

\section{пі́дпис}

(англ. image tittle) - текст під ілюстрацією, який пов'язує иї з основним текстом сmammi, визначає тематичний зміст.

\section{ПОЗНА́ЧЕННЯ УМО́ВНI}

(англ. symbols) - розроблені скорочення для записів описів бібліографічних, позначки для заміни словесного напису під ілюстрацї. Для спрощення сприйняття картинки розшифрування П. у. подають у підрисунковому підписі (експлікаціі) чи в основному тексті.

\section{ПОСИЛА́ННЯ (відсилання)}

(англ. reference) - 1) словесна або цифрова вказівка на джерело, що роз'яснює, уточнює або доповнює відомості, подані в основному тексті видання. Назву документа, на який дають П., друкують курсивом або позначають його за допомогою цифри чи символа (*), цей документ часто вміщують у примітці.

2) Елемент покажчика видання (змісту, списку літератури та ін.), який позначає місце у тексті видання (сторінку, розділ, таблицю та ін.), де наведено відомості, пояснені докладно.

3) Запис, який переадресовує читача до іншого видання, фрагмента тексту, ілюстраціі, таблиці, формули, додатку, параграфа тощо.

\section{ПОСИЛА́ННЯ ПЕРЕХРЕ́СНЕ}

(англ. cross reference) - вказівка на взаємозв'язок частин (фрагментів) тексту, які пояснюють і доповнюють одна одну (в прямій та зворотній послідовності). Застосовують П. п. на заголовки, виноски, закладки, назви, пронумеровані абзаци тощо, але лише в межах однієї статті. 


\section{ПОСИЛА́НЬ СИСТЕ́МА (відсилань система)}

(англ. system of references) - організована певним чином сукупність різноманітних посилань, покликаних забезпечити раціональне та продуктивне опрацювання читачем тексту з метою виокремлення і засвоєння необхідної інформації.

\section{ПОШУКО́ВА СИСТЕ́МА}

(англ. search engine) - програмноапаратний комплекс, створений для віднайдення інформаціі у вебенциклопедіях, а також електронних базах даних, створених зокрема й для підготовки енциклопедій.

\section{ПРА́ВКА РЕДА́КТОРСЬКА}

(англ. editor's alteration) - зміна тексту на різних етапах підготовки до видання з метою вдосконалення його змісту, літературної, редакційно-технічної та графічної форм. Внесенню П. р. передує редакторський аналіз: вивчення оригіналу авторсъкого, оцінювання його придатності до друку, за необхідності допомога aвmopy в процесі вдосконалення змісту статті. Основними завданнями П. р. є усунення помилок, пропусків, огріхів, виявлених під час редакторського аналізу і не виправлених у ході авторського доопрацювання; досягнення виразності та ясності формулювань; перевірка фактичного матеріалу; покращення структури, мови і стилю. Основні принципи виправлення тексту: доречність, послідовність (узгодженість), зрозумілість, компактність.
За ступенем і характером змін розрізняють: вичитку - виправлення остаточного (погодженого 3 автором) варіанту тексту або технічних похибок при підготовці перевидань без змін тексту; скорочення - виправлення з метою зменшити текст до потрібного обсягу; оброблення ідейно-смислові, фактичні, композиційні, логічні, стилістичні виправлення без докорінного перетворення тексту; перероблення - глибокі зміни авторського матеріалу, який слугує лише основою для остаточного тексту видання. Наступний після П. р. етап роботи над текстом - коректура.

\section{РЕДАГУВА́ННЯ}

(англ. text editing) - опрацювання редактором оригіналу авторського з метою покращення його змісту та форми. Р. здійснюють відповідно до прийнятих норм і вимог редагування енциклопедичних статей. Головний об'єкт Р. - оригінал авторсъкий (може містити текстову, ілюстраційну, а також аудіо- та відеочастини), другорядні - оригінал видавничий, конструкція та проект видання (перевірка дотримання поліграфічних норм, технічних регламентів тощо). Основні етапи Р. енциклопедичних статей: первинне ознайомлення 3 авторським оригіналом (на цьому етапі здебільшого не вносять правки, але роблять помітки на полях або фіксують побіжні зауваження на окремому аркуші паперу); перевірка фактичного матеріалу (оцінка щодо коректності та достовірності поданих відомостей, змістовного наповнення 
статті); власне Р. матеріалу (виправляють орфографічні, пунктуаційні та стилістичні помилки).

\section{РЕДАГУВА́ННЯ ЗАГА́ЛЬНЕ}

(англ. general text editing) - різновид редагування, мета якого полягає в редакторській допомозі автору або авторсъкому колективу досягнути єдності змісту та форми й уникнути неточностей і розбіжностей. Основними етапами Р. з. є виправлення логічних (порушення порядку викладу, неправильне обгрунтування мотивації дії, наявність неузгодженості думок, понять тощо) і фактологічних (історичних, географічних, друкарських, цифрових та ін.) помилок. Узгодження матеріалу редагованої статті з іншими статтями, представленими в цьому виданні. Зазвичай Р. з. здійснює редактор головний.

\section{РЕДАГУВА́ННЯ КОМП'Ю́TEPHI ЗА́СОБИ}

(англ. text editing tools) - комп'ютерні програми, які дають можливість друкувати, зберігати, редагувати або читати будь-які текстові документи. Їх поділяють на дві основні групи: текстові редактори (програмне забезпечення, за допомогою якого створюють текстові файли без елементів форматування) і текстові процесори (програмне забезпечення, за допомогою якого форматують текст, вставляють у документи графіку та інші не текстові об’єкти тощо). Основні операції редагування за допомогою текстових редакторів: введення алфавітно- цифрової інформації, переміщення по надрукованому тексту, вилучення і вставка символів і рядків. Серед функцій текстових процесорів форматування символів (використання різноманітних шрифтів та накреслень) і абзаців (вирівнювання ширини сторінки й автоматичне перенесення слів), оформлення сторінок (автоматична нумерація, введення колонтитулів і зносок), оформлення документа (автоматична побудова заголовків і показників), перевірка правопису. Сучасні Р. к. з. дозволяють додавати до тексту графічні об'єкти (ілюстрацй̈, діаграми, фотографї).

\section{РЕДАГУВА́ННЯ ЛІТЕРАТУ́РНЕ}

(англ. copy editing) - перевірка, оцінювання та вдосконалення разом із автором літературної форми твору. При написанні енциклопедіü Р. л. застосовують у випадку розподілу праці, коли редактор науковий аналізує та оцінює зміст і наповнення тексту, а редактор літературний - його правописання та мовну стилістику. Часто Р. л. ототожнюють лише із вдосконаленням мовного оформлення, хоча цей процес $€$ лише складовою частиною редакторської праці. Основні етапи Р. л.: аналіз тематичної організацї енциклопедичної статті (визначення головної і побічних тем, робота над тематичними відхиленнями); аналіз композиційної структури, оцінка іï логічності; робота з фактологічним матеріалом, перевірка його точності та достовірності; виявлення й виправлення порушень логіч- 
них зв'язків у тексті; мовна правка; редакційно-технічне опрацювання (робота з текстом оригінал-макету). У процесі Р. л. енциклопедичного контенту редактор літературний повинен намагатися зберегти якнайбільше лексико-морфологічних, синтаксичних особливостей авторського написання, не втрачаючи при цьому риси енциклопедичного жанру.

\section{РЕДАГУВА́ННЯ НАУКО́ВЕ}

(англ. scientific editing) - аналіз i оцінювання ориаіналу авторсько-

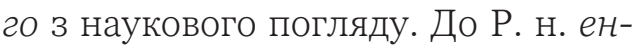
циклопедій залучають провідних фахівців (див.: Редактор науковий) у тій галузі науки, якій присвячено видання, або з якими вони пов'язані. Якщо у процесі підготовки енциклопедї̈ галузевої Р. н. здійснює зазвичай один вузькопрофільний фахівець (або кілька), то до видання енциклопедї загальної чи енциклопедї національної залучають десятки фахівців у різних галузях науки, економіки, культури, літератури й мистецтв, спорту тощо.

\section{РЕДАГУВА́ННЯ ПЕРВИ์ННЕ}

(англ. first editing) - первісне ознайомлення редактора з оригіналом авторським. У процесі Р. п. енциклопедичної статті основну увагу звертають на їі змістове наповнення та відповідність зазначеній тематиці. При цьому за необхідності редактор складає план подальшої спільної роботи разом з автором задля вдосконалення статті згідно з редакційними вимогами.

\section{РЕДАГУВА́ННЯ СПЕЦІА́ЛЬНЕ}

(англ. expert editing) - аналіз та оцінювання ориаіналу авторсъко20 фахівцем (спеціалістом) в тій чи іншій галузі знань. Р. с. застосовують у випадку, коли для редагування текту недостатньо загальних знань редактора, або воно потребує залучення різнопланових фахівців. Приклад Р. с. - підготовка до друку енциклопедичних сmaтей про країни світу, в якій беруть участь фахівці з історії, географї, економіки, політики тощо, при цьому кожен редактор акцентує увагу на тому, у чому є компетентний. Різновиди Р. с.: редагування літературне, редагування наукове, редагування технічне, редагування художне.

\section{РЕДАГУВА́ННЯ ТЕХНÍЧНЕ}

(англ. layout editing) - перевірка матеріального втілення художнього та графічного задуму видання, а також дотримання технічних правил складання оригінал-макету видання і верстки. Основні етапи P. т. енциклопедичних cmameŭ: унормування технічних параметрів складання макету й верстки, контроль шрифтової палітри, контроль за відступами, величиною шрифтів, форматуванням тексту тощо. Р. т. здійснює редактор технічний.

\section{РЕДАГУВА́ННЯ ХУДО́ЖНЄ}

(англ. creative designing) - створення художнього оформлення видання, аналіз та оцінювання ескізів, макетів й оригіналів цього оформлення, 
а також пробних відбитків ілюстрацій та елеметів оформлення. Основні етапи Р. х. енциклопедій: створення проектів художнього та технічного оформлення видання; перегляд авторських оригіналів ілюстрацій i їх оцінювання 3 погляду можливості технологічного переформатування для поліграфічного відтворення; перевірка використаних шрифтів, символів, ілюстрацій, композиції кожної сторінки; підготовка до друку обкладинки. Р. х. здійснює редактор художній.

\section{РЕДа́кТОР}

(англ. editor) - фахівець, який опрацьовує, виправляє та готує до опублікування оригінал авторський. Основні функціональні обов'язки Р. енциклопедичних видань: грунтовне ознайомлення $з$ авторським оригіналом і підготовка аргументованого редакторського висновку; формулювання письмових вимог до автора та співпраця з ним; редагування затвердженого редактором головним авторського оригіналу; узгодження остаточного тексту статті з автором; перевірка та вичитка верстки (з ілюстративним матеріалом). Див. також: Редактор головний, Редактор літературний, Редактор науковий, Редактор технічний, Редактор художній.

\section{РЕДА́КТОР ГОЛОВНИ์Й}

(англ. chief editor) - 1) фахівець, який очолює роботу редакцї або колегї редакційної енциклопедичного видання.
2) Посадова особа, яка керує редакційною роботою у видавництві, що займається енциклопедичною справою.

\section{РЕДА́КТОР ЛІТЕРАТУ́РНИЙ}

(англ. copy editor) - редактор, який здійснює редагування літературне енциклопедичних статей. Іноді Р. л. залучають і до остаточної вичитки тексту енциклопедї.

\section{РЕДА́КТОР НАУКО́ВИЙ}

(англ. scientific editor) - редактор, який здійснює редагування наукове енциклопедичних статей.

\section{РЕДА́ТОР ТЕХНІ́ЧНИЙ}

(англ. layout editor) - редактор, який здійснює редагування технічне енциклопедичних статей та енциклопедї загалом.

\section{РЕДА́КТОР ХУДО́ЖННЙ}

(англ. creative designer) - редактор, який здійснює редагування художнє енциклопедичних статей та енциклопедї загалом. Р. х. може також виконувати функції дизайнера видання, ілюстратора, оформлювача тощо.

\section{РЕДАКЦі́ЙНО-ВИДАВНИ์ЧИЙ ПРОЦЕ́C}

(англ. adition and publishing activity) сукупність послідовних дій працівників видавництва, спрямованих на підготовку й випуск будь-якого енциклопедичного видання. Основні етапи Р.-В. п. у створенні енцикло- 
педій: підготовчий (складання і затвердження сло́вника алфавітного редактором головним або головною колегією редакційною із залученням редакторів наукових, пошук авторів для написання статей, збір оригіналів авторсъких та ілюстрацій), редакційний (редакторське опрацювання отриманих оригіналів, погодження вичитки з авторами), виробничий (перетворення оригінал-макету видання у друковану продукцію), маркетинговий (реклама та інші заходи, пов’язані з продажем видання).

\section{РЕДА́КЦІЯ}

(англ. editorial staff; redaction) - 1) колектив, який готує будь-яке видання до друку.

2) Структурна одиниця видавництва, виокремлена для роботи в певній галузі чи з певними видами публікацій (див.: Редакція літературно-контрольна, Редакція науковогалузева).

3) Опрацювання редактором оригіналу авторсъкого (те саме, що й редагування).

4) Варіант того самого літературного чи музичного твору або його окремої частини.

5) Приміщення, у якому працюють редактори.

\section{РЕДА́КЦІЯ ЛІТЕРАТУ́РНО- КОНТРО́ЛЬНА}

(англ. copy editorial staff) - структурна одиниця видавництва, яку ство- рюють у процесі підготовки до видання енциклопедій універсальних із метою уніфікації форми подання текстів, опрацьованих у галузевих редакціях (див.: Редакція науковогалузева), контролю за дотриманням норм сучасної української літературної мови та вимог енциклопедичного стилю.

\section{РЕДА́КЦІЯ НАУКО́ВО-ГАЛУЗЕ́ВА}

(англ. scientific editorial staff) структурна одиниця видавництва. Р. н.-г. створюють у процесі підготовки до видання енциклопедій універсальних з метою оптимізувати роботу над статтями, що належать до тієї самої або споріднених галузей людської діяльності (науки, освіти, культури, спорту тощо). Основні етапи діяльності Р. н.-Г.: пошук авторів з урахуванням рекомендацій редакторів наукових; замовлення тематичних словників, ї рецензування та редагування (вилучення реєстрових слів подібної тематики, які дублюють одне одного або висвітлюють однакову проблему з різних позицій); редагування, рецензування, загальне обговорення та внутрішньотематичне узгодження отриманих від авторів окремих статей або їхніх циклів; кореляція текстів з ілюстраціями та картами. Після опрацювання у Р. н.-г. матеріал передають до випускової редакції.

\section{РЕєСТРóвЕ СЛо́во}

(англ. catchword) - те саме, що заголовок (див. також: Гасло). 


\section{РЕЦЕНЗЕ́HТ}

(англ. reviewer) - особа, яка здійснює рецензування енциклопедичного видання (зовнішнє рецензування) чи окремої статmі до неї на етапі їі затвердження (внутрішнє рецензування). У процесі підготовки енциклопедї Р. статей може виступати видавничий редактор, редактор науковий і редактор головний, а також, за необхідності, позаштатний висококваліфікований фахівець у певній галузі знань.

\section{РЕЦЕ́НЗІЯ}

(англ. review) - 1) публікація, що містить розгорнутий критичний аналіз надрукованого видання (оприлюднюють у фахових виданнях). $\mathrm{E}$ жанром наукової статті.

2) Документ, у якому зазначено оцінку енциклопедичного видання, підготовленого до друку, та рекомендаційний висновок. Метою Р. $€$ встановлення ступеня готовності видання як завершеної праці. Вирізняють також внутрішню Р., яка стосується окремої енциклопедичної cmammi.

\section{РЕЦЕНЗУВА́ННЯ}

(англ. peer-review) - аналіз та оцінювання рецензентом оригінального енциклопедичного видання або його частини (окремої статті чи їх низки). Застосування Р. в енциклопедичній справі допомагає підібрати відповідний матеріал для опублікування та сприяє загальному підвищенню якості видання. У процесі Р. енциклопедичних статей оцінюють насамперед повноту висвітлення теми $з$ дотриманням загальних вимог енциклопедичного стилю та редакційних стандартів; авторську неупередженість в оцінках і висновках; використання системи логічних обгрунтувань, доказів, посиланъ; застосування наукового апарату видання.

\section{РИСу́нок}

(англ. figure) - графічне зображення будь-якого об'єкта на сторінках енциклопедї. Посилання на Р. у тексті та в підписі під ілюстрацією скорочено позначають словом «Рис.», інколи його курсуючи.

\section{РОЗРЯ́ДКА}

(англ. letter spacing) - маркування слова чи групи слів у тексті шляхом збільшення проміжків між буквами та словами. В енциклопедіях Р. використовують із метою виокремлення підстатті у складі загальної cmammi або окремих елементів складного поняття чи терміна.

\section{РУБРИКА́ЦІЯ СТАТТі́}

(англ. article rubrication) - поділ тексту на пов'язані сурядним чи підрядним зв'язком складові частини (рубрики). Р. с. в енциклопедіях здійснюють за допомогою заголовків, розрядки, нумераціі, шрифтів тощо. При цьому поділ тексту має бути послідовним і сумірним, рубрики мають бути співвіднесені як частини одного цілого. Рубрики, у свою чергу, поділяють на абзаци. 


\section{СКОРО́ЧЕННЯ}

(англ. abbreviation) - подання слів і словосполучень у скороченому вигляді. Застосовують задля оптимізації обсягу видання (кількості сторінок). Види С.: графічні, ініціальні абревіатури, складноскорочені слова, змішані. Ці види, у свою чергу, поділяють на загальноприйняті, спеціальні (характерні для окремих видань або застосовувані у спеціальних текстах, напр., у бібліографічному описі, і зрозумілі без розшифрування) та індивідуальні (запроваджені лише в тексті певного видання і потребують розшифрування, яке подають у списку С.). Вимоги до С.: прийнятність у тексті (що ширшому колу читачів його адресовано, то обмеженіша кількість С.), зрозумілість для читача без розшифрування або з розшифруванням у списку С. (заумови, що таке розшифрування легко запам'ятовується), відсутність омонімії, послідовність і узгодженість у межах усього видання, а не лише однієї статті. С. слів застосовують у бібліографӥ (крім прізвища автора та основного заголовка).

\section{сло́вник}

(англ. thesaurus) - повний реєстр гасел, на основі яких формується корпус енциклопедї. Гасла подають здебільшого з короткою анотацією та із зазначенням обсягу майбутніх cmameŭ. 3 погляду добору реєстру гасел С. утворює зміст енциклопедичного видання, його ідейно-наукову спрямованість. С. забезпечує також створення системи подання статей у масштабі всієї енциклопедіі, виокремлення циклів статей, випрацювання посилань системи. 3 підготовкою С. пов'язане планування структури статті, структури сторінки, розташування бібліографічного, ілюстративного й картографічного матеріалу. Під час створення енциклопедичного видання його С. може поповнюватися новими одиницями.

\section{СЛо́вНИК АЛФАВі́ТНИЙ}

(англ. thesaurus in alphabetical order) словник, укладений за алфавітним принципом. У процесі підготовки енциклопедичних видань спочатку укладають С. а. окремих великих розділів науки (на основі словників тематичних), а потім загальний С. а. видання.

\section{СЛО́ВНИК ТЕМАТИ์чНИЙ}

(англ. thematic thesaurus) - словник, укладений за тематичним принципом. Підготовка енциклопедичного видання зазвичай розпочинається з укладання С. т. для кожної галузі знань, які відображають підпорядкування термінологіі (від загальних до спеціальних термінів). На основі них формують словники алфавітні.

\section{CIIBÁBTOPCTBO}

(англ. coauthoring) - співпраця двох чи більше осіб у написанні спільної cmammi чи всієї енциклопедй, відносини між якими визначено певною угодою, напр., видавничим договором; С. визначає належність двом чи кільком особам авторського права на статтю чи енциклопедичне видання. 
Не є С. надання будь-якої технічної допомоги, а також участі у створенні ідеї чи концепцї̈ твору.

\section{СТАТTя́}

(англ. article) - основна структурна одиниця енциклопедї, що тлумачить реєстрове слово (див. також: Гасло). С. подає найвагоміші відомості про реалію (явище, процес, об'єкт, особу тощо), презентованою реєстровим словом. Характеризується об’єктивністю (науковістю), точністю, авторською неупередженістю, всебічним викладом, простотою подання матеріалу. Структура і обсяг С. визначається редакторською енциклопедӥ концепцією та особливостями власне реаліі. Сукупність С. утворює корпус будь-якої енциклопедії. Становить окремий жанр наукової чи науково-популярної довідкової літератури. Тематично енциклопедичні С. поділяють на блоки: 1) природні утворення, відомості з геології та фізичної географіі, рослинний i тваринний світ, демографія, питання екологіі; 2) геополітичні регіони, держави, землі, адміністративно-територіальні одиниці; 3) нації, етноси, етнічні групи, національні меншини, іхні культури і мови; 4) національні та міжнародні установи - політико-адміністративні, економічні, правові, громадські, освітні, наукові, мистецькі тощо; 5) галузі діяльності - економіка, політика, наука, медицина, виховання, мистецтво та ін.; 6) історичні утворення (цивілізації, держави), історичні періоди (епохи), історичні подіі; 7) сфери свідомості: міфи, релігіі, ідеологї; 8) пізнаваль- на діяльність: науки природничі й гуманітарні, їні найважливіші розділи, філософія та їі основні розділи; 9) найважливіші поняття - повсякденні, наукові, філософські; 10) видатні особистості.

\section{СТАТТЯ์ ÁВТОРСЬКА}

(англ. author's article) - cmammя, написана автором, який є фахівцем у тій галузі знань, до якої належить реєстрове слово енциклопедї (див. також: Гасло). С. а. готується на основі авторитетних достовірних джерел, завдяки яким виклад інформації набуває об'єктивності, точності, всебічності та неупередженості. С. а. подають зазвичай із зазначенням автора.

\section{СТАТТЯ́ БIОГРАФÍЧНА}

(англ. biographical article) - cmammя, що містить визначальні відомості про особу (науковця, культурного діяча, митця, спортсмена, політика тощо). Складається 3 біографічної довідки й представлення фактичних досягнень особи, часто містить коротку характеристику творчого чи наукового доробку.

\section{СТАТТя́ ВІДСИ́ЛЬНА}

(англ. related article) - cmammя, що скеровує читача до іншого реєстрового слова енциклопедіі. Разом із покликанням на іншу статтю може містити елементарне тлумачення.

\section{СТАТТЯ์ КО́МПЛЕКСНА}

(англ. overview article) - cmammя в енциклопедї, підготовлена кілько- 
ма фахівцями, кожен із яких висвітлює зміст реєстрового слова $з$ того аспекту, на якому професійно знається. Зазвичай С. к. представляє складне (багатоаспектне) явище, яке в різних галузях знань має власне значення. Напр., реєстрове слово «людина» містить біологічний, психологічний, філософський, соціальний та ін. аспекти, а отже, стаття про людину вимагає кількох авторів. У написанні статті про державу можуть бути окреслені питання географії, історії, правознавства, соціологіі, демографї, етнографії, культурології, мовознавства тощо. С. к. може бути і статmя біографічна, коли видатна особа досягла успіхів у різних сферах життя, не пов'язаних між собою. С. к. подають із зазначенням авторів кожного розділу чи галузі, іноді в дужках вказуючи, якого саме.

\section{СТАТТя์ ОГЛЯДо́ВА}

(англ. review article) - сmammя, що подає огляд основних проблем, загальних рис, тенденцій, властивих тому поняттю, якому присвячене реєстрове слово енциклопедичного видання. С. о. є одним із піджанрів енциклопедичної статті.

\section{СТАТТЯ́ РЕДАКЦÍЙНА}

(англ. editorial article) - cmammя, написана редакторами видання, а не фахівцями з тієї галузі знань, до якої належить реєстрове слово енциклопедичного видання. С. р. подають без авторства або з ремаркою, що вказує на таку особливість статті.

\section{СТРУКТУ́РA СТАТTÍ}

(англ. article design) - організація текстового й графічного матеріалу cmammi, завдяки чому наповнення cmammi набуває ознак логічної послідовності й цілісності. У С. с. традиційно виділяють такі одиниці (складові частини): заголовок (назва статті), дефініція (тлумачення реєстрового слова), текст (фактичний матеріал), бібліографія, ілюстрація, автор. Проте С. с. може мати іншу організацію залежно від мети, концепції енциклопедичного видання, редакційної політики тощо.

\section{СТРУКТУ́РА СТОРÍНКИ}

(англ. page design) - організація сторінкового матеріалу, полоси й полів. Полоса складається 3 тексту, ілюстрацій, колонцифри, колонтитулу, сигнатури й ін. елементів. Розміри полоси залежать від формату видання і визначаються одиницями типографічної системи вимірювань. Здебільшого С. с. має вигляд прямокутника, оточеного полями різних розмірів. Полосу, з якої починається книга чи іï розділ, називають початковою (може бути зі спуском - незадрукованим проміжком у верхній частині; спуск іноді заповнюють заголовком або орнаментально-декоративними елементами); полосу, яка завершує видання чи його частину, кінцевою; полосу, яка містить тільки ілюстративний матеріал, - ілюстраційною. Поля книги - незадруковані ділянки сторінки навколо полос. Розрізняють корінцеве (внутрішнє), верхнє, зовнішнє і нижнє поля. Роз- 
міри поля залежать від типу видання, площі сторінки і полоси.

\section{CXÉMA CTATTí}

(англ. article format) - послідовність викладу матеріалу, що забезпечує логічний взаємозв'язок та вмотивовану співмірність усіх частин сmammі. Відображає змістове наповнення статті. Існують спільні для всіх енциклопедичних видань С. с., напр., про науковий напрям, наукове поняття, персоналію. Крім цього, кожна редакція залежно від тематики видання напрацьовує власні С. с., напр., про річку, рослину, архітектурний об’єКт тощо.

\section{ТАБЛИ์Ця}

(англ. table) - особлива форма передавання змісту, що відрізняється від суцільного тексту організацією слів і чисел у колонки (графи) й горизонтальні рядки. Між заголовками колонки, рядка та їхнім спільним елементом встановлюють безсловесний, графічний змістовий зв'язок, зрозумілий читачам без переведення у словесну форму. Осн. елементами Т. є нумераційний і тематичний заголовки, головка (заголовок і підзаголовок колонки), прографка, боковик (заголовок рядків), хвіст, колонки і рядки. Осн. вимоги до Т.: логічність і економність побудови, зручність читання. За призначенням їх класифікують на аналітичні (зокрема статистичні; застосовують для висвітлення статистичного матеріалу), проформи (оформляють тільки головку; є зразком для звітних даних), пустографки (графи за- лишаються пустими і доповнюються необхідними даними). За розміром і характером верстання - на клочкові (займають лише частину полоси), поперечні, поздовжні, двійчасті, дво- і багатополосні. За характером оформлення лінійками - закриті (глухі), півзакриті, відкриті. Розгорнена Т. - Т., розміщена на обох сторінках розвороту.

\section{TÉPMIH}

(англ. term) - слово або словосполучення, що позначає чітко окреслене поняття певної галузі науки, техніки, суспільного життя тощо. Основними ознаками Т. є системність, наявність дефініциі, тенденція до однозначності у межах термінології певної галузі, стилістична нейтральність, точність семантики, інформативність.

\section{TOM}

(англ. volume) - 1) самостійно оформлена друкована структурна одиниця енциклопедичного видання. Має свої титул, назву та пагінацію.

2) Збірка декількох окремих випусків багатотомного або продовжуваного видання. Об'єднують випуски в один Т. з метою забезпечити єдність змісту й тематики. Кожен випуск одного Т. має свою внутрішню нумерацію, яку супроводжує наскрізна нумерація всіх випусків.

\section{ТОМ ДОДАТКо́ВИЙ}

(англ. additional volume) - 1) ненумерований том багатотомного видання, що містить довідковий anapam 
видання. Його випускають поза оголошеною кількістю томів.

2) Пронумерований том, виданий як доповнення до попередньо визначеної кількості томів (напр., 11-й додатковий том до словникової частини «Енциклопедії українознавства»). Декілька Т. д. до одного видання можуть мати свою нумерацію.

\section{ТРАНСКРЙПЦІЯ}

(англ. transcription) - спеціальна система письма, яку використовують для точного відтворення слів і текстів іншої мови. Розрізняють три типи Т. Фонетична Т. - спосіб передавання на письмі усної мови з усіма їі звуковими особливостями (кожна літера позначає на письмі той самий звук, а кожен звук передається завжди тією самою літерою). Фонематична Т. передає лише фонемний склад слів і текстів. Практична Т. - запис за допомогою засобів національного алфавіту іншомовних власних назв, термінів та iн. неперекладних слів. Практичну Т. використовують у спеціальній літературі, географічних картах тощо.

\section{ФОТОГРА́ФIЯ}

(англ. photo) - зображення будьчого, отримане внаслідок фотографування. В енциклопедичній справі $\Phi$. використовують як ілюстрациї до cmameŭ, іноді - як видавничий оригінал. Ф. в енциклопедіях бувають різних типів: монохромні (чорно-білі) і кольорові, репортажні (фіксують явища, особи, предмети без втручання фотографа) і постановочні (зрежисовані фотографом) тощо.

\section{ЦИТУВА́ННЯ}

(англ. citation) - дослівне використання фрагментів (уривків) будьякого тексту - цитат. Застосовують на підтвердження думки шляхом посилання на цитоване джерело. Осн. вимогами до цитат є доцільність їх використання і точність відтворення. Цитату беруть у лапки (рідше виділяють видозміною шрифту) та забезпечують посилання на джерело інформації. Іноді при Ц. пропускають слова (пропуск позначають трьома крапками), якщо це не спотворює зміст оригіналу. В енциклопедичних виданнях має мінімальне застосування. 


\title{
ЕНЦИКЛОПЕДИЧНА ХРОНІКА
}

\author{
Тетяна Березюк, Оксана Давиденко \\ Інститут енциклопедичних досліджень НАН Украӥни, \\ київ, Украӥна
}

\section{Тернопедія: тернопільська енциклопедія}

На межі 2017-2018 років з'явилася онлайн-енциклопедія «Тернопільська енциклопедія» (скорочено: «Тернопедія»)1, основною метою якої $€$ розповсюдження відомостей про Тернопільщину та видатних людей цього краю. Онлайн-енциклопедію технічно реалізовано на базі MediaWiki, тому візуально вона нагадує «Вікіпедію». Ї̈ заснував краєзнавець Микола Василечко. На презентації цього енциклопедичного веб-проекту, що відбулася 2 лютого 2018 року в бібліотеці Тернопільського державного медичного університету імені І. Горбачевського, він зауважив, що «Тернопедія» відрізняється від «Вікіпедії», у якій теж міститься чимало інформації про Тернопільщину, передусім за стилем і наповненістю. У «Тернопедії» мають змогу дописувати і редагувати люди під власними іменами (у «Вікіпедії, як відомо, авторство не передбачено); тут також дозволено публікувати оригінальні дослідження, що загалом не властиво енциклопедичним виданням. Нині, станом на кінець 2018 року, енциклопедія містить трохи більше 3,7 тисяч статей. За задумом же автора, їі обсяг складатимуть 50 тисяч статей.

\section{Енциклопедія світових субкультур}

У травні 2018 року на базі MediaWiki було створено онлайнову «Енци-

\footnotetext{
${ }^{1}$ Режим доступу: http://ternopedia.te.ua.
} 
клопедію світових субкультур ${ }^{2}$. Веб-ресурс, що, між іншим, має свідоцтво про державну реєстрацію як засіб масової інформації, підготовлено трьома мовами - українською, російською, англійською. Загальний опис енциклопедії запропоновано на її сайті: «Це унікальний науково-популярний проект, який створено в партнерстві з “Великою українською енциклопедією”. Його мета багатовекторний аналіз світових субкультур. Кожне явище, організація і особистість будуть розглянуті з позиції послідовників, учених і засобів масової інформації».

На думку професора Національного педагогічного університету імені М. Драгоманова Ірини Богачевської, члена редакторської групи цього видання, «Енциклопедія світових субкультур» із погляду особливостей подання матеріалу є цілком інноваційною. Стереотипні енциклопедії не в змозі охопити всю палітру інформації. Наприклад, думки послідовників різних течій і субкультур зазвичай подаються в інтерпретованому варіанті. Традиційно думки академічної науки й засобів масової інформації також знаходяться в різних інформаційних полях. Тут же ми бачимо системний комплексний аналіз, що значно спрощує завдання для дослідників ${ }^{3}$.

\section{Українська фольклористична енциклопедія}

21 вересня 2018 року в рамках національного книжкового ярмарку «Форум видавців у Львові» (Book Forum Lviv) в Музеї етнографії та художнього промислу відбулася презентація «Української фольклористичної енциклопедії, яку підготував колектив фахівців Інституту народознавства НАН України. «Українська фольклористична енциклопедія» - перша енциклопедія про український фольклор. Вона підсумовує досягнення академічної народознавчої науки за 200 років, подаючи інформацію про фольклористів, збірники, часописи, наукові установи, жанри фольклору та про самих персонажів, створених народною традицією. Аналогічні фундаментальні праці мають країни-сусіди, наприклад, Польща («Słownik folklore polskiego»), Білорусь (енциклопедія «Беларускі фальклор»). Донині українська фольклористика в енциклопедичному форматі частково була представлена в «Українській музичній енциклопедії»; відтепер - у власній галузевій енциклопедії.

Керівник цього проекту, науковий редактор і водночас упорядник - доктор філологічних наук, професор Василь Сокіл (завідувач відділу фольклористики Інституту народознавства НАН України). В одній зі своїх публікацій ${ }^{4}$ він зауважував, що ідея створити таку академічну енциклопедію виникла ще

\footnotetext{
2 Режим доступу: http://subcultures.wiki.

3 Луцюк А. Енциклопедія світових субкультур. Навіщо потрібна чергова енциклопедія? // Інформаційне агентство «Центр новин»: електронне видання. 2018. Режим доступу: http://centernews.com.ua/?p=126269.

${ }^{4}$ Сокіл В. Почин української фольклористичної енциклопедії // Народознавчі зошити. 2014. № 3 (117). С. 590-619.
} 
в 1920-х роках - ï ініціювала етнографічна комісія Української академії наук, розпочавши роботу з виписування карток для «Словника українського фольклору» з метою скласти компендіум - повну базу даних українського фольклору. Проте словник тоді так і не уклали.

У 2011 році Мирослава Вовк наголошувала: «Відсутність наукового зводу термінів, понять, які стосуються сфери фольклору й фольклористики, гальмує теоретичні опрацювання багатьох проблем, негативно позначається на підготовці кадрів, видавничій практиці тощо. Об'єктивно назріла потреба створення фольклористичного енциклопедичного словника з висвітленням питань методології наукової галузі, теорії фольклору, історії фольклористики» 5 . Відтак маємо сподівання, що поява «Української фольклористичної енциклопедії» сприятиме поступу вітчизняної фольклористичної науки.

Коли це число «Енциклопедичного вісника України» було підготовлено до друку, в «Літературній Україні» (№45-46, 6 грудня 2018 р.) натрапили на інтерв’ з упорядником і науковим редактором «Української фольклористичної енциклопедії у 2-х томах Миколою Дмитренком. Ї̈ підготовку здійснюють науковці Інституту мистецтвознавства, фольклористики та етнографії імені М. Т. Рильського НАН України. Перший том цієї енциклопедії (А-Л) щойно побачив світ. Отже, відтепер маємо два однакові видання не лише тематично, а й за назвою.

\section{Енциклопедія ЗУНР}

У листопаді 2018 року виповнилося 100 років від дня проголошення Західно-Української Народної Республіки, а в січні 2019 р. - 100-річчя від часу підписання Акту Злуки ЗУНР та УНР. Відповідно до комплексної програми Івано-Франківської області «Відзначення в області 100-річчя створення Західноукраїнської Народної Республіки і 100-річчя Акту Злуки Української Народної Республіки та Західноукраїнської Народної Республіки» ухвалено опублікувати тритомник «Західноукраїнська Народна Республіка 1918-1923. Енциклопедія».

Це видання готують науковці Прикарпатського національного університету імені В. Стефаника. Перший том енциклопедії ЗУНР презентував 31 жовтня 2018 року в Івано-Франківську на Міжнародній науковій конференції «Західно-Українська Народна Республіка: революція, державність, соборність. До 100-річчя утворення ЗУНР» відповідальний редактор - професор Іван Кугутяк. Ректор Прикарпатського національного університету імені

\footnotetext{
${ }^{5}$ Вовк М. Київська академічна фольклористична школа: здобутки і перспективи // Естетика і етика педагогічної дії: Зб. наук. праць. Київ; Полтава, 2011. С. 157.

${ }^{6}$ Рішення Івано-Франківської обласної ради № 816-20/2018 від 02.03.2018 р. Про затвердження обласної комплексної програми «Відзначення в області 100-річчя створення Західноукраїнської Народної Республіки і 100-річчя Акту Злуки Української Народної Республіки та Західноукраїнської Народної Республіки» на 20182019 роки.
} 
В. Стефаника Ігор Цепенда зауважив, що є сподівання, що інші томи будуть завершені невдовзі, і тритомна праця стане повноцінним фундаментом для подальших активних досліджень ЗУНР.

\section{Енциклопедія голодомору}

12 листопада 2018 року в Національному музеї «Меморіал жертв Голодомору» в рамках відзначення 85-х роковин Голодомору-геноциду відбулася презентація «Енциклопедії Голодомору 1932-1933 років в Україні», укладачем якої є доктор історичних наук, професор Василь Марочко. Метою видання укладач назвав необхідність інформувати прийдешні покоління про Голодомор. Енциклопедію видано за сприяння Міністерства культури України.

У передмові до видання, що містить понад тисячу тематичних статей, зазначено: «Енциклопедія ввібрала основні події і явища, узагальнила історіографічні та меморіальні практики. Її завдання - інформувати прийдешні покоління про Голодомор в Україні, не переконувати опонентів, відвертих нігілістів, а правдиво подавати історичні факти, нагадувати про вічні цінності християнського милосердя. Видання не вичерпує тему людського горя, завданого українському народу, змісту і трагедійності самого історичного явища. Автор сподівається на появу регіональних енциклопедичних видань, які стосувалися б кожного району і села, що опинилися в 1932-1933 pр. в епіцентрі Голодомору».

\section{Українська музична енциклопедія}

У 2018 році вийшов друком 5-й том «Української музичної енциклопедії», що висвітлює гасла на літеру «П». Нагадаємо, що «Українська музична енциклопедія» - це галузева енциклопедія, яку від 2006 року готує й друкує Інститут мистецтвознавства, фольклористики та етнології імені М. Т. Рильського НАН України.

Доречно додати, що цього ж року опубліковано книгу «Музичні адреси Києва» - інформаційно-довідкове видання, присвячене київським музикантам, співакам, акторам, які здійснили внесок у розвиток як української, так i світової музичної культури. Видання подає біографічний матеріал у вигляді путівника по Києву; воно прикметне й тим, що містить численні архівні матеріали про персоналії, відгуки про них відомих діячів культури тощо. Автори Віра Горбатюк і Алла Вишнева - на веб-сторінці цього видання зазначають, що задум створити таку працю виник у них ще 1982 року, коли Київ святкував 1500-річний ювілей, відтоді й тривала робота над цим проектом.

\section{Велика українська енциклопедія}

13 грудня 2018 року відбулася презентація онлайн-версії універсальної «Великої української енциклопедії, яку за участі провідних науковців України готує державна наукова установа «Енциклопедичне видавництво». За задумом творців, електронна ВУЕ відрізняється від того, що пропонується

\footnotetext{
${ }^{7}$ Режим доступу: http://knyga1.wixsite.com.
} 
на сторінках друкованої ВУЕ. Електронна ВУЕ - енциклопедичний вебресурс із багатим ілюстративним (світлини, карти, схеми, графіки, діаграми, креслення, малюнки, рисунки), аудіо- та відеоматеріалом, що інтегрується 3 текстом. Веб-сторінка е-ВУE: https://vue.gov.ua.

\section{Українська Вікіпедія}

Станом на кінець листопада 2018 року українська «Вікіпедія містить понад 870 тисяч статей, перебуваючи за цим показником на 16 місці серед «Вікіпедій» іншими мовами світу, на 11 місці серед європейських та на 3-му серед слов'янських. Для порівняння: в кінці листопада 2017 року було опубліковано 750 тисяч статей, отже, енциклопедичний онлайн-ресурс за рік збагатився на 120 тисяч статей. Звісно, за обсягом контенту українська «Вікіпедія» перевершує будь-яке багатотомне видання, однак якість статей у ній часто стає об’єктом критики дослідників. Загалом «Вікіпедії» будь-якою мовою властива спільна проблема, яка поки що немає методів усунення (на відміну від низки інших, наприклад, таких, як інформаційний вандалізм, з яким навчилися боротися) - статті, що мають різні гасла, однак порушують спільні питання, описують те саме явище, реалію, предмет, процес тощо, не узгоджені між собою і за змістом часто суперечать одна одній.

Що стосується безпосередньо української «Вікіпедії», то часто зауважують, що багато статей у ній за глибиною довідковості, повноцінністю контенту поступаються аналогічним статтям, написаним іншими мовами, зокрема й уміщеним у російській «Вікіпедії».

Серед прикметних особливостей української «Вікіпедії назвемо таку: згідно ж з ї даними ${ }^{8}$, енциклопедичний онлайн-ресурс містить багато статей, які у первісному вигляді було скопійовано з «Енциклопедії українознавства», (понад 6 тисяч), «Української радянської енциклопедії,, а також інших енциклопедичних чи довідкових джерел. Можливо, це підвищує якість довідкової інформації у «Вікіпедії», однак суперечить принципам підготовки енциклопедичних видань, науковій етиці тощо, чим «Вікіпедія» вкотре демонструє, що не підходить під визначення терміна «енциклопедія».

\section{ENCYCLOPEDIC NEWSREEL}

\section{Tetiana Bereziuk, Oksana Davydenko NASU Institute of Encyclopedic Resarch, Kyiv, Ukraine}

\footnotetext{
${ }^{8}$ Режим доступу: https://uk.wikipedia.org/wiki/Українська_Вікіпедія.
} 


\section{Енциклопедичний вісник України}

Наукове видання

\section{Число 10}

(Спецвипуск до 100-річчя Національної академії наук України)

Видання містить наукові розвідки з енциклопедистики (серед них - доповіді учасників круглого столу з нагоди100-річчя НАН України «Енциклопедистика в діяльності Національної академії наук України та Наукового товариства імені Шевченка», що відбувся 26 червня 2018 року), матеріали до словника енциклопедичних термінів, запропоновані фахівцями Інституту енциклопедичних досліджень НАН України, а також опис подій 2018 року, пов’язаних з енциклопедичною справою. Для викладачів, аспірантів, студентів та усіх, хто цікавиться проблемами енциклопедистики, біографістики, книгознавства та суміжних наукових напрямів.

За достовірність інформації, що міститься в опублікованих матеріалах, відповідають автори. Редколегія намагається зберегти особливості авторського стилю.

Оригінал-макет виготовив Р. П. Судик

Рекомендовано до друку вченою радою Інституту енциклопедичних досліджень НАН України (протокол № 10 від 30 жовтня 2018 р.).

Формат 70x100/16. Папір офсетний. Друк офсетний. Гарнітура Georgia Pro.

Ум. друк. арк. 12. Обл. вид. арк. 11. Замовлення № 18-45.

Свідоцтво про державну реєстрацію друкованого засобу масової інформації від 12 жовтня 2009 р. (серія КВ № 15829 - 4301P).

Інститут енциклопедичних досліджень НАН України

Свідоцтво про внесення суб’єкта видавничої справи до Державного реєстру видавців, виготівників і розповсюджувачів видавничої продукції ДК № 3484 від 19 травня 2009 р. 